\title{
Generic objectives for community-based education in undergraduate medical programmes: the perspective from developing countries
}

Citation for published version (APA):

Kristina, T. N. (2005). Generic objectives for community-based education in undergraduate medical programmes: the perspective from developing countries. [Doctoral Thesis, Maastricht University]. Diponegoro University Press. https://doi.org/10.26481/dis.20051123tk

Document status and date:

Published: 01/01/2005

DOI:

10.26481/dis.20051123tk

Document Version:

Publisher's PDF, also known as Version of record

Please check the document version of this publication:

- A submitted manuscript is the version of the article upon submission and before peer-review. There can be important differences between the submitted version and the official published version of record.

People interested in the research are advised to contact the author for the final version of the publication, or visit the DOI to the publisher's website.

- The final author version and the galley proof are versions of the publication after peer review.

- The final published version features the final layout of the paper including the volume, issue and page numbers.

Link to publication

\footnotetext{
General rights rights.

- You may freely distribute the URL identifying the publication in the public portal. please follow below link for the End User Agreement:

www.umlib.nl/taverne-license

Take down policy

If you believe that this document breaches copyright please contact us at:

repository@maastrichtuniversity.nl

providing details and we will investigate your claim.
}

Copyright and moral rights for the publications made accessible in the public portal are retained by the authors and/or other copyright owners and it is a condition of accessing publications that users recognise and abide by the legal requirements associated with these

- Users may download and print one copy of any publication from the public portal for the purpose of private study or research.

- You may not further distribute the material or use it for any profit-making activity or commercial gain

If the publication is distributed under the terms of Article $25 \mathrm{fa}$ of the Dutch Copyright Act, indicated by the "Taverne" license above, 


\section{Generic objectives for community-based education in undergraduate medical programmes: the perspective from developing countries}

Tujuan umum pendidikan berbasis masyarakat untuk program dokter: pandangan negara-negara berkembang 
Thesis Maastricht University. The Netherlands

(with summary in Dutch and Indonesian language).

ISBN 979-704-34I-X

(C) 2005. Tri Nur Kristina

Diponegoro University Press. Semarang, Indonesia

Cover design:

"Gunungan" image taken with permission from:

TAMARA \& THE SHADOW THEATRE OF JAVA.

Website: Www.Indonesianshadowplay.com 


\section{Generic objectives for community-based education in undergraduate medical programmes:}

the perspective from developing countries

Tujuan umum pendidikan berbasis masyarakat untuk program dokter: pandangan negara-negara berkembang

\section{Proefschrift}

ter verkriging van de graad van doctor aan de Universiteit Maastricht. op gezag van de Rector Magnificus, Prof. dr. G.P.M.F. Mols volgens het besluit van het College van Decanen. in het openbaar te verdedigen op woensdag. 23 November 2005 om 12.00 uur

door

\section{Tri Nur Kristina}

Geboren op 27 Mei 1959 te Surabaya. Indonesia 


\section{Promotor:}

Prof. dr. C.P.M. van der Vleuten

\section{Co-Promotor:}

Dr. G.D. Majoor

\section{Beoordelingscommissie:}

1. Prof, dr. A.J.J.A. Scherpbier (voorzitter).

2. Prof. dr. J.F.M. Metsemakers.

3. Dr. D.H.J.M. Dolmans

4. Prof. dr. J. De Maeseneer (Universiteit Gent. België)

5. Prof. dr. H.G. Schmidt (Erasmus Universiteit Rotterdam)

The studies presented in this thesis were undertaken within the framework of the World Bank-funded Quality of Undergraduate Education Project at the Faculty of Medicine, Diponegoro University, Semarang, Indonesia. 


\section{Contents}

\section{Acknowledgement}

\section{Chapter I}

Introduction and aims of the thesis.

\section{Chapter 2}

Defining generic objectives for community-based education in undergraduate medical programmes.

(Kristina TN. Majoor GD, Van der Vleuten CPM. Published in Medical Education 2004:38:510-521).

\section{Chapter 3}

A survey validation of generic $\mathrm{CBE}$ objectives for undergraduate medical training.

(Kristina TN, Majoor GD, Van der Vleuten CPM. Submitted to Education for Health).

\section{Chapter 4}

Does CBE come close to what it should be?

A case study from the developing world. Evaluating a programme in action against objectives on paper.

(Kristina TN, Majoor GD, Van der Vleuten CPM. Published in Education for Health 2005;18:194-208) 


\section{Chapter 5}

Does CBE come close to what it should be? A case study from the developing world. Students' opinions.

(Kristina TN, Majoor GD. Van der Vleuten CPM. Submitted to Educalion for Health)

\section{Chapter 6}

Comparison of a community-based education programme executed with and without active community involvement. ...

(Klistina TN. Majoor GD. Van der Vleuten CPM. Medical Education: Accepted with revising)

\section{Chapter 7}

General Discussion.

Chaprer.8

Summary,

Translation in Dutch language

Translation in Indonesian language

Appendix

List of Abbreviation

Pictures of CBE activities in MFDU 


\section{ACKNOWLEDGEMENT}

First of all, thank God that I was given the opportunity to do my PhD studies at Maastricht University, the Netherlands.

I am very grateful to Prof. Cees van der Vleuten, my promotor, for his ever-valuable suggestions, comments, corrections, and encouragement. Many thanks also to his family for their friendship whenever I stayed in Maastricht.

I am also very grateful to my promotor. Dr. Gerard Majoor. His experience as a Network: TUFH board member and his contacts with medical schools in developing countries have greatly facilitated all of my studies. I have learned a lot from him not only in terms of CBE, but also about how to work more carefully and accurately. I also want to thank his wife (Ms Annewies) for her hospitality, which always makes me miss her very much.

Many thanks also to Dr. Pauline Vluggen. Ms Jolanda, Ms Maud. Ms Betsy. Ms Yoka. Ms Marie Louise. and Ms Lilian for their help and friendship.

Thank you so much Ms Mereke for translating my summary into Dutch.

I wish to express my great gratitude to Prof. Dr. Paul Thung, Dr. Martha Thung. Dr. Ferdinand Thung, and to my best friend Dr. Suci Wahyuningsih Thung, who were always there to support and help me during my stays in the Netherlands.

I would also like to thank: Prof. Dr. Kabulrahman. (Dean of Medical Faculty of Diponegoro University. Semarang. Indonesia). Dr. Anggoro DB Sachro, Dr. Anon Surendro, and Prof. Dr. Ign. Riwanto for their support and encouragement. 
I am grateful to Dr. Nurkukuh, Dr. Bambang Hariyana, and Dr. Agus for their support during my study in the area of PHC centre Mlonggo, Jepara, Indonesia. Many thanks also to supervisors in Rural Health Professions Training Centre Salaman and Vice-directors of Municipality Hospitals in Semarang and Jepara for supporting my study.

Special thanks are due to Dr. Helmia and Dr. Hasta for their help in analysing the data, and to Dr. Hidayat and Dr. Handy for their help with the data collection.

I would like to express my gratitude to my students in MFDU for their participation in my studies.

I am especially grateful to my mother (Maemunah). my sister (Dr. Erna Mulati), and my brothers for their support and prayers.

I would like to dedicate this book to those I love the most: my husband (Ir. Moga Narayudha), my daughter (Alfanita Exacty Okterina), and my son (Betharama Wiracandakia), who support me always. 


\section{Chapter 1}

\section{Introduction and aims of the thesis}

\section{INTRODUCTION}

Community-based education (CBE) is usually understood to mean a strategy for facilitating community-orientation of education.' However, the term community-oriented education (COE) is often confused with CBE, and this needs to be explained.

- COE is a characteristic of an institution whose mission, aims, and objectives are determined by the needs of the community within which the institution is located. whose programme adopts a comprehensive rather than a mainly curative approach to health. and whose programme activities indicate commitment to the goal of health for all. ${ }^{2}$

- $C B E$ is defined as a means of achieving educational relevance to community needs and. consequently, of implementing a community-oriented educational programme. ${ }^{3}$ It consists of learning activities that use the community extensively as a learning environment, in which not only students but also teachers, community members, and representatives of other sectors are actively engaged throughout the educational experience. ${ }^{3}$

An educational programme or curriculum can be called communitybased if in the entire curriculum an appropriate number of learning activities is inserted in a variety of primary or secondary health care settings and (particularly in developing countries) within communities. ${ }^{3.4}$ 
Thus, the CBE programme is an approach by which students, already in the early phases of their training, are confronted with the health problems of the communities they are supposed to serve in the future. Such programme emphasizes health promotion and disease prevention in the population."

The general objective of the CBE programme is to expand the students experience in terms of learning, service and research in the community and thereby to improve the health of the community in which the programme is carried out. ${ }^{7}$ As the general purpose of the CBE programmes is to improve the health status of the community, the term "community" in this context could best be defined as "a group of population, or cluster of people within the health planning area identified with a common characteristic and the potential to interact with each other in order to improve health"."

There is a distinct difference in the implementation of CBE programmes between industrialized and developing countries. In industrialized countries the emphasis of CBE is more on the students* attachment to general practices or family practitioners to acquire clinical skills in community settings. ${ }^{9-11}$ However. there are few additional goals such as to experience socio-cultural conditions that impact on the health needs of rural communities; ${ }^{12}$ or working with community organisations to solve community health problems. ${ }^{1.3}$ In developing countries, in addition to those objectives, CBE is implemented to empower the community in improving their health status by establishing partnerships of educational institutions with communities, primary health care, and social agencies and by applying a public health approach. ${ }^{3.14 .15}$ This thesis will focus on CBE for undergraduate medical programmes in the context of developing countries. 


\subsection{Background and rationale of community-based education}

Several forums have encouraged shifting health care and health profession education and particularly undergraduate medical education into community settings and to make medical education more responsive to community health needs. In 1979, the first meeting of The Network of Community-Oriented Educational Institutions for Health Sciences was held. A key aim of this organisation was to build mutual support among member institutions that wished to adapt their curricula to the health needs of the community. ${ }^{16}$ The Edinburgh Declaration, issued by the 1988 World Conference on Medical Education. proposed to modify curriculum content to make it more relevant to national health needs and to enlarge the settings for clinical education by including communities and other non-hospital training sites. ${ }^{17}$ In May 1995 the World Health Assembly passed its resolution WHA 48.8, calling for reorientation of medical education and medical practices for Health for All (HFA), derived from the preceding WHO programme of HFA by the year 2000 through Primary Health Care. ${ }^{1}$ This resolution reiterated that current medical practices should be adapted to better respond to health needs of both individuals and communities.

There are several reasons in favour of implementation of CBE in undergraduate medical programmes. The principal reason is the considerable discrepancy between the types of patients seen by students in teaching hospitals (tertiary care) and the characteristics of patients visiting primary health care facilities. ${ }^{56.19}$ A CBE programme provides students with a patient population representative for the context they will work in as professionals. The use of primary care settings for the CBE programme broadens students" definition of the scope of medical intervention. promotes inter-professional collaboration. alters the power relationship between the (medical) profession and the society it serves, ${ }^{20}$ 
and increases opportunities for understanding of environmental, socioeconomical, psychological, and cultural aspects of health and disease and their implications for care. ${ }^{21}$

The greatest advances in community health status derive from improvements in public health including improvement in standard of living (e.g. sanitation, housing. environmental and occupational safety), promotion of healthy life styles, and education on preventable diseases. The contributions of health professions are not only to provide health care for individuals but also to assist the community to improve conditions influencing (community) health. CBE programmes have the potential to provide public health experiences for medical students by assisting the community to identify their priority health needs and to implement interventions such as health promotion and disease prevention. ${ }^{22}$

Today, health professionals are usually mal-distributed by specialty and geography and inappropriately trained to address the health of the public, particularly the large proportion who are disadvantaged. and this has contributed to the disparity in access to health services. ${ }^{5.6}$ CBE programmes assist students in understanding and handling inequity of health services for medically under-served communities ${ }^{23}$, and also encourage them to become community-oriented specialists. 15.24 .25

Based on the above reasons, a growing number of medical schools all over the world has implemented CBE programmes in their institutions. $^{\%-15.26-31}$ In $1970 \mathrm{CBE}$ was only an isolated example in some curricula, in 1985 it had become established in many curricula, in 2000 it was widely accepted, and is predicted in 2015 as a major focus of medical curricula. ${ }^{32}$ 


\subsection{Learning objectives of community-based education programme}

CBE has been widely accepted as an important innovation in undergraduate medical education, and medical schools may share general goals and similar experiences with respect to $\mathrm{CBE}^{33}$ However, welldefined $\mathrm{CBE}$ objectives are not found in the international literature. $\mathrm{A}$ study that collected objectives from various CBE programmes showed strong heterogeneity among the pertinent sets of objectives. ${ }^{34}$ Another study that looked at nine programmes (in Chile, Cuba, Egypt, India, the Philippines, South Africa, Sudan, Sweden and the United States) found that all programmes described provided a variety of community-based learning experiences. ${ }^{35}$

Also an analysis of the educational reports for Full Member accreditation submitted between 1994 and 2004 by 28 medical school members of the Network: Towards Unity for Health from developing countries, revealed that the objectives of CBE programme vary (Table 1). Participation in public health programmes (93\%) and identification of community health problems and/or risk assessment $(82 \%)$ were most frequently mentioned, followed by management of health problems seen in primary care $(64 \%)$; working in a health team $(57 \%)$; proposing solutions for identified health problems (43\%); and health education to the community (39\%).

Ideally. the definition of learning objectives in the CBE programme should be based on actual health problems of communities in the catchments area of a medical school. ${ }^{4}$ The actual health problems of the community are derived from the assessment of the health needs of the community. This assessment is a systematic approach performed by students and community representatives, and involves epidemiological, qualitative, and comparative methods to describe health problems of a population, to identify inequalities in health and access to health services, 
and to determine priorities for the most effective use of resources. ${ }^{14.36}$ After the identification of a community's priority health problems, students are expected to co-operate with the community to solve these problems and to evaluate the results of their interventions. ${ }^{\text {If }}$ If performed this way, it is reasonable to assert that CBE objectives are based on the essential conditions influencing community health. In addressing these $C B E$ activities, undergraduate medical students may be able to assist the community to implement feasible, affordable and sustainable interventions. Thus, several factors which influence community health status, like e.g. environment, behaviour, education, and health care, could be considered starting points for the definition of CBE objectives. We therefore decided to make an attempt to develop generic CBE objectives for undergraduate medical programmes based on a framework identifying essential factors influencing community health. 
Table 1. Objectives of $\mathrm{CBE}$ activities specified in the reports of medical schools from developing countries submitted to the Network: TUFH

\begin{tabular}{|c|c|}
\hline Objectives & $(28$ schools $)$ \\
\hline \multicolumn{2}{|l|}{ Students should: } \\
\hline Participate in public health programmes & 92.9 \\
\hline Identify community health problems and/or risks & 82.1 \\
\hline Manage of health problems as seen in primary care & 64.3 \\
\hline Work in a health team & 57.1 \\
\hline Propose solutions for identified health problems & 42.8 \\
\hline Provide health education to the community & 39.3 \\
\hline Implement health interventions & 35.7 \\
\hline Manage community health problem & 35.7 \\
\hline Perform research to improve quality of, and/or access to health care & 35.7 \\
\hline Survey environment health & 25.0 \\
\hline Survey, or participate in occupational health & 25.0 \\
\hline Promote personal hygiene and/or sanitation and housing conditions & 25.0 \\
\hline Evaluate the results of thealth interventions & 25.0 \\
\hline Survey life style and health behaviour & 21.4 \\
\hline Promote family health & 21.4 \\
\hline Perform maternal and child health care & 21.4 \\
\hline Assess nutrition status of the community & 21.4 \\
\hline Collaborate with other sectors for community development & 17.9 \\
\hline Be able to manage a health unit & 17.9 \\
\hline Identify cases which need referral & 14.3 \\
\hline Diagnose and manage emergency cases & 14.3 \\
\hline Survey vector prevalence & 14.3 \\
\hline Assess infectious diseases in the community & 14.3 \\
\hline Educate community health workers & 10.7 \\
\hline Survey access to safe water & 10.7 \\
\hline Survey endemic diseases & 10.7 \\
\hline Understand important trends in health care policy & 10.7 \\
\hline Assess or participate in the solution of geriatric problems & 10.7 \\
\hline Plan health education & 7.1 \\
\hline Conduct school children" health programmes & 7.1 \\
\hline Understand the management of the Primary Health Care system & 7.1 \\
\hline Assess chronic and acute diseases & 7.1 \\
\hline Evaluate the results of education & 3.6 \\
\hline $\begin{array}{l}\text { Assess age, sex, genetic predisposition for diseases in given } \\
\text { communities }\end{array}$ & 3.6 \\
\hline
\end{tabular}




\section{AIMS OF THIS THESIS}

The main objective of this thesis is to define and validate generic CBE objectives for undergraduate medical education in developing countries. This effort is unique because generic objectives for such CBE programmes are not available in the literature, and generic objectives will allow comparison of CBE programmes in different settings. This set of generic $C B E$ objectives is intended to be used as reference for the evaluation of existing $C B E$ programmes and as guidance for the implementation of new $C B E$ programmes

The four major research questions addressed in this thesis are:

1. How to develop a framework for the generation of generic CBE objectives for undergraduate medical programmes?

2. What is the perception of medical schools in developing countries toward the developed generic CBE objectives? Will the results of this study yield a validated list of $C B E$ objectives for undergraduate medical training?

3. Can an established method of curriculum evaluation. combined with the generic CBE objectives for under-graduate medical programme, be used as a reference for $C B E$ programme evaluation?

4. What is the impact of a CBE programme matching the generic CBE objectives on students and community? 


\section{Literature Review}
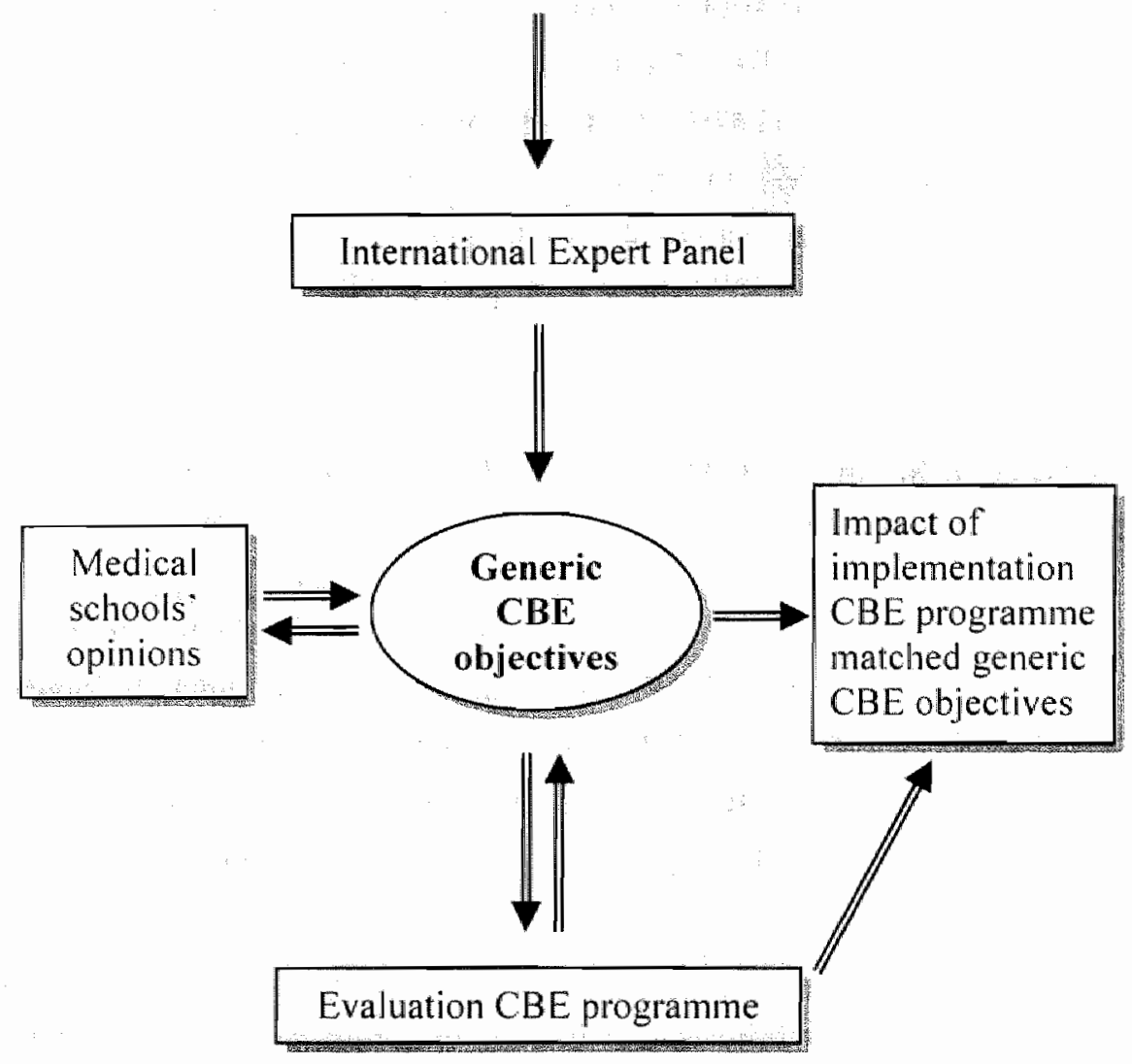

Figure 1.

A framework of generic CBE objectives for undergraduate medical programme 


\subsection{Outline and setting of this thesis}

The contents of this thesis are schematically presented in Figure 1. To define generic CBE objectives for undergraduate medical programmes a logical framework was developed based on literature review and Internet consultation. An international expert panel discussed this framework and the derived generic CBE objectives for face validation. To assure the acceptability of the generic CBE objectives, opinions from medical schools in developing countries were collected to see how much generalisability of the framework might support. Next, the validated set of generic CBE objectives was field-tested. The applicability of the generic $C B E$ objectives was probed in two ways: as a reference to evaluate an existing CBE programme in a medical curriculum and as at reference in the implementation of a $C B E$ programme adjusted to these generic CBE objectives.

The setting for the latter studies was the Medical Faculty of Diponegoro University (MFDU) in Semarang, Central Java, Indonesia. In Indonesia it is compulsory for medical school graduates to work at a Primary Health Care (PHC) centre or at a government secondary hospital for three years before they are permitted to continue with post-graduate specialisation, apply for a job as government officers, or work in a private hospital. ${ }^{37}$ Consequently, any medical school in Indonesia is obliged to adequately prepare its students for community work and hence to include a CBE programme in the curriculum.

The CBE programme at MFDU encompasses two parts and is organised in co-operation with $\mathrm{PHC}$ centres in urban and rural areas, rural health professions training centres, secondary hospitals, the Urban Health Office, and local government authorities. In semester 8 in the fourth year, students study family health problems in an urban area for two weeks. In the final year, students take a ten-week 'CBE clerkship' as 
a part of their clinical rotations to study the management of a $\mathrm{PHC}$ centre, a secondary hospital and the referral system, emergency cases, rural community health problems, and national urban health programmes.

As this study was performed in the context of developing countries, MFDU, which has conducted its CBE programme for over 20 years. was deemed suitable as an example for the evaluation of an existing CBE programme. The result of this evaluation was used as a basis for implementation of a revised CBE programme at MFDU, adjusted to our set of generic CBE objectives.

\subsection{Chapters of this thesis}

\subsubsection{Definition of generic CBE objectives for undergraduate medical programme}

Chapter 2 of this thesis presents a framework for the definition of generic $\mathrm{CBE}$ objectives for undergraduate medical programmes. The method used in this study was based on literature reviews and exploration of Internet sources. First, basic conditions affecting comınunity health were identified. Second, tasks for the students to improve inadequate circumstances were determined. Third, the competencies required to execute those tasks were defined. Finally, educational objectives to develop those competencies were designed. An international panel of experts involved in $\mathrm{CBE}$ at their respective institutions discussed the face validity of the framework and the derived generic CBE objectives.

\subsubsection{External validation of generic CBE objectives}

To examine the acceptability of the list of generic CBE objectives, opinions from a wider audience were collected. In chapter 3, a 
questionnaire containing the framework for the definition of generic $\mathrm{CBE}$ objectives and the list of derived generic CBE objectives was used to acquire perceptions of medical schools in developing countries. Data were acquired from medical schools members of the Network. TUFH and non-Network medical schools randomly taken from developing countries. The result of this study was used to validate the list of generic CBE objectives for undergraduate medical training.

\subsubsection{CBE generic objectives as a reference for CBE programme evaluation}

Programme evaluation is a continuous process to ensure the appropriateness of the implementation of educational programme ${ }^{38}$ The value of programme evaluation is much greater if it is used not only to provide evidence on how well students "learning objectives are being achieved or whether teaching standards are being maintained. but also to identify areas that can be improved and to provide feedback and encouragement for teacher to evolve the curriculum. ${ }^{38}$ Hence, programme evaluation is needed to improve the educational programme rather than to prove. ${ }^{39}$ and this equally applies to CBE programme. Continuous evaluation in the CBE programme is needed not only to show evidence about the value and impact, but also to get feedback to sustain and to improve the programme. 40 The literature on the evaluation of CBE programme indicates a need for better preparation of the intended curriculum to emphasize active involvement of the community and to be concerned with the benefit of CBE programme for the community. ${ }^{+1}$ Concerns have also been expressed about the challenging logistics of dispersed teaching, ${ }^{42}$ issues of remuneration, and conflict with other service commitments. ${ }^{43}$ 
To probe the value of our framework and the set of CBE objectives we evaluated, as a case study, the CBE programme at MFDU using the model of Coles \& Grant (1985), ${ }^{44}$ According to this model, subsequently the curriculum on paper, the curriculum in action, and the curriculun as experienced by the students should be evaluated. The generic CBE objectives developed by us were used as a reference in the analysis of MFDU's CBE programme.

To gather detailed information on various aspects of the $\mathrm{CBE}$ programme, a qualitative study using triangulation of data was applied. i.e. document analysis, direct participatory observations, interviews with faculty members, and focus group discussions with students. In chapter 4. MFDU's CBE programme in action was assessed against it's objectives on paper, and analysed by comparing that programme's objectives to the set of generic CBE objectives. Chapter 5 of this thesis presents the students" opinions about their CBE programme ("experienced curriculum"). The outcomes were used to clarify or strengthen the results from the previous analysis. The evaluation studies presented in chapters 4 and 5 were used to assess how closely MFDU's $\mathrm{CBE}$ curriculum matched the generic $\mathrm{CBE}$ objectives, and to provide suggestions for improvement of the CBE programme at MFDU.

\subsubsection{Implementation of a CBE programme adapted to the set of generic CBE objectives}

An example of a structured approach to the implementation of a CBE programme in the community settings has been described elsewhere. ${ }^{33}$ Taking advantage of this approach we inserted the set of generic CBE objectives. Departing from the results of the evaluation of MFDU's CBE programme (chapter 4 and 5) we redesigned for MFDU part of its CBE programme matching the generic CBE objectives. 
This revised $C B E$ programme was expected to have a different impact on the students and on the community. An experimental study to compare the impact of the revised programme with the traditional CBE programme on both target groups is presented in chapter 6 . A nonblinded, randomised control study was used for the experimental design. Groups of students enrolled in the revised CBE programme were designated experimental groups and those following the unmodified programme conventional groups. The experiment was conducted twice to increase the reliability of data collected.

In chapter 7 the outcomes of our studies will be summarised and discussed.

\section{REFERENCES}

1. Richards R, Fülöp T. Imnovative Schools for Health Personnel Report on ten schools belonging to the Network of Community Oriented Edacational Instinutions for Health Services. Geneva: World Health Organization: 1987.

2. WHO study group report. Increasing the relevance of education for heath professionals. Geneva: World Health Organization:1993.

3. WHO study group report. Community-based Educarion of Health Personnel. Geneva: World Health Organization; 1987.

4. Hamad B. What is community-based education? Evolution, definition and rationale. In: Schmidt HG, Magzoub M, Felleti G. Nooman Z, Vluggen $\mathbb{P}$, eds. Handbook of Community-Based Education: Theon and Practices. Maastricht: Network Publications 2000;1 1-26.

5. Schmidt HG. Preface. In: Schmidt HG, Magzoub M, Felleti G. Nooman Z, Vlluggen P, eds. Handbook of Conmunity-Based Education: Theory and Practices. Maastricht: Network Publications 2000;7-8.

6. Bor D. Position paper. Community-based education for health professionals. http://www.network.unimaas.nl/pp_cbe.htm. April. 2001 
7. Magzoub MEMA, Schmidt HG. A taxonomy of conmunity-based medical education. Academic Medicine 2000,75:699-707.

8. Westbrook LO \& Schultz PR. From theory to practice: Community health nursing in a public health neighbourhood team. Advances in Mursing Science 2000:23:50-61

9. Murray E, Jolly B, Modell M. Can students learn clinical methods in general practice? A randomised crossover trial based on objective structured clinical examinations. British Medical Joumal 1997; 315:920-923

10. Frank SH, Stange KC. Langa D. Workings N. Direct observation of community-based ambulatory encounters involving medical students. The Journal of the American Medical Association 1997: 278:712.

11. Mainhard. MT, Van den Hurk MM, Van de Wiel MW J, Crebolder HFJM, Scherpbier AJJA. Learning in clinical education programme in primary care: the Maastricht Adoption Programme. Medical Education 2004;38:236-243.

12. Dowell A, Crampton P, Parkin C. The first sunrise: An experience of cultural immersion and community health assessment by under-graduate medical students in New Zealand. Medical Edrcation 2001: 35:242-249.

13. Anderson ES, Lennox AI, Petersen SA. Learning from lives: a model for health and social care education in the wider community context. Medical Education 2003;37:59-68.

14. Feletti G, Ja'afar R, Joseph A, Magzoub M, McHarney-Brown C. Omonisi K. Refaat A, Wachs J. Schmidt HG. Implementation of Community-Based Curricula. In: Schmidt HG, Magzoub M. Feletti G. Nooman Z. Vluggen P, eds. Handbook of Community-Based Edwcation: Theory and Practices. Maastricht: Network Publications. 2000;147-199.

15. Omotara BA, Padonu MKO, Bassi AP. Amodu MO. Attitude to communitybased rural posting and specialty preference. Annals of Community-Oriented Education 1992:5:33-40.

16. Schmidt HG, Neufeld VR, Nooman ZM, Ogunbode T. Network of community-oriented educational institutions for the health sciences. Academic Medicine 1991; 66: 259-26।.

17. World Federation for Medical Education. Report of The World Conference on Medical Education. Edinburgh; 1988. 
18. World Health Organization. Doctors for Heasth. A WHO Global Strategy for Changing Medical Education and Medical Practice for Health for All. Geneva: World Health Organization:1996.

19. World Federation for Medical Education. Proceedings of the Mediterranean Regionall Conference. Medical Education 1995;29:1-2.

20. Howe A. Teaching in practice: A qualitative factor analysis of communitybased teaching. Medical Education 2000:34:762-768.

21. Seifer SD, Hermanns K, Lewis J. Introduction. In: Seifer SD. Hermanns K, Lewis J, eds. Creating Community-Responsive Physicians. Washington, USA: American Association for Higher Education 2000;1-8.

22. Bligh J. Tomorrow"s Doctors: extending the role of public health medicine in medical education. Medical Education 2002;36:206-207.

23. Magzoub M, Schmidt HG. Impact of community-based educational programs on graduates: Recent findings and common problems. In: Schmidt $\mathrm{HG}$, Magzoub M. Felleti G, Nooman Z, Vluggen P, eds. Handbook of CommunityBased Education: Theory and Practices. Maastricht: Network Publications; 2000:407-415.

24. Howe $A$, Ives $G$. Does community based experience alter career preference? New evidence from a prospective longitudinal cohort study of undergraduate medical students. Medical Education 2001;35:391-397.

25. Morrison J, Murray TS. Careers preference in medical students: Influence of a new four-week attachment in general practice. British Joumal Generd Practitioners 1996:46:721-725.

26. Grant J, Ramsay A, McBain J. Community hospitals and general practice: extended attachments for medical students. Medical Education 1997;31: 364368 .

27. Waddell RF, Davidson RA. The role of the community in educating medical students: Initial impressions from a new programme. Education for Health 2000; 13:69-76.

28. Sturmberg JP, Reid S, Khadra MH. A longitudinal, patient-centred, integrated curriculum: Facilitating community-based education in a rural clinical school. Education for Health 2002;15:294-304. 
29. Davidson RA Community-based education and problem solving: The community health scholars programme at the University of Florida. Teaching and Learning in Medicine 2002;14:178-181

30. Musal B, Aksakoğlu G, Uçku R. Community-based education programme of Dokuz Eylül School of Medicine. Education for Healh 2003:16:218-221.

31. Khan MZ, Baillie P. An integrated approach through health, education and community development for the developing countries: The Baqai Model. Education for Health 2003;16:75-78.

32. Harden RM. Evolution or revolution and the future of medical education: Replacing the oak tree. Medical Teacher 2000;22:435-442.

33. Magzoub ME. Studies in Commanity-based Education. Program Implementation and Student Assessment at the Faculty of Medicine. University of Gezira, Sudan. Thesis, Maastricht: 1994

34. Engel CE. Community-based/oriented medical education: its objectives and their assessment. Annals of Community-Oriented Educarion 1991:4:139-148.

35. Richards RW. Best Practices in Community-Oriented Health Professions Education: International Exemplars. Education for Healh 2001 :14:357-365

36. Wright J. Development and importance of health needs assessment. British Medical Journal 1998:316:310-313.

37. Indonesian Department of Health. Technical guideline of compulsory work of heallh professional. Jakarta:1999.

38. Morrison, J. ABC of learning and teaching in medicine. Evaluation. British Medical Journal 2003;326:385-387.

39. Rotem A. Evaluation to improve educational programmes. Ammals of Community-Oriented Education 1992;5:135-141.

40. Kalishman S. Evaluating community-based health professions education programs. Education for Health 2002;15: 228-240.

41. William RL, Reid SJ, Myeni C. Pitt L. Solarsh G. Practical skills and valued community outcomes: The next step in community-based education Medical Education 1999;33:730-737.

42. Murray E, Modell M. Community based teaching: the challenges. British Journal General Practitioners 1999;49:395-398. 
43. Wilson A, Fraser R, Mckinley RK, Preston-Whyte E, Wynn A. 3 Undergraduate teaching in the community: Can general practice deliver? British Journal General Practitioners 1996:46:457-460.

44. Coles CR, Grant JG. Curriculum evaluation in medical and health care education. Medical Education 1985; 19:405-422. 


\title{
Chapter 2
}

\section{Defining generic objectives for community-based education in undergraduate medical programmes}

\begin{abstract}
RATIONALE The availability of a framework for the definition of generic objectives for community-based education (CBE) programmes may assist in the rational design of objectives for specific CBE
\end{abstract} programmes.

STRATEGY Factors impacting on community health from the perspective of a developing country were collected. Potential assistance from medical students to communities to improve their health status was determined. Competencies required in students to execute tasks in the community were defined and eventually educational objectives to develop these competencies in the students were established.

METHODS Factors impacting on community health and activities of medical students in CBE programmes were identified by review of literature and Internet resources. Competencies desired for execution of tasks by students and educational objectives to develop these competencies were defined by us and checked against pertinent literature. A draft table representing the 4 elements of the framework was discussed by an international group of experts for external validation.

MAIN OUTCOMES A total of 26 factors impacting on community health were identified and clustered in 5 domains. Twenty-one generic objectives for CBE programmes were defined to develop the required competencies in students. Analogues of each of these 21 objectives were found in at least 1 publication specifying objectives for specific CBE 
Programmes, but none of these publications stated any objective not covered by our list of generic objectives.

CONCLUSION it proved possible to develop a framework to define generic objectives for $\mathrm{CBE}$ programmes. An example was elaborated from the perspective of a medical school in a developing country.

\section{Key learming points}

- It proved possible to construct a framework for the definition of generic objectives for community-based educational programmes for undergraduate medical students in the setting of a developing country.

- Departing from 26 factors impacting on community health, 21 generic objectives for CBE programmes were derived in a 4-step procedure.

- Application of the framework in the setting of industrialised countries may assist in designing objectives for $\mathrm{CBE}$ programmes promoting integration of public health aspects in medical education. 


\section{INTRODUCTION}

Community-oriented education (COE) aims to focus health professions education on the priority health problems of the society in which the educational institution is based. The objectives of COE are supposed to be reflected in the entire curriculum of the educational institution." Community placements within such curricula, organised with the purpose of involving students in studying and addressing the health problems of the communities they are to serve as health professionals, are referred to as community-based education (CBE). ${ }^{2}$ Thus, as a way of implementing a COE programme, CBE is a means of achieving educational relevance to community needs.

Several issues have been discussed in support of making undergraduate medical programmes more community-oriented and more inclusive of $\mathrm{CBE}^{4.5}$ Three of these will be elaborated on here. The first issue concerns the considerable discrepancy between types of patients seen by students in the clinical phase of their studies in the context of the teaching hospital and the characteristics of patients who present to primary health care (PHC) facillities at community level. In addition, because only a small percentage of all patients eventually end up in a tertiary (teaching) hospital, the relevance of undergraduate medical education greatly improves when students are also exposed to health problems in a range of community settings, such as $\mathrm{PHC}$ units, workplaces, schools, households etc. Encountering patients in their own environments illustrates to students the complex interplay between physical, psychological, social and environmental factors in health and illness. ${ }^{7.8}$ The second issue concerns the growing perception that the efficiency of health services may benefit more from inclusion of health promotion and the prevention of diseases (public health) than from unlimited technological advances in curative care. ${ }^{9.10}$ Consequently, 
medical students should also be trained to act as health team managers, advocates for their patients and communities, information specialists, and practitioners who apply social and behavioural sciences. "The third issue relates to the aim of reducing inequity in access to health services. ${ }^{12}$ Community-oriented education and CBE may assist in expanding health services for target communities and eventually motivate graduates to work in health services for medically under-served communities. ${ }^{13}$

Although COE and CBE have been widely accepted as important innovations in undergraduate medical education, little attention has been given to a rational definition of objectives for CBE programmes. A study that collected objectives for various CBE programmes showed strong heterogeneity among these sets of objectives. ${ }^{14}$ The aim of this paper is to present a framework for the definition of generic objectives for CBE programmes. Although in this paper the framework is applied to develop generic objectives for $\mathrm{CBE}$ programmes in the curricula of medical schools in developing countries, the framework can also be applied to $\mathrm{CBE}$ programmes for other health professions and in industrialised countries. There are a variety of settings that may be selected for CBE programmes. In industrialised countries there is a tendency to arrange student placements in community primary care settings such as general practices and primary care surgeries. ${ }^{15}$ In developing countries, often in addition to situations mentioned above, partnerships are established with communities at grassiroots level with the aim of improving their health status by applying a public health approach. ${ }^{5.16}$ As the work for this paper was performed in part to prepare for a revision of the CBE programme at the Faculty of Medicine, Diponegoro University in Semarang. Indonesia, the dominant viewpoint taken in this paper is that of a developing country. 


\section{METHODS}

Four steps were taken to arrive at a draft list of generic objectives for CBE programmes. We set out to define:

1 a set of factors impacting on community health

2 how undergraduate medical students can assist communities to improve their health status.

3 the competencies needed in students to execute such tasks

4 the objectives of $\mathrm{CBE}$ programmes to develop those competencies in the students.

For each step, a literature search covering the years 1966-2003 (April) was undertaken on the Medline and Eric databases. References retrieved from Eric overlapping with those found in Medline were eliminated. Books and papers referred to in the retrieved papers but not identified by our search terms or not indexed in Medline or Eric were added.

In Step 1, resources describing factors impacting on community health and well-being were identified. Literature databases were searched using the search terms 'healthy communities' and 'community health and health determinants". We also performed a Google-assisted search of the Internet. using identical search terms.

In Step 2, possible assistance by undergraduate medical students to communities to address their health needs was inventoried by collecting descriptions of various CBE programmes. For this purpose literature databases were screened using the search terms "students AND community-based education .

In Step 3 we defined the competencies needed in medical students to perform the tasks identified in Step 2. Relevant references were extracted 
from the literature databases using the search terms "competencies AND medical students" and "competencies AND community-based education". Competencies formulated by ws were compared with those in the retrieved literature and the resulting competencies categorised as cognitive and affective competencies and skills.

In Step 4 we designed an educational programme for all the competencies specified in the Step 3 aimed at preparing students for CBE and the objectives to be addressed within a CBE programme. Objectives designed by us were checked against lists of objectives for specific CBE programmes found in references identified by a literature search using the search terms "community-based education and objectives OR goals".

To probe the face validity of the procedure described above and the resulting list of generic objectives for CBE programmes, a draft version of perceived community health needs, student assistance, associated competencies and CBE objectives (Table I) was presented to an international faculty panel involved in CBE at their respective institutions. To prepare for the discussion by this international expert panel, a pilot discussion was held 6 months earlier at Maastricht University with 2 representatives of the Department of General Practice and 1 of the Department of Educational Development and Research.

With I exception the members of the international expert panel were selected to represent institutions applying $\mathrm{CBE}$ in developing countries dispersed over the globe. The panel included single representatives from the University de la Frontera, Temuco, Chili; Pravara Medical Trust, Loni, India; Moi University. Eldoret, Kenya; Mindanao State University, Iligan City, Philippines; the University of Gezira, Wad Medani, Sudan, and the University of New Mexico, Albuquerque, USA. Although the latter institution is not based in a developing country, its CBE programme particularly addresses the health 
of poor indigenous and immigrant communities. ${ }^{17}$ Panel members received the draft version of Table 1,1 week prior to the meeting. In their discussion, held on 24 October 2001 in Londrina, Brazil, the panel addressed the potential usefulness of the procedure applied and the comprehensiveness and relevance of the items produced in each of the 4 steps. Experts shared their views through a moderator to establish the widest range of meaning and interpretation for the topic, using a semi structured question format. ${ }^{18}$ The expert panel discussion was recorded, transcribed verbatim and analysed independently by 2 of the authors (TNK and GDM). The outcomes were used to modify and add items in the draft version of Table $1 .{ }^{19}$ 


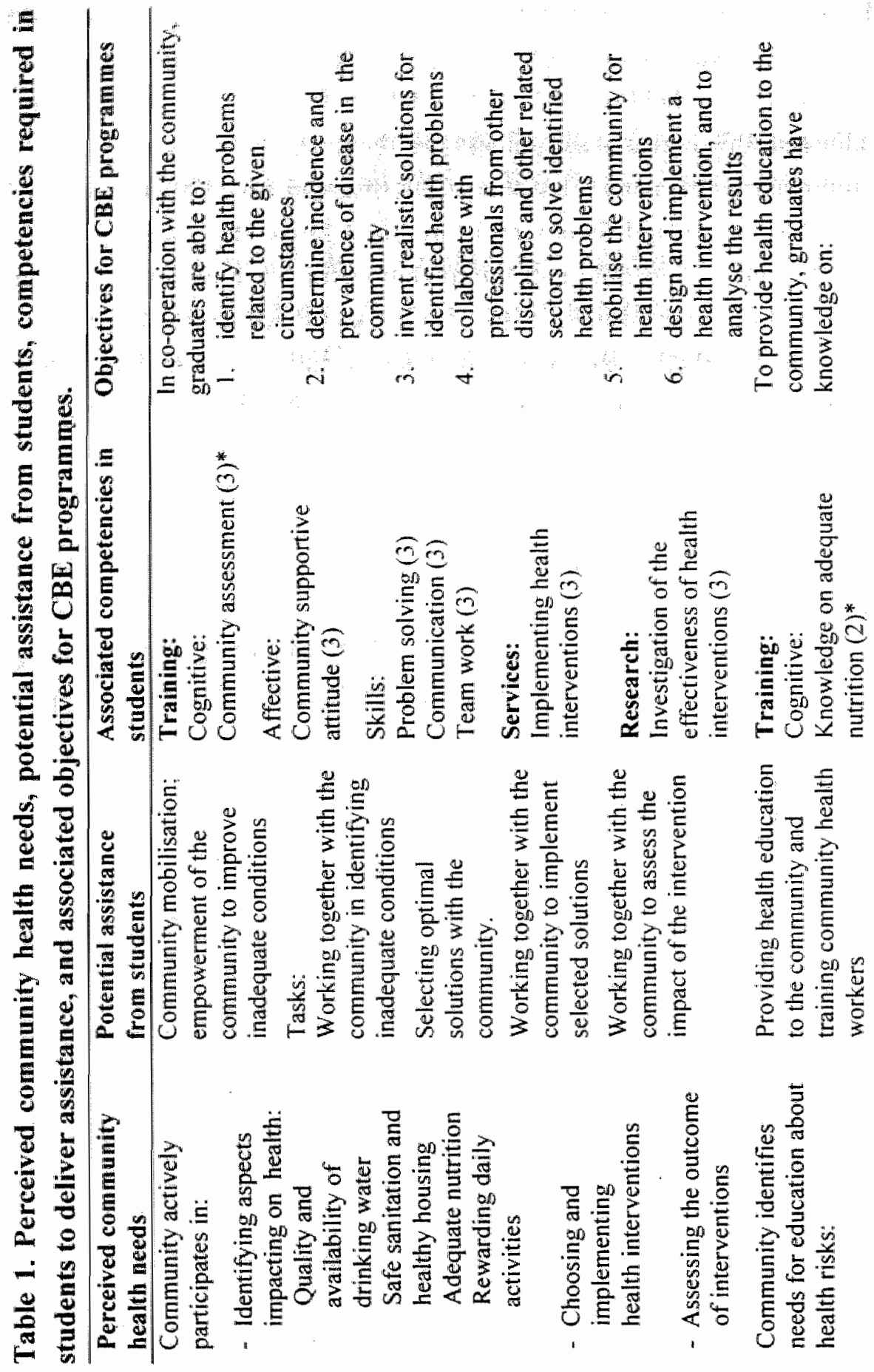




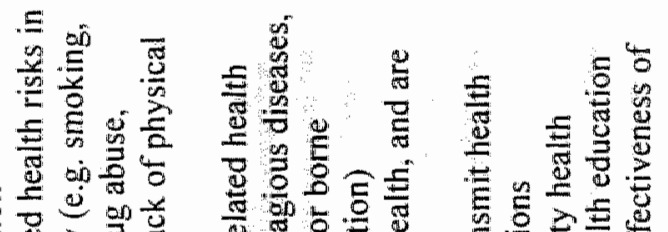

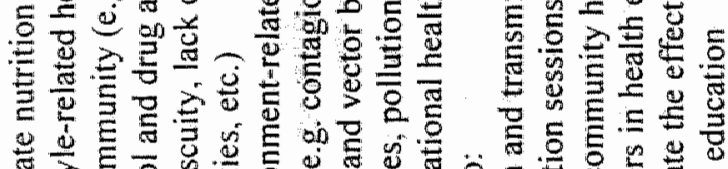

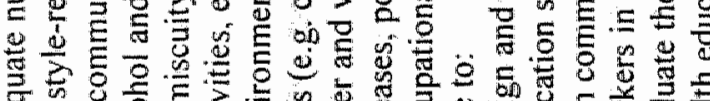

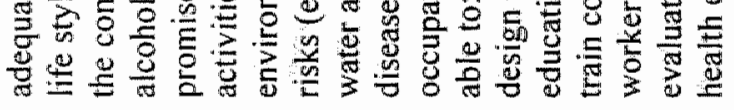
$\therefore \infty \quad \therefore \quad \therefore$ i
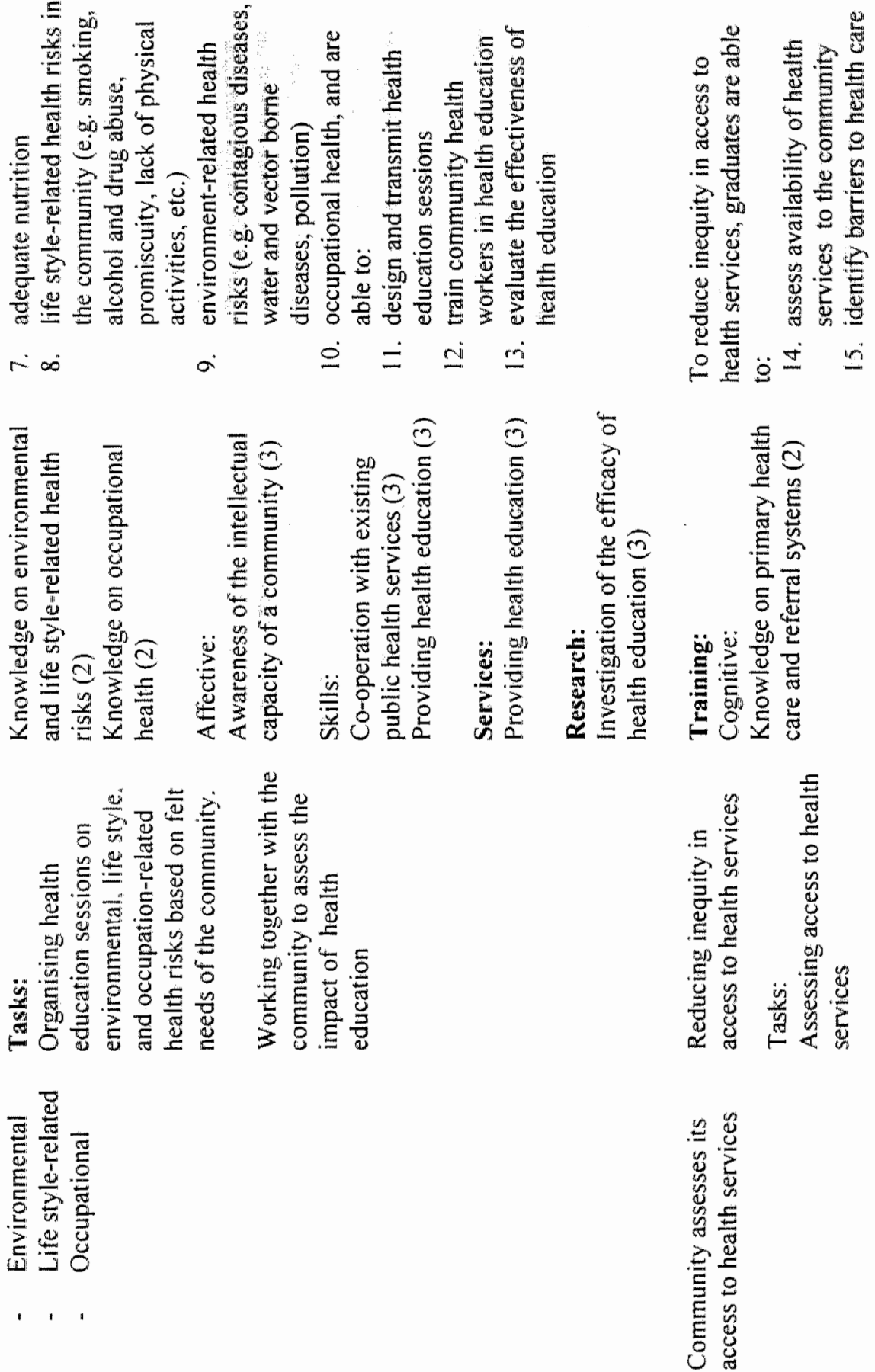

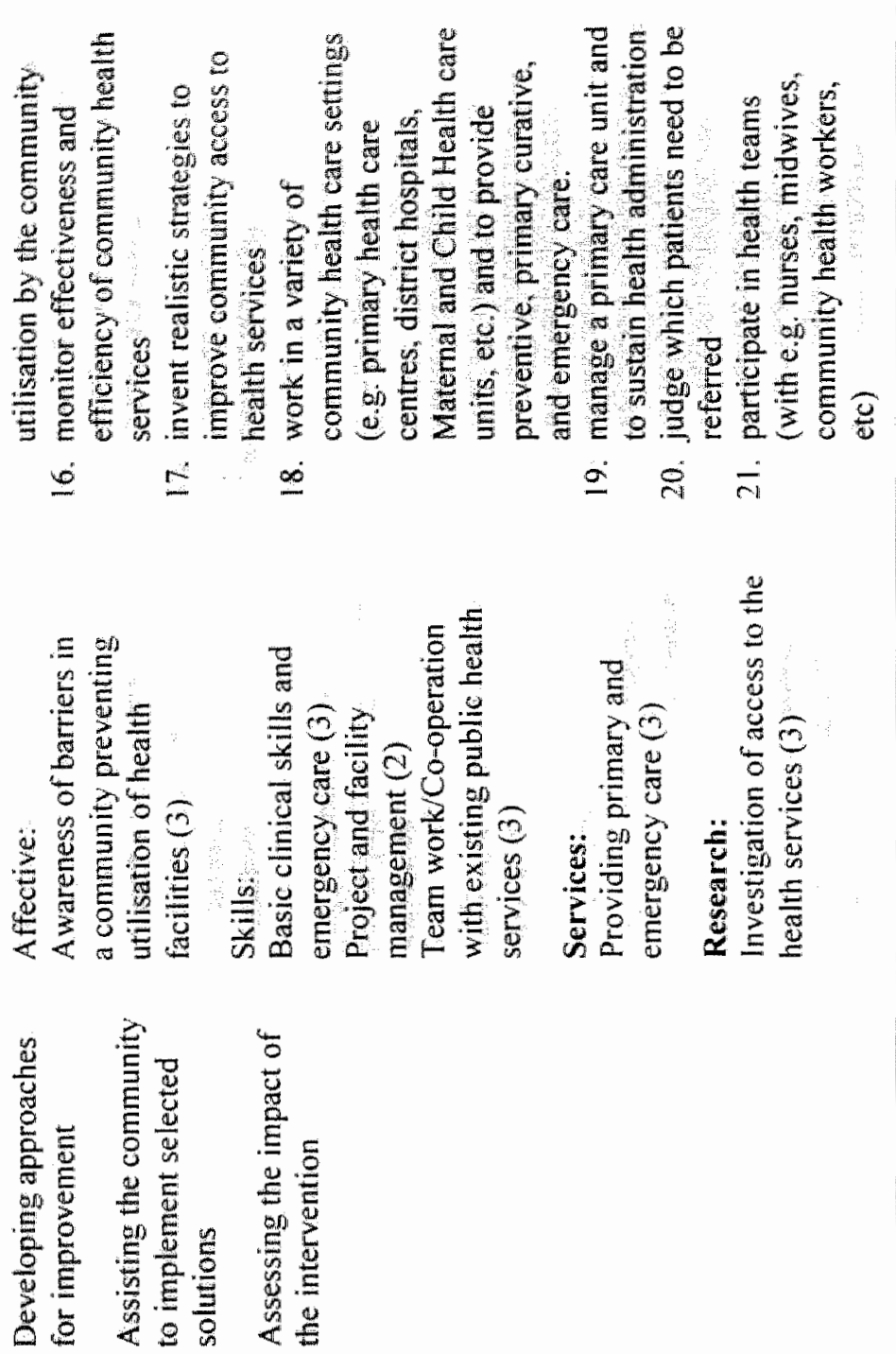


\section{RESULTS}

The results of this study are presented for each of the 4 steps taken in the design of a draft list of generic objectives. Table 1 presents the outcomes of the 4 steps, including modifications adopted from the discussion by the expert panel.

\section{Step 1: Identification of factors impacting on community health}

Literature database searches on factors impacting on community health yielded 153 references from Medline and 20 from Eric. Out of these, 54 papers were found to explicitly specify health determinants or factors impacting on community health and well-being. The Internet search yielded 211 sites, of which 36 met the same requirements. A total of 26 factors were extracted from the resources and clustered into 5 domains: safe environment; rewarding daily activities; adequate nutrition; knowledge about health risks, and access to health care (Table 2). Factors impacting on community health ranged from physical and local (_conditions for basic life support_, e.g. clean air) to socio-cultural and global (environmental conditions, e.g. absence of fear of war). ${ }^{2(1-22}$ From this range we selected 6 conditions impacting on community health that may be improved by the community itself in collaboration with students, such as the availability of safe drinking water, safe sanitation and healthy housing, adequate nutrition, safe working conditions, education on health risks, and access to health services. 
Table 2. Factors influencing community health

Factors influencing community health

Air quality

Environment pollution, e.g. hazardous waste

Quality and availability of drinking water

Safe food

Safe sanitation

Healthy housing, shelter

Absence of fear of war
Domain

Safe environment

Poverty

Unemployment

Rewarding daily activities

Non-adequate nutrition, e.g. unhealthy diet, malnutrition

Adequate nutrition

Insufficient physical activities

Knowledge about health risks

Unsafe sex

Teenage pregnancy

Smoking

Substance abuse, e.g. alcohol, drugs

Water and vector-borne diseases

- related to environment

Safe working conditions

- related to occupation

Awareness of health risks

Prevention care, e.g. immunization

Equity in access to health care

Maternal and child care

School health care

Regular medical \& dental check-ups

- related to life styles

Health insurance

Emergency preparedness, e.g. for road

accidents, violence

Coping with chronic diseases, ageing 
Step 2: Potential assistance from students to improve community health.

A literature search on student activities in CBE programmes yielded 28 references from Medline and 45 from Eric, but only 7 of the references found in Medline (and none from Eric) proved relevant in terms of specifying activities of students in CBE. Medical students in most CBE programmes were found to be involved in providing health services through primary care and by visiting families in their homes. ${ }^{23.24}$ Other activities included co-operation with community members and local health staff in identifying and solving problems affecting community health. ${ }^{25-29}$ Below we present 4 examples from the literature used to inventories activities by students to improve community health. In a CBE programme focused on tuberculosis control, final year students of the University of Natal (Durban, South Africa) conducted community needs assessment. Based on that. a directly observed treatment programme was set up in which students monitored treatment effectiveness by paying home visits. ${ }^{25}$ Students at the University of Gezira in Wad Medani, Sudan were trained to identify and prioritise health as well as other problems and to implement with community participation projects to address those problems. ${ }^{311}$ Students' tasks in the community orientation programme at Christian Medical College in Vellore, India included evaluation of the health status of a community by assessment of chronic diseases, congenital anomalies, and acquired disabilities associated with various diseases. Subsequently, students were assigned to plan, implement and evaluate intervention projects. ${ }^{31}$ Elective studies at Suez Canal University in Ismailia. Egypt were used as an educational vehicle for community research. By carrying out a research project to develop solutions for a health problem in the community, students may indirectly deliver service to the community. ${ }^{32}$ Based on 
these reports; we decided to also include student research activities that indirectly contribute to the improvement of community health.

When exploring the tasks medical students could adopt to assist a community to improve its health status, we discovered a substantial overlap in the types of activities relevant to promote the availability of safe drinking water, safe sanitation and healthy housing, adequate nutrition, and rewarding daily activities. Therefore, the possible student activities addressing these health needs were pooled and considered as 1 cluster in the subsequent steps.

\section{Step 3: Competencies needed in students to assume tasks in CBE.}

We defined the competencies needed for the execution of each of the possible tasks students could assume in CBE. Next we compared our list of competencies to competencies for medical graduates as defined in the literature. Literature searches yielded 104 hits in Medline and 4 in Eric. Of this total of 108 papers, 43 specified competencies required in medical graduates. Most competencies referred to hospital-based clinical care; others more relevant to community health service could be categorised as clinical competencies related to screening for disease and delivery of preventive and primary curative care, communication skills. ability to co-operate in teams with other (health) professionals, and problem-solving skills.

According to a 1987 WHO report, graduates of COE/CBE programmes should have the following professional competencies: provision of preventive care; provision of curative care; health education of the population; management of services; participation in health team work; training other members of the health team, and participation in research activities. ${ }^{5}$ Boelen stated that a doctor must be able to integrate 
preventive, curative, and rehabilitative services, promote healthy lifestyles, reconcile individual and community requirements, and be a team worker. ${ }^{33}$ These competencies were recapitulated in the profile presented for the '5-star doctor', who should be a care provider, decision maker, communicator, community leader and manager. ${ }^{34}$

Analogues of all competencies defined by us were recognised in 1 or more of the references consulted. However, inversely we came across 1 competency mentioned in some references that could not be directly inferred from the students' possible tasks in CBE. This competency pertained to the management of a (small) health facility, which may be particularly relevant in rural areas in some developing countries (see also WHO, $1987^{\circ}$ ). Consequently, this competency was added in relation to 'access to health care'. Following the systematic taxonomy of Harden et al., we sorted the competencies identified as cognitive and affective competencies and skills. ${ }^{35}$ For each of the identified competencies a medical school may wish to set the level the students should have reached on graduation, by, for example, basing them on Miller's levels of competence. ${ }^{36}$ As an example, such labelling has been applied in Table 1.

\section{Step 4: Definition of generic objectives for CBE programmes}

Literature database searches on objectives for $\mathrm{CBE}$ programınes yielded 57 references ( 17 from Medline, 40 from Eric), nine of which specified objectives for specific CBE programmes. ${ }^{14.25 .37-42}$ Analogues of each of the 21 objectives derived by us from the desired competencies defined in Step 3 were found in at least 1 of the references specifying objectives for specific CBE programmes; no objectives were found to be missed by our approach. 


\section{Analysis of the discussion by the international expert panel}

Two questions were consecutively discussed by the international expert panel. The first question explored whether the participants felt it was worthwhile to design a framework for the definition of generic objectives for $\mathrm{CBE}$ programmes. The second question asked for comments on, and additions to, the draft shown in Table 1 (after having received a positive answer to the first question). Participants were unanimous in their support of the attempt to describe a framework for generating generic objectives for CBE programmes. They considered the value of this exercise to lie even more in the approach used than in the resulting example of a set of generic objectives.

About 45 minutes of the 1 -hour session were spent on discussing improvements in, and possible additions to the draft Table 1. Analysis of the transcribed text yielded 4 categories in which remarks and comments could be classified: community health needs; co-operation; generic objectives: and additions. For each of these categories keywords extracted from the transcribed text are presented in Table 3. Our decisions to include or exclude suggested items in the draft Table 1 are discussed below.

With respect to the health needs as perceived by the community. the expert panel suggested distinguishing between "felt" needs and 'actual needs (e.g. those described in the literature as basic health requirements), ${ }^{21.43}$ Because felt needs must be identified in consultation with the community, an item referring to active participation by the community was inserted in Table $\|$ at the top of the column labelled "Perceived community health needs". With respect to defining the assistance that students may lend to the community, the expert panel emphasised the need for students to co-operate with the community. Therefore, mobilising and empowering the community were inserted as 
items in the collumn labelled. 'Potential assistance from students' and most tasks for the students were described as needing to be undertaken in co-operation with the community.

"Socio-economic determinants of health", which was suggested as an additional item, was assumed by us to be covered by 'rewarding daily activities: We argued that problems in this area affecting health would be identified in the dialogue between students and the community. We therefore, neither explicitly included socio-economic determinants of health" nor "income-generating projects" as additional items. We considered the panel's suggestions to add 'organising co-operatives in the community" and 'cross-community co-operation' to be examples of strategies to implement health interventions (compare objectives 3 and 5) and therefore did not add these items to Table 1.

\section{Table 3. Issues raised by the international expert panel}

\begin{tabular}{|c|c|}
\hline Categories & Keywords \\
\hline $\begin{array}{l}\text { Community health } \\
\text { needs }\end{array}$ & $\begin{array}{l}\text { Community and students should work together in } \\
\text { identifying health problems } \\
\text { lnvolve community in setting priorities for the health } \\
\text { agenda } \\
\text { Community empowerment } \\
\text { Community mobillization } \\
\text { Include socio-economic determinants of health } \\
\text { Distinguish felt needs and actual needs }\end{array}$ \\
\hline Co-operation & $\begin{array}{l}\text { Multi professional co-operation. e.g. in health teams } \\
\text { Organising co-operatives in the community } \\
\text { Cross-community co-operation }\end{array}$ \\
\hline Generic objectives & $\begin{array}{l}\text { How to enter in, and integrate with the community } \\
\text { Students as community advocates } \\
\text { Accommodate training, research and service as major } \\
\text { components of CBE programmes }\end{array}$ \\
\hline Additional items & $\begin{array}{l}\text { Occupational health } \\
\text { Chronic diseases } \\
\text { Rehabilitation } \\
\text { Income-generating projects }\end{array}$ \\
\hline
\end{tabular}


The item "how to enter into and integrate with the community" was not included in the list of generic objectives because we felt this skill to be implicit in co-operation with the community as generally emphasised in objectives 1-6. Furthermore, entering the community is also dependent on the quality of the partnership established by the educational institution with the target community and therefore can be considered a condition rather than an objective for a $\mathrm{CBE}$ programme. Following the suggestion by the expert panel, competencies needed in students to assist the community were categorised as those related to training, research and service, respectively. The suggested item 'occupational health' was included as an example of health risks, in health education to be developed by students, and in objective 10 . We felt "chronic diseases" was covered by objectives $14-21$ addressing equity in access to health services. In our view, a possible need for 'rehabilitation services would emerge from assessing available health services (objective 14), and therefore this item was not explicitly added.

\section{DISCUSSION}

This paper presents a framework for the definition of objectives for CBE and elaborates an example focusing on medical schools in developing countries. Both elements of the paper will be discussed consecutively. We feel the strength of the framework presented to define generic objectives for CBE programmes lies in the logical sequence of the 4 steps taken, which yielded objectives traceably rooted in factors impacting on community health. Although the principle of this approach has been recommended earlier (e.g. for the design of COE curriculla ${ }^{3}$ ), in the literature we did not encounter elaborations as detailed as presented here. However, this elaboration has also confronted us with some weaknesses in the procedure. 
Firstly, we cannot be certain that we have identified all factors impacting on community health and well-being. For retrieval of information resources 2 databases and the Internet were explored, using a limited number of search terms. From these references we were directed to literature resources not identified by our search terms or not indexed in the explored databases. Nevertheless, non-indexed resources may be very relevant to this study, such as, for example, the Annals of CommunityOriented Education (issued as of 1988 and continued from 1996 as the journal Education for Health). It must be assumed that we missed some relevant resources but possibly no important factors impacting on. community health, as the 54 papers and 36 Internet sites used showed considerable overlap in the factors presented and eventually yielded just 26 factors. Similar considerations apply to the comprehensiveness of the literature searches performed in Steps 2-4.

Secondly, at some stages in the design of the procedure we clustered items, for instance the factors impacting on community health, into domains, and the possible student activities in CBE programmes to promote the availability of safe drinking water, safe sanitation and healthy housing, adequate nutrition and rewarding daily activities. However, we preferred to provide clear insight into the construction of the framework over the loss of some detail that might possibly result from this clustering.

Thirdly, both the competencies needed in the students to execulte tasks with the community and the objectives for educational programmes to develop those competencies in the students, were initially formulated by us. We are aware that this procedure and the subsequent comparison of these items with inventories of competencies and objectives in the literature may have been influenced by our personal perspectives. To correct for this bias we had our draft framework reviewed by an international expert panel. 
We claim the framework can also apply to CBE programmes for other health professions and in the setting of industrialised countries. For a CBE programme in another health profession, the Step 1 inventory of factors impacting on community health should be composed in tune with the scope of the profession in question. In addition, if the procedure were to be applied in the setting of an industrialised country, the list of factors impacting on community health should be adjusted to the most relevant problems prevailing in those communities. Taking the example of unhealthy diet affecting health in a certain community, students could lend assistance by assessing eating habits in that community, designing interventions such as education in healthy eating, and assessing the impact of such interventions. In current CBE programmes in industrialised countries the emphasis is usually on participation in primary health care, but there is growing support for integration of public health aspects in medical education. This aim calls for the inclusion of student activities in CBE programmes, as described in the above example.

The list of generic objectives for CBE programmes in the setting of developing countries as elaborated in this paper departs from a set of factors impacting on community health and well-being. The exhaustiveness of this list will affect the contents of the subsequent steps. As demonstrated by the expert panel, one may wish to modify or add items and our reasoning behind the adoption or rejection of suggestions may not allways have been unequivocal. On the other hand, the finding that none of the retrieved papers presenting objectives for specific CBE programmes contained objectives essentially different from those derived in our framework supports its reliability.

An important question concerns whether the generic objectives for CBE programmes presented in this study do indeed apply to $\mathrm{CBE}$ programmes for medical students in any developing country. Although 
the discussion by the international expert panel lent support to this assumption, we have planned to further test the relevance of the framework and the set of objectives presented in this paper in a wider circle of medical schools in developing countries.

\section{ACKNOWLEDGEMENTS}

We would like to thank the participants in the pilot group discussion at Maastricht University: Drs Harry Crebolder, Job Metsemakers, and Hetty Snellen-Balendong, and the members of the international expert panel: Drs Fabian Esamai, Arthur Kaufman, Mohi Magzoub, Angelo Manalo, Ashok Patil, and Benjamin Stockins. We gratefully acknowledge the assistance of Dr Jon Martell in the writing of this paper.

\section{ETHICAL APPROVAL}

Ethical approval not required for this study.

\section{REFERENCES}

1. Hamad B. What is community-based education? Evolution, definition and

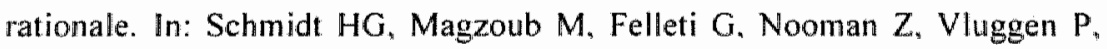
eds. Handbook of Community-Based Education: Theory and Practices. Maastricht: Network Publications 2000:11-26.

2. Habbick BF, Leeder SR. Orienting medical education to community need: A review. Medical Education 1996; 30:163-71.

3. Hamad B. Community-oriented medical education: What is it? Medical Education 1991;25:16-22.

4. Seifer SD, Hermanns K, Lewis J. Introduction. In: Seifer SD, Hermanns K, Lewis J, eds. Creating Community-Responsive Physicians. Washington DC: American Association for Higher Education 2000;1-8.

5. World Health Organisation. Community-Based Education of Health Personnel. [WHO Study Group Report.] Geneva: WHO 1987. 
6. World Federation for Medical Education. Proceedings of the Eastern Mediterranean Regional Conference. Medical Education 1995;29 (1):1-2.

7. Schmidt HG, Neufeld VR, Nooman ZM, Ogunbode T. Network of community-oriented educational institutions for the health sciences. Acudemic Medicine 1991;66:259-261.

8. Evans JR. The "health of the public' approach to medical education. Academic Medicine 1992;67:719-723.

9. Lasker RD \& the Committee on Medicine and Public Health Medicine and Public Health. The Power of Collaboration. New York: New York Academy of Medicine 1997.

10. Bligh J. Tomorrow"s Doctors: extending the role of public health medicine in medical education. Medical Edication 2002;36:206-207.

11. World Federation for Medical Education. Proceedings of the World Summit on Medical Education. Medical Education 1994;28 (1):1-3.

12. Schmidt HG. Preface. In: Schmidt HG, Magzoub M. Felleti G, Nooman Z, Vluggen P, eds. Handhook of Community-Based Education: Theory and Practices: Maastricht: Network Publications 2000:7-8.

13. Magzoub M, Schmidt HG. Impact of community-based educational programmes on graduates: recent findings and common problemsin: Schmidt HG, Magzoub M. Felleti G. Nooman Z, Vluggen P. eds. Handbook of Community-Based Education: Theory and Practices. Maastricht: Network Publications 2000:407-415.

14. Engel CE. Community-based/oriented medical education: Its objectives and their assessment. Annals of Community-Oriented Education $1991 ; 4: 139-148$.

15. Boaden N, Bligh J. Community-Based Medical Education. Towards a Shared Agenda for Learning. London: Arnold 1999;17-28.

16. Magzoub ME, Schmidt HG. A taxonomy of community based medical education. Academic Medicine 2000:75 (7):699-707.

17. Kaufman A, Galbraith $P$, Alfero C, Urbina $C$, Derksen D, Wiese $W$, Contreras $R$, Kalishman $N$. Fostering the health of communities: $A$ unifying mission for the University of New Mexico Health Sciences Center. Academic Medicine 1996;71:432-440.

18. Fontana A, Frey JH. The interview. From structured questions to negatiated text. In: Denzin NK, Lincoln YS, eds. Handbook of Qmalitative Research. Thousand Oaks, California: Sage 1994;645-672. 
19. Frankel RM, Denvers K. Qualitative research: a consumer's guide. Education for Health 2000;3:1 13-123.

20. Badran A. Global overview: state of health education in the world. Medical Education 1995;29 (1):16-23.

21. Shires DB. Ecology of health in communities. In: Shires DB, Hennen BK, Rice DI, eds. Family Medicine. A Guidebook for Practitioners of the Art. New York: McGraw-Hill 1987;207-313.

22. Yassi A, Kjellstrom T, de Kok T, Guidotti TL. Basic Envirommental Health. Oxford: Oxford University Press $2001 ; 14-18$.

23. Mash B, de Villiers $M$. Community-based training in family medicine: $A$ different paradigm. Medical Education 1999;33:725-729.

24. Jones S, Oswald N, Date J, Hinds D. Attitudes of patients to medical student participation: general practice consultations on the Cambridge community based clinical course. Medical Education 1996:30 (1):14-17.

25. Williams RL, Reid SJ, Myeni C. Pitt L. Solarsh G. Practical skills and valued community outcomes: The next step in community-based education. Medical Education 1999;33:730-737.

26. Magzoub ME, Schmidt HG. Testing a causal model of community-based education in the Sudan. Academic Medicine 1998:73:797-802.

27. Barzansky B, Jonas HS, Etzel SI. Educational programmes in US medical schools, 1994-95. JAMA 1995:274:716-722.

28. Hamilton JD, Ogunbode $O$. Medical education in the community: a Nigerian experience. Lancet 1991;338:99-102.

29. Davidson RA. Community-based education and problem solving. The community health scholars programme at the University of Florida: Teaching and Learning in Medicine 2002;14:178-181.

30. Magzoub ME, Hamad B. The struggle for relevance in medical education: experience at the University of Gezira. In: Schmidt HG, Magzoub M, Felleti G, Nooman Z, Vluggen P, eds. Handbook of Community-Based Education: Theory and Practices. Maastricht: Network Publications 2000;241-250.

31. Mendis S. Christian Medical College. In: Richards RW, Sayad J, eds. Addressing the Needs of People: Best Practices in Community-Oriented Health Professions Education. Maastricht: Network Publications 2001;9-21. 
32. Mishriky AM. Practicability of the results of elective studies in the community. Annals of Community-Oriented Education 1994,7:1183-190.

33. Boelen C. Medical education reform: the need for global action. Academic Medicine 1992,67:745-749.

34. World Health Organisation. Doctors for Health. A WHO Global Strategy for Changing Medical Education and Medical Practice for Healih for All. Geneva: WHO 1996.

35. Harden RM, Laidlaw JM, Kerr JS. Mitchell HE. Task based learning: an educational strategy for undergraduate, postgraduate and continuing medical education. Part I. Medical Teacher 1996:18:91-98.

36. Miller GE. The assessment of clinical skills. competence performance. Acadenic Medicine 1990;65:563-567.

37. Magzoub ME. Studies in Community-Based Education. Programme Umplementation and Student Assessment at the Faculty of Medicine, University of Gezira, Sudan. Thesis. Maastricht University 1994.

38. Nazareth I, Mfenyana K. Medical education in the community - the UNITRA experience. Medical Edrcation 1999;33:722-724.

39. Engel CE. Assessment of students' progress and achievement. In: Schmidt HG, Magzoub M, Felleti G, Nooman Z, Vluggen P, eds. Hondbook of Community-Based Edncation: Theory and Practices. Maastricht: Network Publications 2000:221-240.

40. Dowell A, Crampton P, Parkin C. The first sunrise: An experience of cultural immersion and community health needs assessment by undergraduate medical students in New Zealand. Medical Education 2001;35:242-249.

41. Seabrook MA, Lempp H, Wodfield SJ. Extending community involvement in the medical curriculum: Lessons from a case study. Medical Education $1999 ; 33: 838-845$.

42. Anderson ES, Lennox Al, Petersen SA. Learning from lives: A model for health and social care education in the wider community context. Medical Educarion $2003,37: 59-68$.

43. Wolff M, Maurana CA. Building effective community academic partnerships to improve health: a qualitative study of perspectives from communities. Acadenic Medicine 2001;76:166-172. 


\section{Chapter 3}

\section{A survey validation of generic CBE objectives for undergraduate medical training}

\section{Abstract}

INTRODUCTION Recently we developed a framework for the definition of generic $\mathrm{CBE}$ objectives for undergraduate medical programmes, particularly for developing countries. To probe the validity of the set of CBE objectives generated by this approach, opinions from a wider audience were sought.

METHOD We sent questionnaires to 72 medical schools in 36 developing countries. Half of the addressees were randomly drawn from the list of institutional members of The Network: Toward Unity For Health (TUFH), stratified according to developing countries. Another 36 medical schools were randomly drawn from non-Network: TUFH schools from the same country where the selected Network: TUFH addressee was located, or from a neighbouring country.

RESULT A total of 43 medical schools responded (60\% response rate); 31 out of the 36 addressed Network: TUFH members (86\%) and 12 out of 36 addressed non-Network: TUFH schools (33\%). Overall, 39 out of 43 respondents $(91 \%)$ had implemented $\mathrm{CBE}$ in their curricula. Opinions of Network: TUFH and non-Network: TUFH schools on the framework and the generic objectives were not significantly different. Four out of 21 proposed objectives were scored as relevant by less than $75 \%$ of the pooled responders.

CONCLUSION A framework to develop generic CBE objectives and a derived set of 21 objectives were modified based on inputs by 43 medical 
schools residing in developing countries distributed all over the globe. The outcome is a validated set of 20 generic objectives for CBE programmes in developing countries.

\section{INTRODUCTION}

Community-based education (CBE) has become widely accepted as an important innovation in undergraduate medical education. In curricula featuring CBE, students get acquainted with the community early in their studies and working in community settings returns throughout the curriculum. ' Departing from priority health problems jointly identified by community members and students, the latter are encouraged to cooperate with the community to solve these problems and to evaluate the outcomes of their interventions. ${ }^{2}$ Medical schools have implemented CBE programmes for various purposes, for example to enable students to experience the health needs of society and the potentials of communitybased organisations, ${ }^{3}$ to introduce students to the full spectrum of health care; ${ }^{4}$ to advocate public health approaches in assessing the health needs of community; ${ }^{5}$ and to meet health needs of the nation at community and hospital levels." The availability of generic objectives for CBE programmes would assist medical schools with the design of these programmes. Such set of generic CBE objectives could be used to compare with a school's own CBE objectives, e.g. to check whether the most important aspects were covered.

Based on a literature review we recently developed a framework for the definition of generic CBE objectives for undergraduate medical programmes, particularly for developing countries. The framework illustrates the steps taken to develop objectives for CBE departing from factors impacting on community health as perceived by the community; identifying tasks for the students to improve inadequate conditions; 
defining the competencies required to execute those tasks; and eventually designing educational objectives to develop those competencies. This framework was validated by an international panel of experts involved in $\mathrm{CBE}^{7}$ However, to examine the wider acceptability of the generic objectives derived through this framework, opinions from a larger audience were needed. Therefore, the aim of this study was to collect and analyse opinions of medical schools in developing countries on the framework and the derived objectives. Based on the outcomes of this survey we would next transform our preliminary set of generic $\mathrm{CBE}$ objectives into a validated list of generic objectives for CBE in undergraduate medical programmes.

\section{METHODS}

We used purposive sampling to select medical schools in developing countries likely to have implemented CBE programmes. ${ }^{8}$ Developing countries were defined according to World Bank criteria." Although belonging to the high income countries, Bahrain and Israel were included because participating medical schools from these countries featured $\mathrm{CBE}$ programmes comparable to those in developing countries. ${ }^{10.11}$ Thirty-six medical schools residing in 36 different countries were randomly chosen from the list of institutional members of The Network: TUFH, stratified according to developing countries. We assumed Network: TUFH member schools to have integrated CBE in their medical curricula, because one of the goals of the Network: TUFH is to encourage its member institutions to adopt $\mathrm{CBE} .{ }^{12.13}$ To avoid convenience and judgemental sampling bias [a risk due to the fact that one of us (GDM) was a Network: TUFH board member when this study was executed] for each Network: TUFH member school we also randomly selected from the World Directory of Medical Schools, ${ }^{14}$ a non-Network: TUFH school from the same country. If no non-Network: TUFH school was available in the same country, a 
non-Network: TUFH school was selected from a neighbouring country with a similar number of physicians per 100,000 inhabitants. $^{14}$

We distributed questionnaires to a total of 72 medical schools. We promised to raffle 20 copies of a book (i.e. Schmidt et al., 2000) ${ }^{15}$ among all who responded to the questionnaire. The questionnaire presented our provisional list of 21 generic CBE objectives grouped in three themes: 1) solving health problems in collaboration with the community; 2) providing health education to the community; and 3) reducing inequity in access to health services. ${ }^{7}$ In an accompanying letter we explained the purpose of the study and the steps taken in the framework to arrive at generic $C B E$ objectives. Respondents were invited to state their opinion on each individual CBE objective and on the elements in the framework used to arrive at that objective. Respondents were asked to score their opinions on a five-point Likert scale (1=irrelevant; 2=somewhat irrelevant: 3 =neutral; 4 =relevant; $5=$ highly relevant). Additional comments were invited, for which blank space was provided.

\section{Data analysis}

Quantitative data were analysed with SPSS software, version 10. Cronbach"s alpha was calculated to measure internal consistency of items in the questionnaire. ${ }^{16.17}$ We set $75 \%$ as a minimum percentage for general agreement on any particular item. ${ }^{18}$ For this and some other calculations the scores 1 and 2 on the Likert scale were combined to represent 'irrelevant', score 3 was preserved as 'neutral', and scores 4 and 5 were combined to represent 'relevant'. Thus, in this study an item was accepted as relevant when $75 \%$ of the respondents rated this item with a score 4 or 5 . Chi-square test was used to analyse differences between opinions of Network: TUFH members and non-Network schools. Students' t-test was used for comparison of the mean time spans devoted to CBE in Network: TUFH and non-Network: TUFH schools. 
Respondents' additional comments were analysed by coding comparable comments expressed by two or more respondents as key points, then the key points were organised into categories to develop themes. ${ }^{19}$ To consider changes in the provisional set of generic CBE objectives we started from respondents' key points and subsequently checked for each suggestion whether it was supported (or at least not contradicted) by the quantitative data. ${ }^{20}$ Conversely, we reviewed objectives that did not meet the $75 \%$ relevant score in the quantitative data by checking whether these objectives received positive comments from respondents. Lastly, suggestions to change the wording of, or to add some words to any CBE objective were adopted when the suggestion seemed to be worthwhile and did not alter the essence of the particular objective.

\section{RESULTS}

The internal consistency of the questionnaire was satisfactory (Cronbach's alpha for 6 items on 'solving community health problems': 0.81 ; Cronbach's alpha for 7 items on 'providing health education to the community': 0.73 ; and Cronbach's alpha for 8 items on 'reducing inequity in access to health services': 0.85 ).

In total 43 out of 72 addressed medical schools responded to the questionnaire ( $60 \%$ response rate). Thirty-one out of 36 addressed Network: TUFH members responded $(86 \%)$, and 12 out of 36 nonNetwork schools (33\%). There were $2.3 \%$ missing data on 10 items in the questionnaire, $4.6 \%$ on another 5 items, $6.9 \%$ on another 2 items, and $9.3 \%$ on again another 2 items.

Most respondents ( $93 \%$ of Network: TUFH members and $83 \%$ of non-Network schools) had implemented CBE programmes with 
durations ranging from 3-120 weeks. The mean number of CBE weeks implemented by Network: TUFH member schools was 31.2 (standard error of the mean $(S E M)=4.9$ ), and 10.6 for non-Network: TUFH schools ( $\mathrm{SEM}=3.5, p=0.002$ ). Scores of Network. TUFH and nonNetwork: TUFH schools on the relevance of the generic CBE objectives are compared in Table 1. There were no significant differences in the appreciation of the framework and the generic CBE objectives between Network: TUFH and non-Network: TUFH schools. Therefore, data from Network: TUFH and non-Network: TUFH schools were pooled to assess the overall perceived relevance of the framework and the generic $\mathrm{CBE}$ objectives (Table 2).

Apart from one 'neutral' score, all respondents perceived the framework used to develop generic CBE objectives as relevant. The following four CBE objectives were scored as relevant by less than $75 \%$ of the pooled respondents: Graduates 1) have knowledge on occupational health; 2) are able to monitor effectiveness and efficiency of community health services; 3 ) are able to invent realistic strategies to improve community access to health services; and 4) are able to manage a primary care unit and to sustain health administration. 


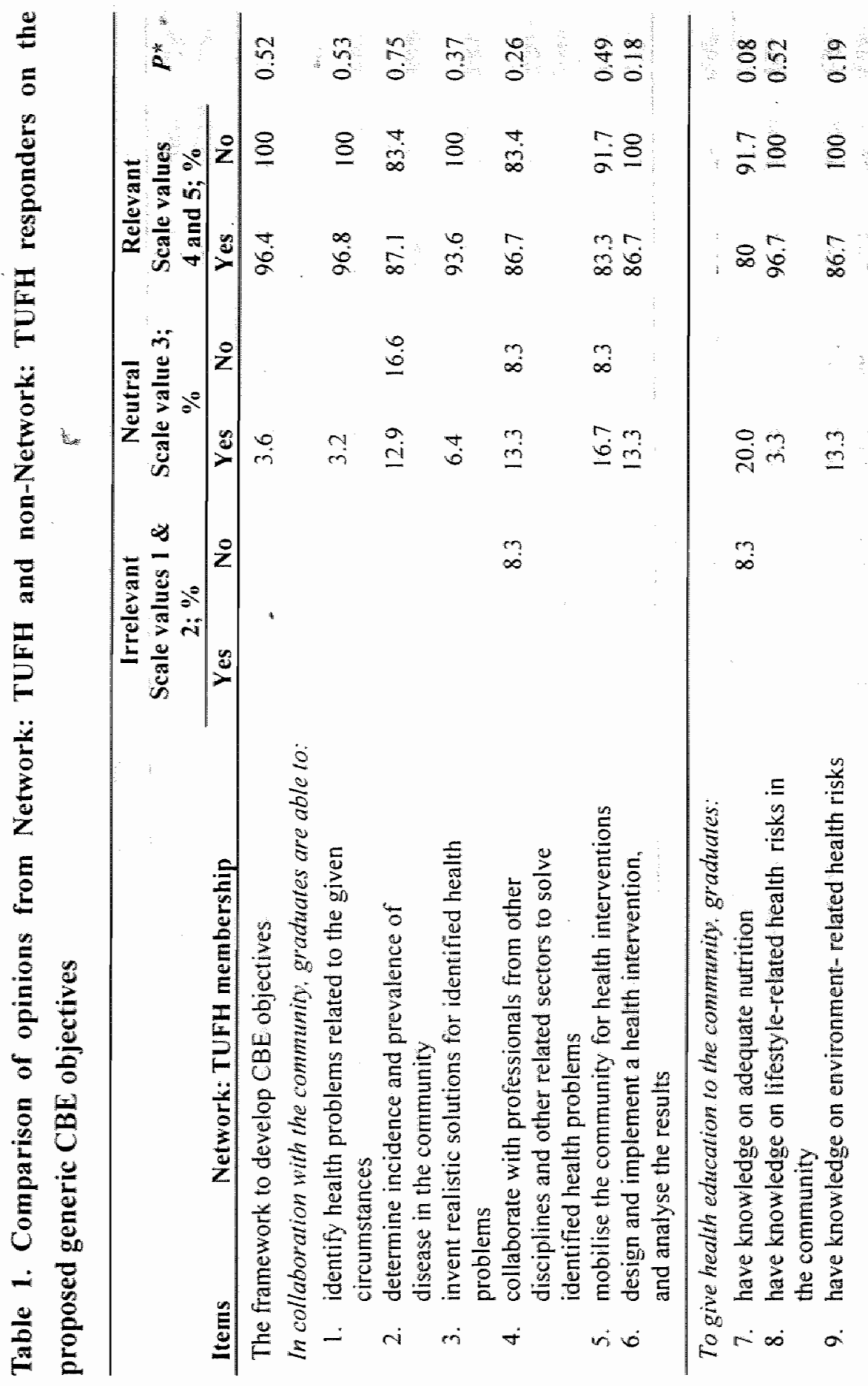




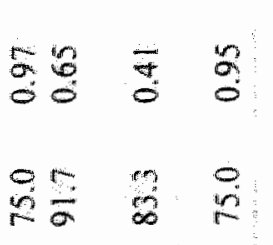

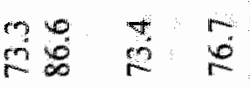

$\underline{00} \underline{0}$

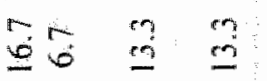

$\infty \quad \infty$

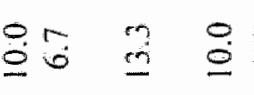

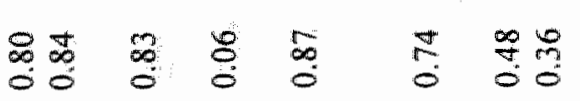

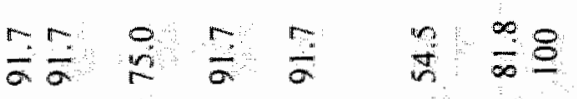

के

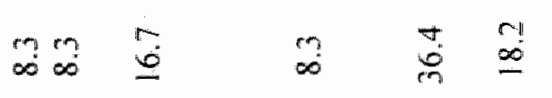

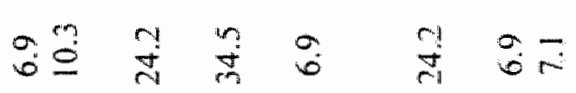

$\infty 2$

$\bar{\sigma}$

$\stackrel{4}{m} \stackrel{9}{m}$<smiles>C[13CH2]</smiles>

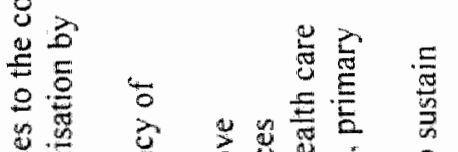

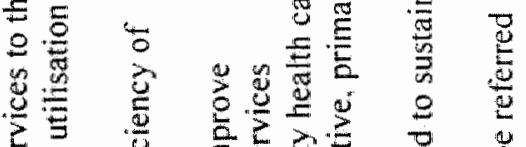

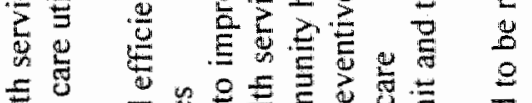

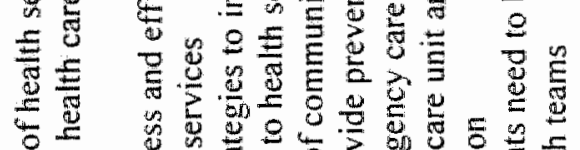

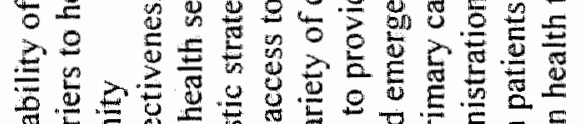
可 क

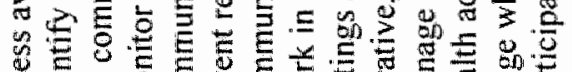

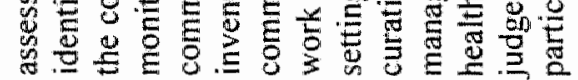

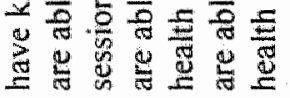
$\dot{a}=\underline{a}$

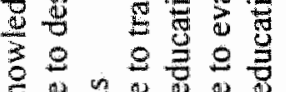

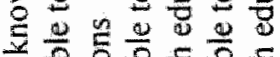

8

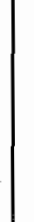




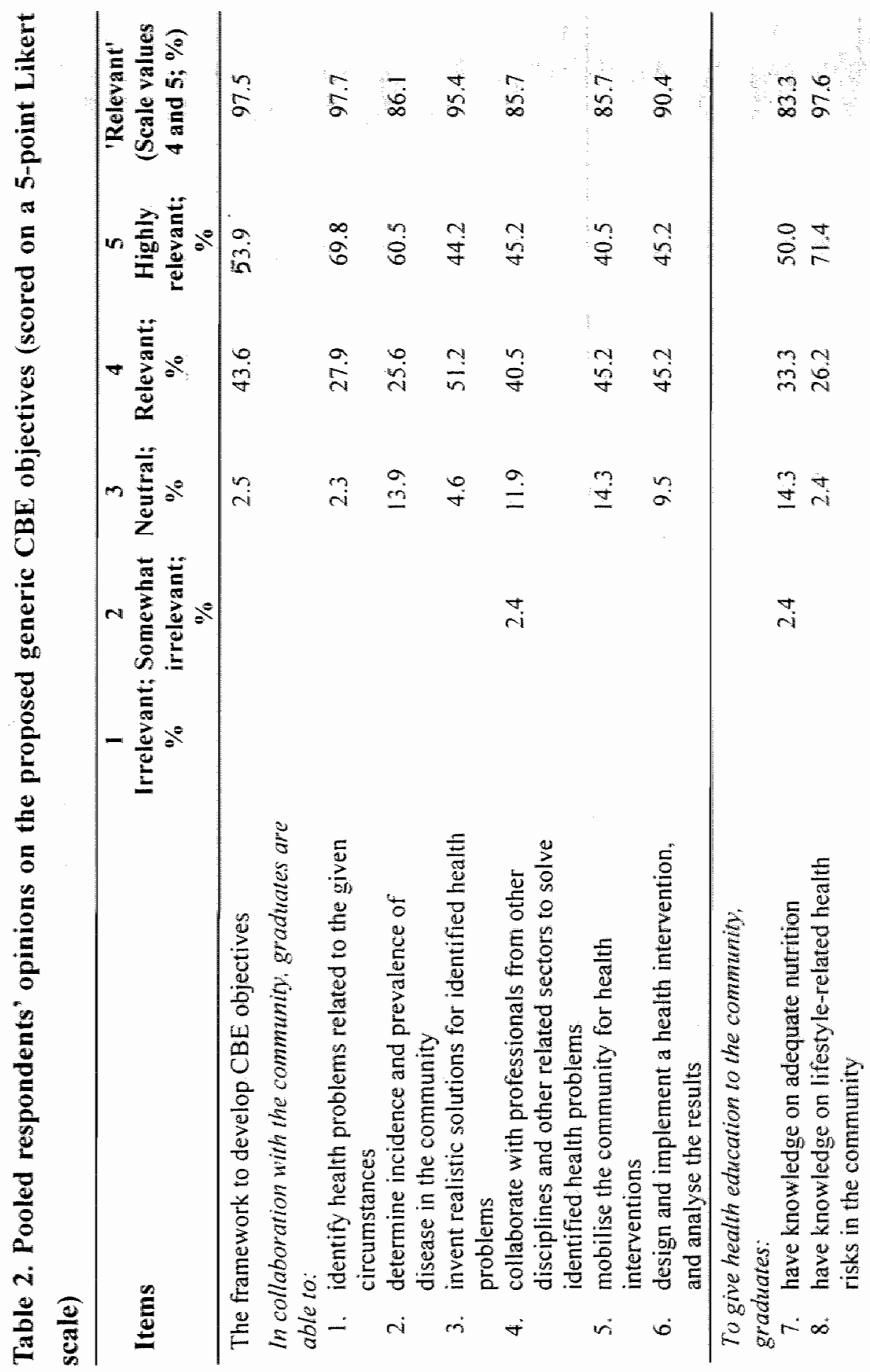




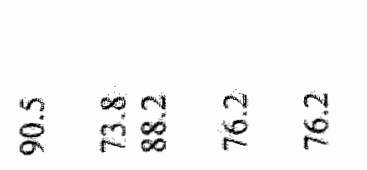

\&

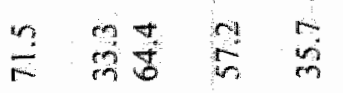

8 वे

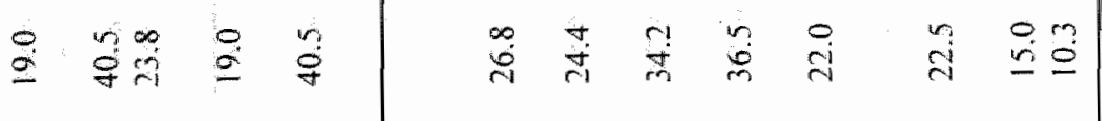

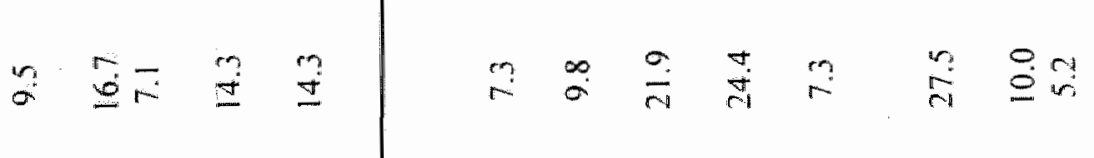

䑤

$\overrightarrow{r i} \quad \vec{a}$

$\therefore i$

is

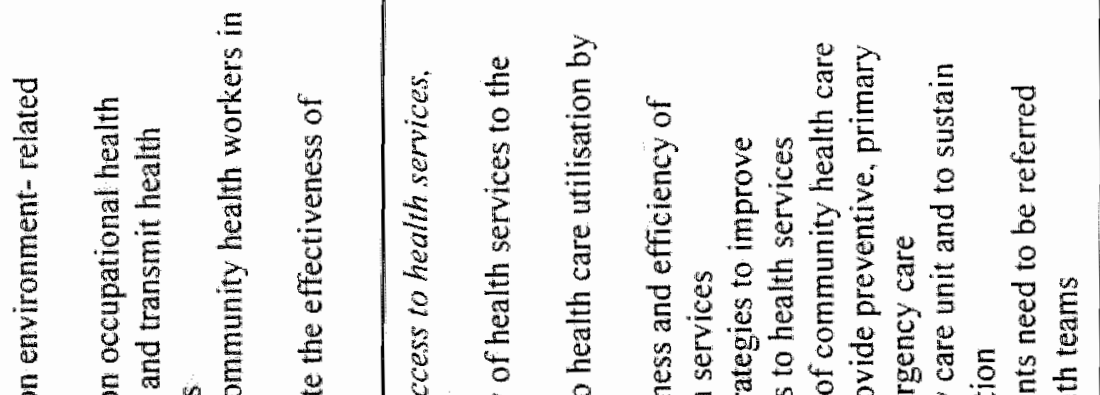

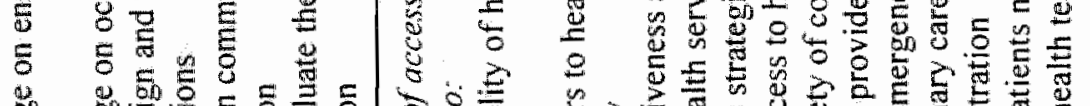

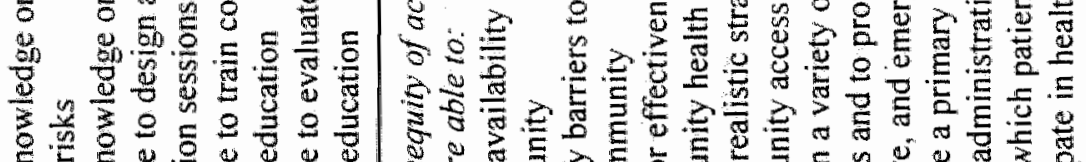
क象

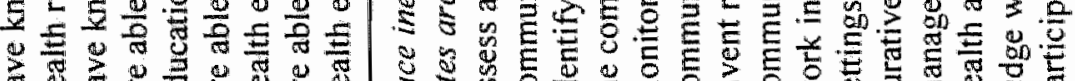

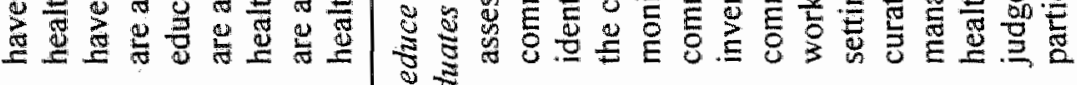

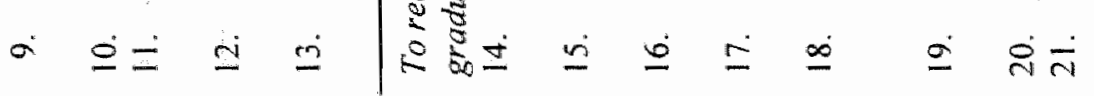


Five themes emerged from the respondents' comments: 1) emphasise partnership and intersectoral collaboration; 2) add specified CBE objectives to the proposed list; 3) positive comments on proposed CBE objectives; 4) criticism on proposed CBE objectives; and 5) objectives on which opinions diverged among respondents (Table 3 ). In addition, some respondents suggested adding and changing the wording of certain objectives.

\section{Digestion of suggestions regarding the preliminary list of generic $C B E$} objectives.

Suggestions to more explicitly insert the concepts of 'partnership between university, local government and community' and 'intersectoral collaboration to mobilise the community for health interventions' were not adopted. Collaboration of students (representing university) and community is covered by objectives 1-6; collaboration with local government by objectives 14-20 (for numbered objectives see Table 4). Intersectoral collaboration is explicitly mentioned in objective 4 .

Respondents' suggestion to add 'Graduates are able to select appropriate teaching aids / media' was not adopted as we considered this skill implicit in the competence addressed by objective 11. Five objectives were considered too ambitious for undergraduate training of medical students. Three out of these five objectives (i.e.: Graduates are able to monitor effectiveness and efficiency of community health services; to invent realistic strategies to improve community access to health services; and to manage a primary care unit and to sustain health administration) were scored as relevant by less than $75 \%$ of the pooled respondents. The latter objective was also frequentlly criticised in added comments. Hence, based on the qualitative and quantitative data, the objective pertaining to management of a primary care unit and 
sustainment of health administration was deleted. We decided not to delete the former two objectives since some respondents also made positive comments about these objectives (Table 3).

We adopted the essence of the suggestion to add 'Graduates understand government health policy'. Therefore, objective 4 was expanded by adding 'with consideration of government health policy'. The suggestion to include 'Graduates empower the community' was adopted in the framework used to derive generic CBE objectives. The issue was inserted on top of the column specifying 'Potential assistance from students' rather than adding it as a separate objective. The essence of the suggestion to add: "Graduates have knowledge on socio-cultural conditions related to health" was inserted in objective 2. We also accepted to add 'community awareness about existing health services' by changing objective 15: 'Graduates are able to identify barriers to health care utilisation by the community" to 'Graduates are able to determine health care utilisation by the community and community attitude to available health services".

We retained objective 10: 'Graduates have knowledge on occupational health although scored as relevant by only $73.8 \%$ of the respondents, because there were positive comments from three respondents on this objective and no negative comments.

Finally, we added and changed the wording of some objectives according to suggestions by respondents, e.g. by adding 'and to solicit the community's effort to develop solutions' to objective 3: 'Graduates are able to design realistic solutions for identified health problems'; and by changing 'invent' used in objective 17 to 'design".

The procedure described above yielded the validated list of generic objectives for CBE presented in Table 4. 


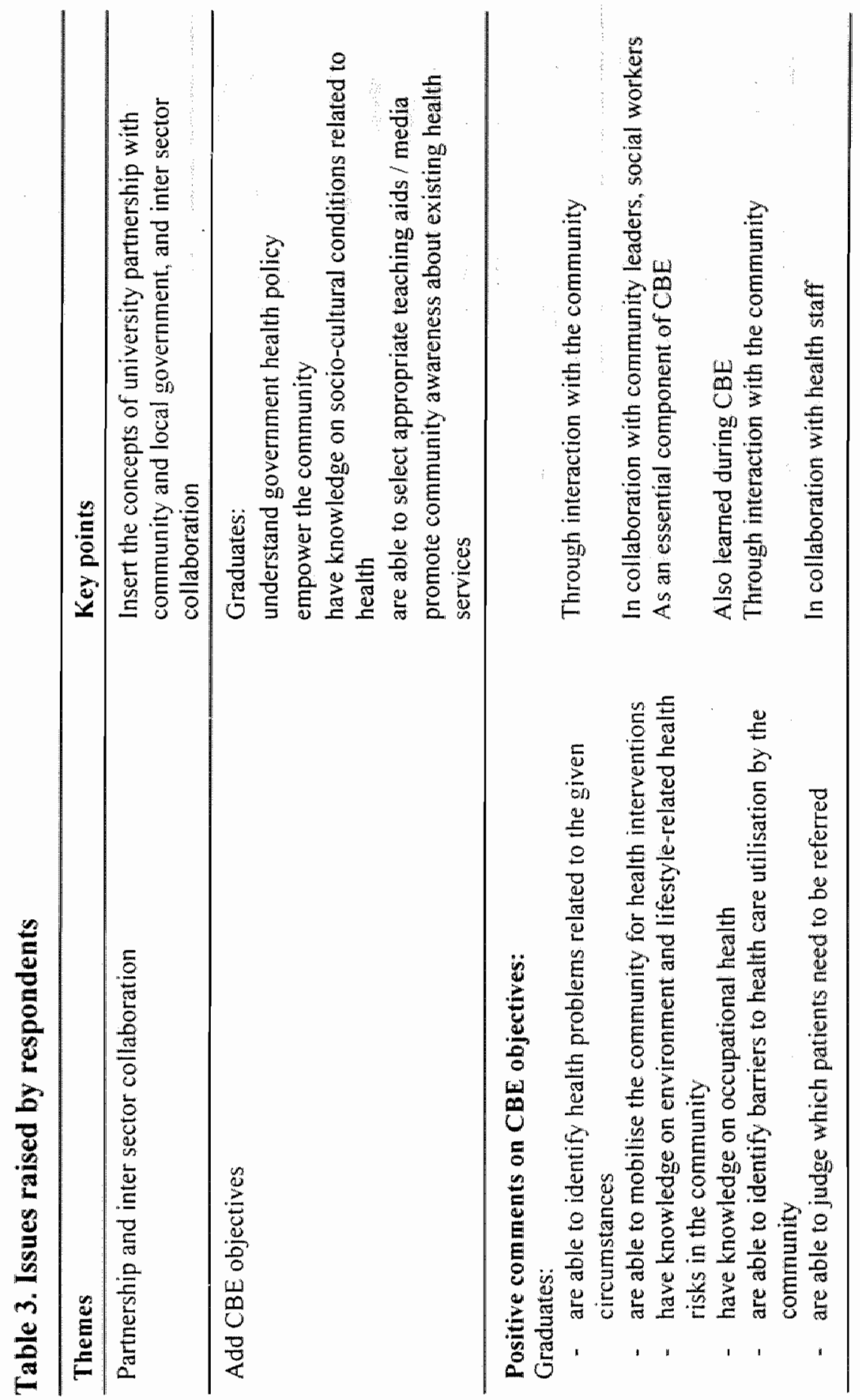




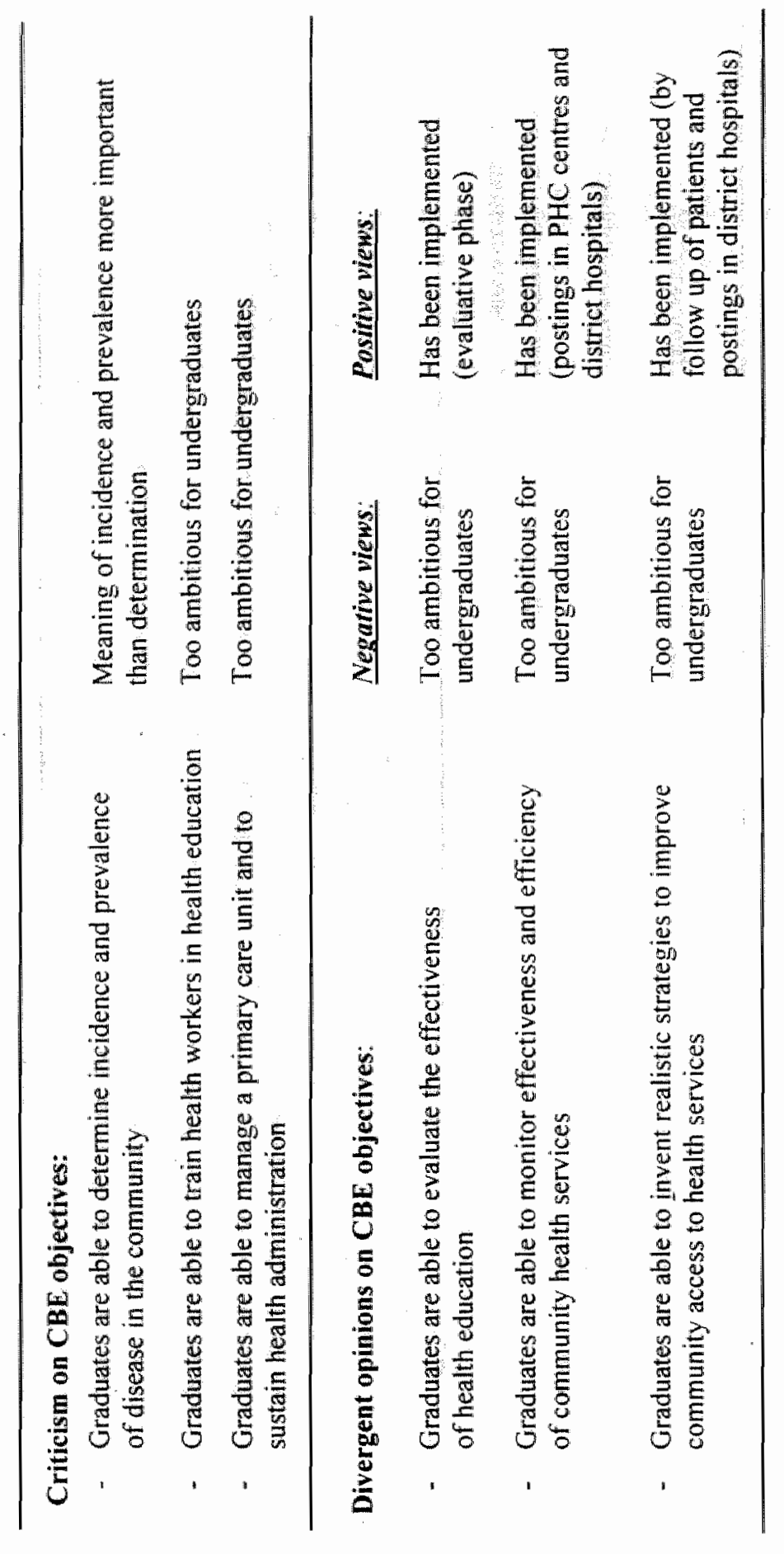




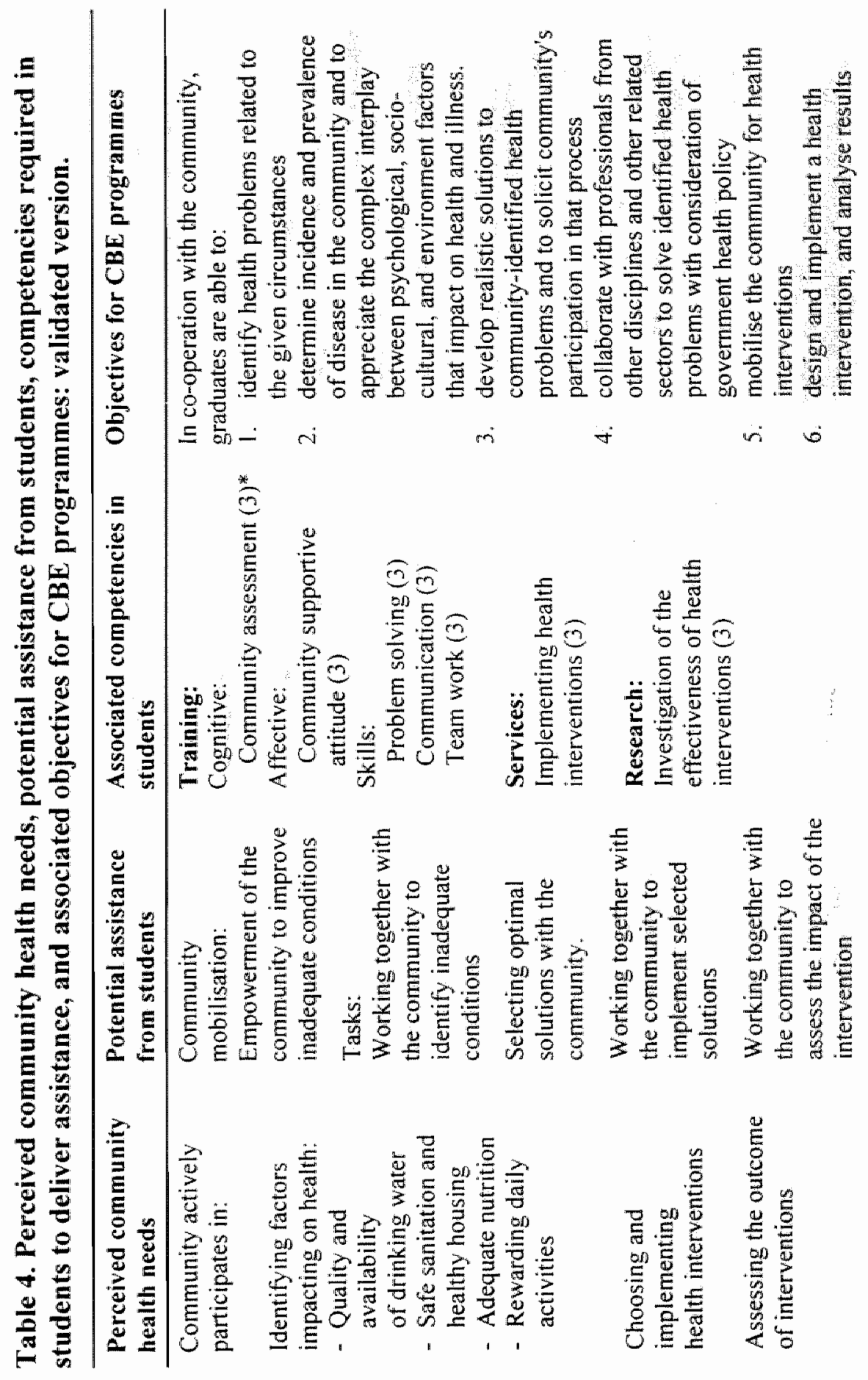




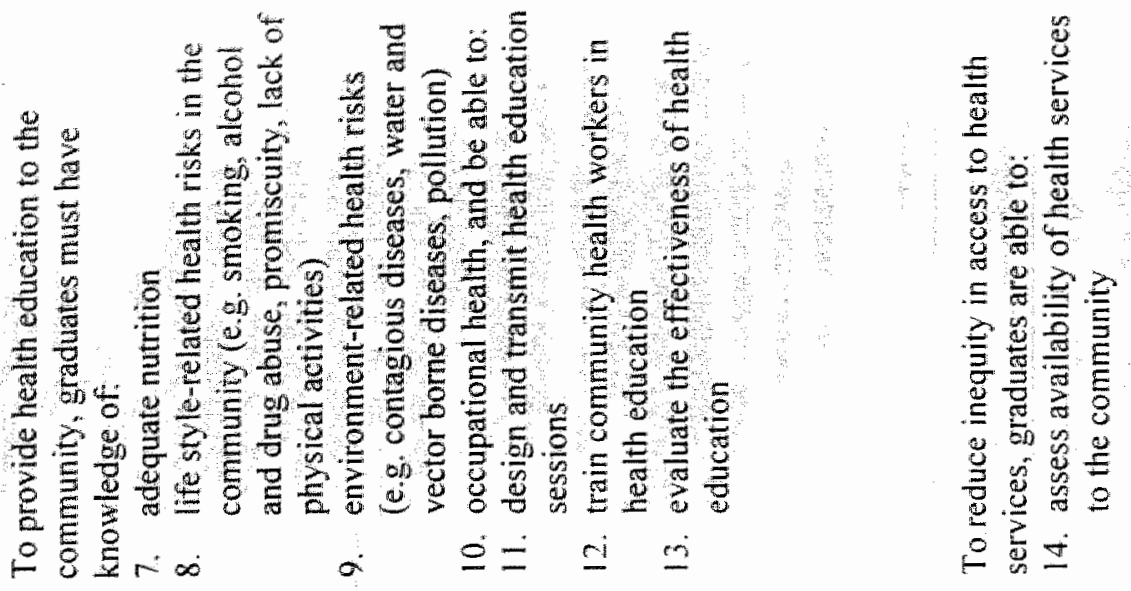

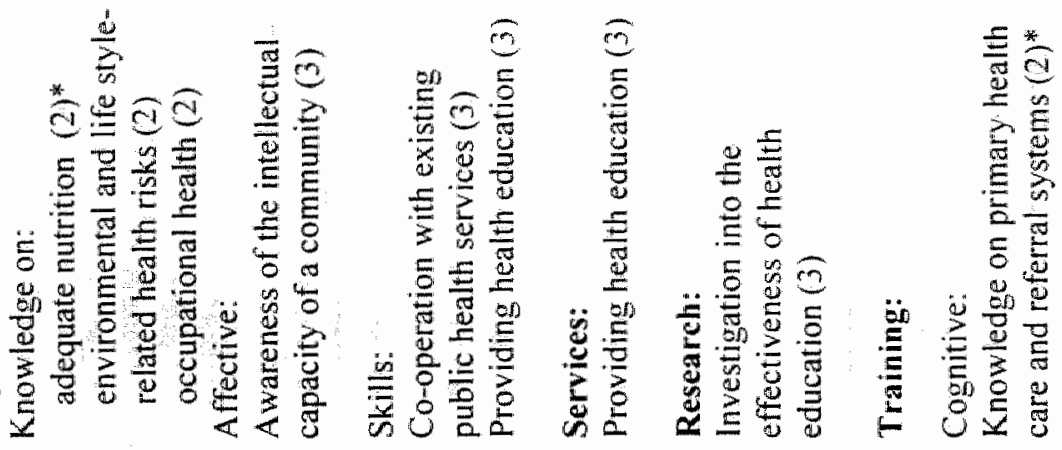

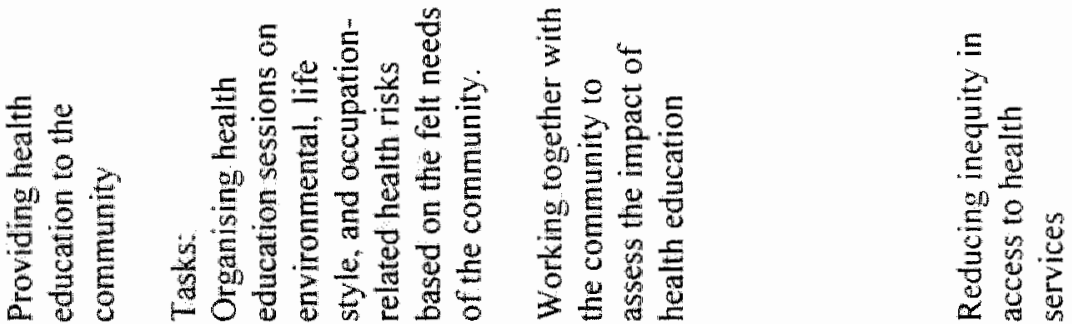
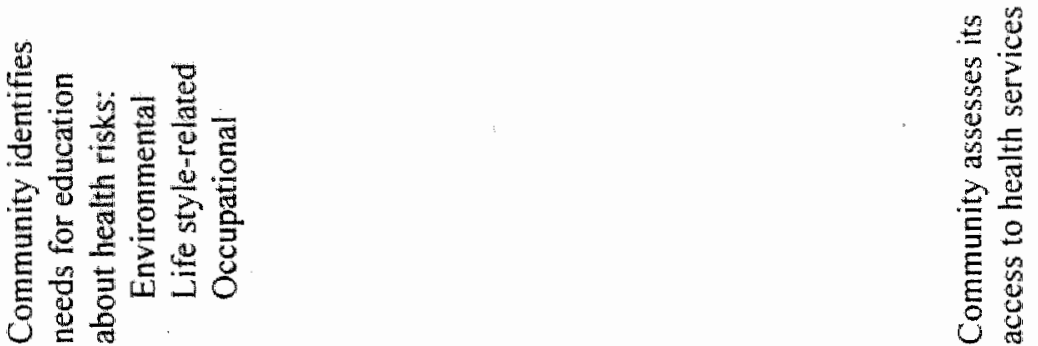
उ.

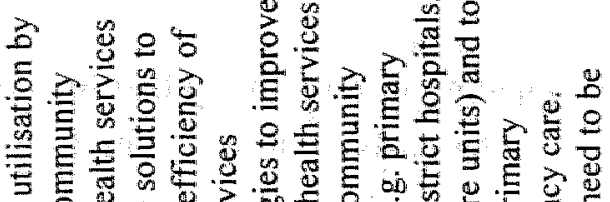

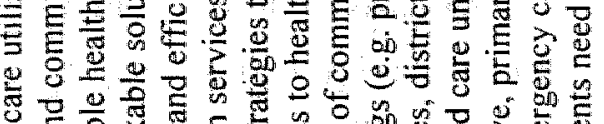

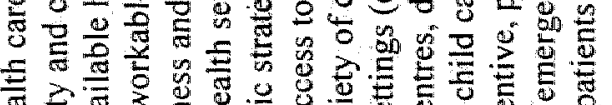

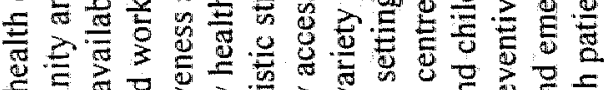

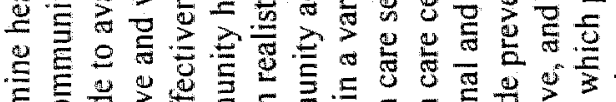

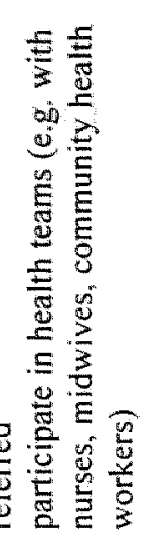

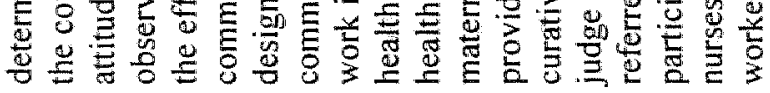

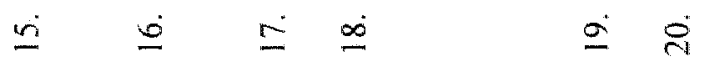
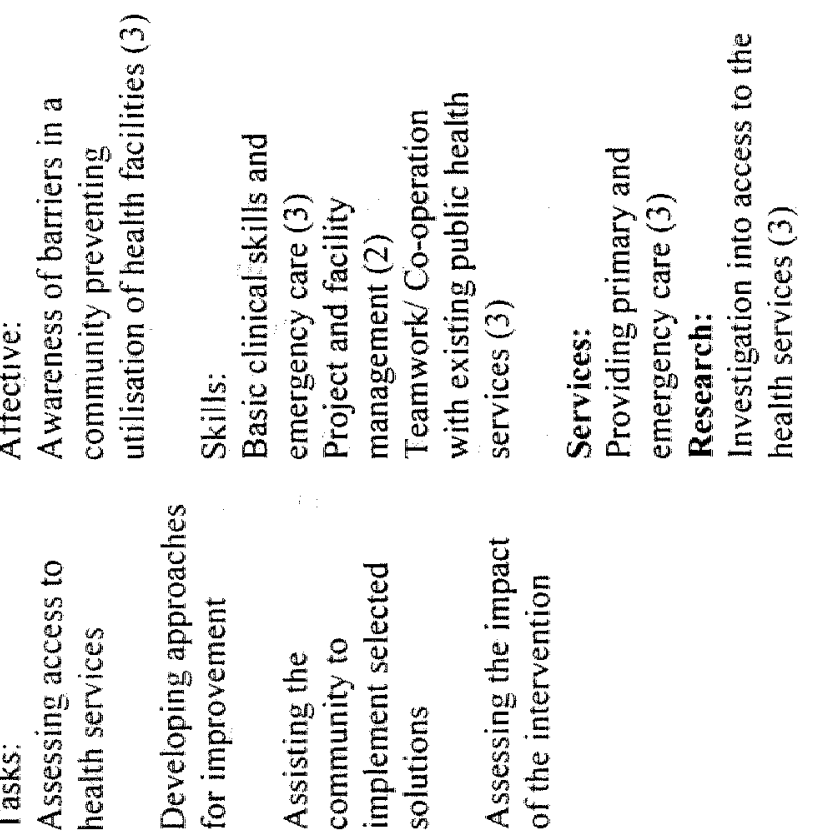

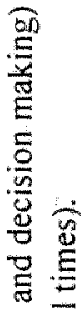

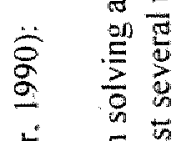

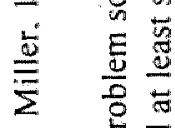

들

苟 2

造

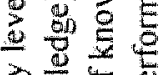

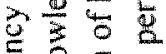

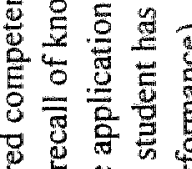

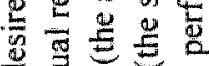

(2)

출

(1) $y$ m

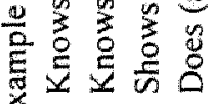

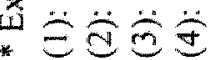




\section{DISCUSSION}

To ensure that medical schools participating in this survey had included CBE programmes in their curricula we purposively took a sample from Network: TUFH member schools residing in developing countries. For comparison, we also drew a comparable sample from non-Network: TUFH schools. Although only one-third of this non-Network: TUFH sample responded to the questionnaire, $83 \%$ of these schools had included CBE programmes in their medical curricula. This finding may confirm broad acceptation of CBE by medical schools in developing countries. ${ }^{21}$ However, a significant difference in the time devoted to CBE between Network: TUFH member and non-member schools was detected.

The low response rate among non-Network: TUFH schools may be explained by assuming that non-responder schools in this sample had not implemented CBE programmes and therefore felt not motivated to participate in this consultation. Opinions of responding non-Network: TUFH schools about our proposed generic CBE objectives were not statistically different from those of Network: TUFH schools, allowing us to pool data from both groups of respondents to assess the perceived relevance of our framework and the derived CBE objectives.

Apart from one 'neutral' score, 42 pooled respondents confirmed the relevance of our framework designed to derive generic CBE objectives. Four proposed objectives did not receive the pre-set $75 \%$ 'relevant' score. Based on quantitative and qualitative data, one of these objectives (pertaining to management of a primary care unit and sustaining health administration) had to be deleted from the proposed set of generic CBE objectives. In the past, individual schools (Suez Canal University, Egypt; University of Hawai, USA) had decided to address this objective in their CBE programmes.' Our decision to maintain the 
other three objectives was based on the fact that some respondents added positive comments about each of these objectives. For this decision there is further support in the literature. With respect to the objective: 'Graduates are able to monitor effectiveness and efficiency of community health services", Hamilton (2000) stated that both postgraduate and undergraduate health professions students need to understand each profession's contribution to patient safety and quality of care. ${ }^{22}$ In his view, students will only understand and learn how to respond to the inefficiency of community health services by being in the community and studying its health services. In relation to the objective: "Graduates are able to invent realistic strategies to improve community access to health services; Dowell et al. (2001) recommended to include opportunities for improving the health care of the communities as part of students ${ }^{\circ}$ task in undergraduate CBE programmes. ${ }^{5}$ With respect to the objective 'Graduates have knowledge on occupational health' the Eighth Joint ILO/WHO Report (1981) stated that special effort should be made to include occupational health and safety in basic medical courses. ${ }^{23}$ Furthermore, occupational health has been described as part of some CBE programmes for medical undergraduates. ${ }^{1.24}$

For the objective "Graduates are able to determine prevalence and incidence of diseases in the community the suggestion was made to add 'have knowledge on socio-cultural conditions related to health". Based on this suggestion and recent literature we expanded this objective to include and to appreciate the complex interplay between psychological, socio-cultural, and environmental factors that impact on health and illness. 25.20 .27

The quite low overall response rate to our questionnaire $(60 \%)$ limits the generalisability of the results from this study. Preferably, the validity of the framework and the derived generic $\mathrm{CBE}$ objectives should 
be enhanced by application in a variety of conditions. For example, we recently used the preliminary set of generic $C B E$ objectives as a reference to evaluate an existing $\mathrm{CBE}$ programme in a medical curriculum. $^{28.29}$ and to design a modified version of the same programme. $^{30}$

\section{ACKNOWLEDGEMENTS}

We are most grateful to the following medical schools for completing the questionnaire, which greatly assisted in the validation of our framework and the derived set of generic CBE objectives: Universidad Nacional del Sur, Argentina; Universidad de Buenos Aires, Argentina; Arabian Gulf University, Bahrain; University of Sciences \& Technology, Bangladesh; Universidade Estadual de Londrina, Brazil; University of Buea. Cameroon; Universidad de la Frontera. Chili; Universidad El Bosque, Colombia, Universidad Federada de Costa Rica; Suez Canal University, Egypt; Jimma University, Ethiopia; Christian Medical College, India; Gadjah Mada University, Indonesia; University of Sumatera Utara, Indonesia; Ben-Gurion University of the Negev, Israel; Technion Institute of Technology, Israel; University of the West Indies, Jamaica; University of Jordan; Moi University, Kenya; Universiti Sains Malaysia; Universiti Kebangsaan Malaysia; Universidad Autónoma Metropolitana, Mexico; Catholic University of Mozambique; University of Namibia; Kathmandu University, Nepal; Manipal College of Medical Sciences, Nepal: University of Maiduguri. Nigeria; Ziauddin Medical University, Pakistan; University of the Philippines; Cebu Institute of Medicine, Philippines; University of the Western Cape, South Africa; University of Stellenbosch. South Africa; King Fahd University, Saudi Arabia; University of Gezira, Sudan; International University of Africa, Khartoum, Sudan; Prince of Songkla University. Thailand; Khon Kaen University. Thailand; Makerere University, Uganda; Universidad Centro 
Occidental, Venezuela; Hanoi Medical University, Vietnam; Hue Medical College, Vietnam; University of Science and Technology, Yemen; and Aden University, Yemen.

\section{REFERENCES}

1. Feletti G, Ja'afar $R$, Joseph $A$, Magzoub $M$, McHarney-Brown C, Omonisi $K$, Refaat $A$, Wachs J, Sclrmidt HG. Implementation of Community-Based Curricula. In: Schmidt HG, Magzoub M, Feletti G, Nooman Z, Vluggen P. eds. Handbook of Community-Based Education: Theory and Practices. Maastricht: Network Publications. 2000;147-199.

2. Schmidt HG, Neufeld VR, Nooman ZM, Ogunbode T. Network of community-oriented educational institutions for the health sciences. Academic Medicine 1991:66:259-261.

3. Lennox A. Development and evaluation of a community-based, multi-agency course for medical students: descriptive survey. British Medical Journal 1998;316:596-599.

4. Seabrook MA, Lempp H, Woodfield SJ. Extending community involvement in the medical curriculum: Lessons from a case study. Medical Education 1999;33:838-845.

5. Dowell A, Crampton P, Parkin C. The first sunrise: An experience of cultural immersion and community health needs assessment by undergraduate medical students in New Zealand. Medical Edwcation 2001;35:242-249.

6. Omotara BA, Padonu MO. Yahya SJ. Assessment of the impact of community-based medical education of the University of Maiduguri on communities in three local government areas of Borno State, Nigeria: Community leaders' perspectives. Edwcation for Health 2004;17:6-16.

7. Kristina TN, Majoor GD, Van der Vleuten CPM. Defining generic objectives for community-based education in undergraduate medical programmes. Medical Education 2004:38:510-521.

8. Patton, M. Qualitative Evaluation and Research Methods. Newbury Park, CA: Sage Publications. 1990. 
9. World Bank. World Bank list of economies. Accessed July 2004. http:/www worldbank.org/data/databytopic/CLASSXLS.2004

10. Hamdy H, Mousawi $\mathrm{F}$, Ameen $\mathrm{S}_{\text {. Wahab }}$ A. Performances on the Bahrain licensure examination by graduates from two types of curricula. Academic Medicine 1991;66:629-630.

11. Margolis $\mathrm{CZ}$. Community-based medical education. Medical Teacher $2000 * 22: 482-484$

12. Richards R. 'Keeping our goal in mind'. Education for Health 2003; 16:2-3.

13. Kaufman A, Van Dalen J, Majoor G. Mora Carrasco F. The Network: Towards Unity For Health $-25^{\text {in }}$ anniversary. Medical Education 2004;38: $1212-1218$.

14. World Health Organization. World Directory of Medical Schools. Geneva: World Health Organization. 2000.

15. Schmidt HG, Magzoub M, Feletti G. Nooman Z, Vluggen P. Handbook of Communiry-Based Edwcation: Theory and Practices. Maastricht: Network Publications. 2000.

16. Bland JM. Statistical notes: Cronbach's alpha. British Medical Joumal 1997; $314: 572$.

17. Streiner DL, Norman GR. Health measwement scales. A pracrical guide to wheir development and use. New York: Oxford University Press. 2003.

18. Tigelaar DEH, Dolmans DHJM. Wolfhagen HAP, van der vleuten CPM. The development and validation of a framework for teaching competencies in higher education. Higher Education 2004:48:253-268.

19. Silverman D. Interpreting qualitative data. Methods for anabsing talk. text and interation. London: Sage Publications. 2001.

20. Oppenheim AN. Questiomaire Design and Aritude Measurement. London: Heinemann. 1966.

21. Morrison J, Watt G. New century, new challenges for community-based medical education. Medical Education 2003;37:2-3.

22. Hamilton JD. The quality of Australian health care study: Implications for education of failure in quality and safety of health care. Education for Health $2000: 13: 27-36$ 
23. Eight Report of the Joint ILO/WHO Committee on Occupational Health. Edwcation and training in occupation health, safery and ergonomios. Geneva: World Health Organization. 1981.

24. Musal B, Aksakoğlu G, Uçku R. Community-based education programme of Dokuz Eylül School of Medicine. Education for Health 2003:16:218-221.

25. Chin NP, Monroe A, Fiscella K. Social determinants of (un) healthy behaviours. Education for Health 2000;13:317-328.

26. Satterfield J, Mitteness L, Tervalon M. Adler N. Integrating the social and behavioural sciences in an undergraduate medical curriculum: The UCSF essential core. Academic Medicine 2004:79:6-15.

27. Shaw L, Mackinnon J. A multidimensional view of health. Education for Health 2004;17:213-222.

28. Kristina TN, Majoor GD, Van der Vleuten CPM. Does CBE come close to what it should be? A case study from the developing world evaluating a programme in action against objectives on paper. Education for Health 2005:18:194-208)

29. Kristina TN, Majoor GD, Van der Vleuten CPM. Does CBE come close to what it should be? A case study from the developing world. Students' opinions. Education for Health, submitted.

30. Kristina TN, Majoor GD, Van der Vleuten CPM. Comparison of a community-based education programme executed with and without active community involvement. Medical Education, accepted with revising. 


\title{
Chapter 4
}

\section{Does CBE come close to what it should be?}

A case study from the developing world.

Evaluating a programme in action against objectives on paper

\begin{abstract}
CONTEXT A growing number of health professions schools have implemented programmes for community-based education (CBE) for their students. There are indications, however, that particularly in developing countries, CBE programmes are not always optimally implemented or sustained.
\end{abstract}

OBJECTIVE To test the suitability of an established method for curriculum evaluation combined with a set of generic objectives for $\mathrm{CBE}$ programmes, for evaluation of CBE programmes.

METHODS As a case study, Coles and Grant's model for curriculum evaluation was applied to the CBE programme of the Medical Faculty of Diponegoro University (MFDU) in Semarang. Indonesia. Document analysis yielded information on the programme on paper; participatory observation and staff interviews on the programme in action. In addition, MFDU"s CBE programme was evaluated against a set of generic objectives for CBE programmes recently designed by us.

RESULTS MFDU has created great opportunities for its CBE programme in which, however, also significant weaknesses were revealed. (1) In the community, much time was spent on formal teaching; (2) Students' work in the community was not jointly identified with 
community members regarding the community"s felt health needs; (3) There was rarely continuity, and evaluation or follow-up of the students? work in the community; and (4) No systematic programme evalluations are carried out.

DISCUSION This evaluation study showed shortcomings in the implementation of MFDU's CBE programme. The major weaknesses identified point at an underutilization of the opportunities and potential jeopardization of the facilities in the community. On the other hand, more time is needed in the CBE programme to establish the health needs to be addressed jointlly with the community and to assess the impact of activities undertaken. A thorough review of the CBE programme, perhaps taking the outcomes of this study into account, could turn MFDU's CBE programme into a fine example for other medical schools in Indonesia and beyond.

CONCLUSION Coles and Grant's method for curriculum evaluation proved suitable for evaluation of a $C B E$ programme in a developing country. After additional comparison with a reference list of objectives for $\mathrm{CBE}$ programmes, reasoned suggestions for programme can be made.

\section{INTRODUCTION}

Community-based education (CBE) aims to train undergraduate medical students in the diagnosis, management and, if possible, solution of community health problems.' CBE activities should take place in a variety of primary and secondary health care settings and, particularly in developing countries, within communities. ${ }^{2.3 .4}$ The general objective of CBE programmes is to expand the students " notion of community health problems through their learning, service and research in the community and thereby to improve the health of the community in which the programme is carried out: ${ }^{5}$ Based on these aims, many medical schools, 
particularly in developing countries, have implemented CBE programmes. However, these programmes often suffer from negligence of and inappropriate approaches to, actual community involvement. ${ }^{6.7}$ Thus, some doubt exists whether CBE programmes are adequately implemented. So as a case study, we have evaluated the CBE programme executed by the Medical Faculty of Diponegoro University (MFDU) in Semarang, Indonesia, using the model of Coles and Grant (1985). According to this model, the "curriculum on paper". the "curriculum in action", and the "curriculum as experienced" by the students are evaluated.

The curriculum on paper includes what is written about the curriculum in documents, committee reports, etc., and what faculty says about the curriculum's aims and goals. The curriculum in action is how the intended curriculum is theoretically implemented in practice. The experienced curriculum is what students actually do, how they study, what they believe they should be doing, the learning that occurs and the outcome of their learning, which in line with "actualised curriculum." There can be considerable mismatches between these three curriculum concepts. ${ }^{10}$ In this report we compare MFDU's existing CBE programme with its description on paper and a set of generic objectives for $\mathrm{CBE}$ programmes recently developed by us. " We formulated the following research questions to evaluate the $\mathrm{CBE}$ programme at MFDU:

(1) What is the match between MFDU's CBE programme objectives and the generic list of CBE objectives?

(2) How are MFDU's CBE objectives implemented in the curriculum?

(3) Can any recommendations be formulated to improve MFDU's CBE programme? 


\section{CBE in MFDU's Curriculum}

MFDU has a six-year medical curriculum. The first two years emphasize basic sciences and years 3 and 4 clinical sciences. In those four years, lectures and practicals are the dominant educational formats. Some elements in this part of the curriculum may be relevant for the preparation of the students for their $\mathrm{CBE}$ programme, e.g. lectures on community medicine, epidemiology, occupational health, infectious diseases, and nutrition, as well as lectures and practicals on microbiology and parasitology. The last two years of the curriculum are predominantly devoted to clinical clerkships. CBE has two slots in the curriculum. In year 4 , students study family health problems in an urban area for two weeks. In year 6 , students participate in a 10 -week programme referred to as the CBE clerkship.

\section{METHODS}

The model of Coles and Grant to evaluate curricula was adopted for this study. The CBE programme in action was evalluated against its description on paper and against a set of generic objectives for CBE programmes. "This study exclusively used qualitative methods, because we aimed to gather detailed information on various aspects of the CBE programme, including its structure, faculty roles and student activities. Triangulation of methods was applied to increase the validity of our observations. ${ }^{12}$ To describe the curriculum on paper, written documents were analysed. ${ }^{13}$ Primary sources were the MFDU's study guide, which includes an outline of the CBE programme, and a report on the last meeting of the planning group for the CBE programme. ${ }^{b}$ Complementary 
information was provided orally by faculty involved in the execution of the CBE programme. To study the curriculum in action, the first author conducted participatory observations with 4 th year students during their home visits and with 6th year students in the full ten-week CBE clerkship programme.

To increase the reliability of the collected data, two cohorts of final year students (25 and 30 students) were observed. ${ }^{14}$ The observer passively participated in all activities of both cohorts and observed all student activities, and students and staff were aware of the purpose of the observer's presence. Observations were recorded in field notes, complemented with statements made by supervisors during activities and by heads of Primary Health Care (PHC) centres in informal interviews. The following steps were taken to analyse the records: linking student activities observed with related statements by supervisors; coding observations and statements as key points: organizing the key points into categories; and extracting themes with respect to execution of the $\mathrm{CBE}$ programme. ${ }^{15.16}$

To increase reliability of this data analysis, a volunteer (a psychologist acquainted with qualitative studies) was asked to code the field notes and staff comments pertaining to students" work in the community (weeks 4 and 5 of the CBE clerkship, see below). Coding by the first author was compared with coding by the volunteer and differences emerging were discussed to reach consensus.

\section{RESULTS}

\section{Programme on Paper}

The single objective of the CBE programme for 4 th year students states that the students should be able to manage health problems of 
urban families. The students are supposed to be supervised by faculty from six departments. A checklist was provided to monitor student activities. The objectives of the CBE clerkship in year 6 are listed in Table 1.

In week 1 of the CBE clerkship, students should be trained to deal with emergency cases through Advanced Trauma Life Support (ATLS). In weeks 2 and 3 students are assigned to study the management of a PHC centre. Students stay in a Rural Health Professions Training Centre (RHPTC) and visit one of three rural PHC centres. Students should participate in the centre's primary care programmes executed in the community. This training is supposed to be supervised by faculty from seven departments. In weeks 4 and 5, students stay in a different RHPTC to identify and solve health problems in a rural community. In weeks 6-8 students are posted in two municipality secondary hospitals. Students are expected to work in the hospital's emergency room, to provide health services in the outpatient department and to study the management of the secondary hospital, including the referral system. In week 9, students are posted in an urban district health office to study implementation of the national urban health programme. Week 10 is reserved for final examinations. All students should be submitted to oral examinations by lecturers of the department of Community Medicine. There are no written guidelines for these examinations. Furthermore, the description of the CBE programme does not refer to any format of programme evaluation.

Next, the objectives of MFDU's CBE programme were compared with the list of generic objectives for CBE (Table 1). All but two of MFDU's objectives for its CBE programme matched objectives presented in the generic list of CBE objectives. Conversely, 14 of the 21 generic objectives were not matched by MFDU's CBE objectives. 


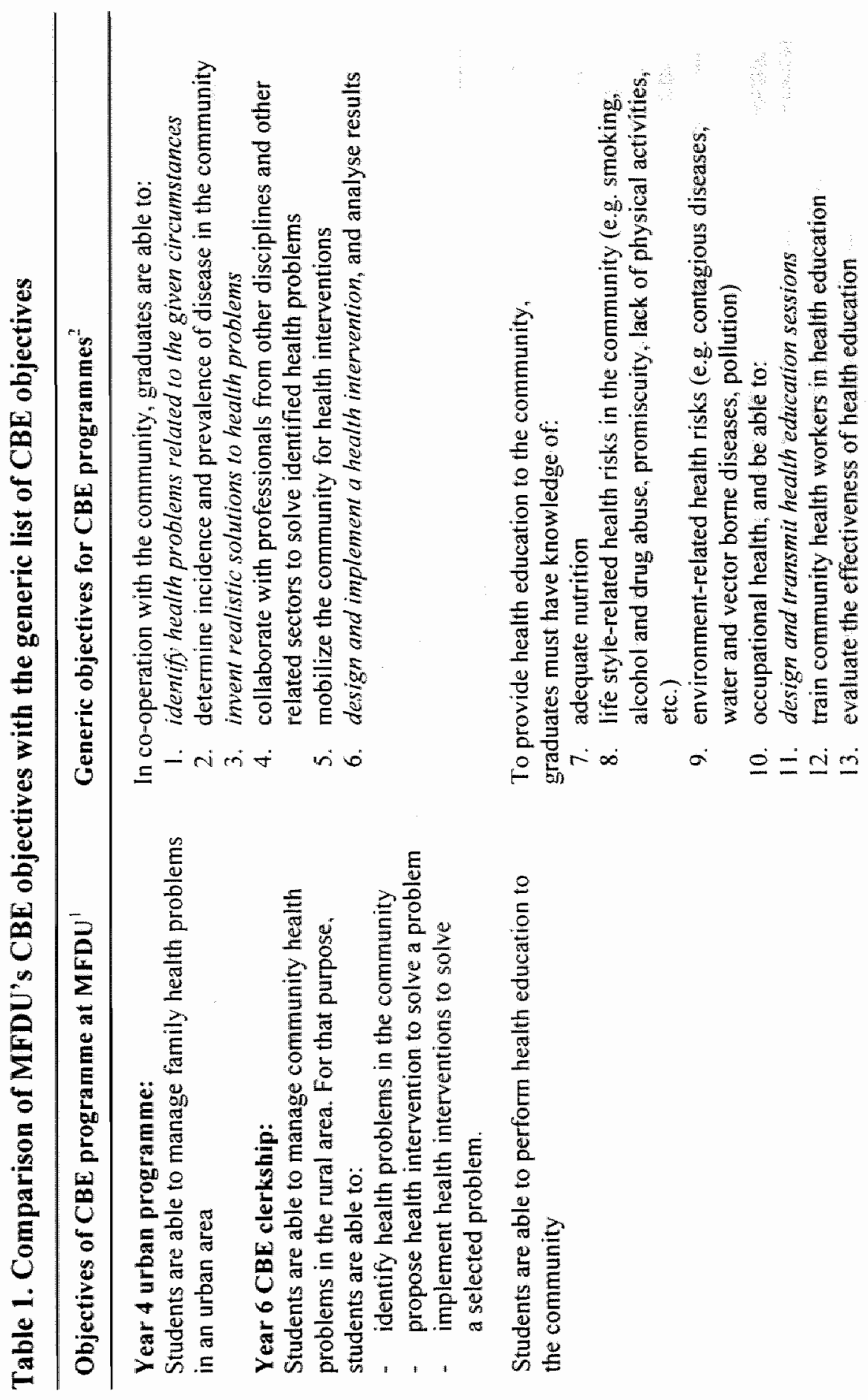




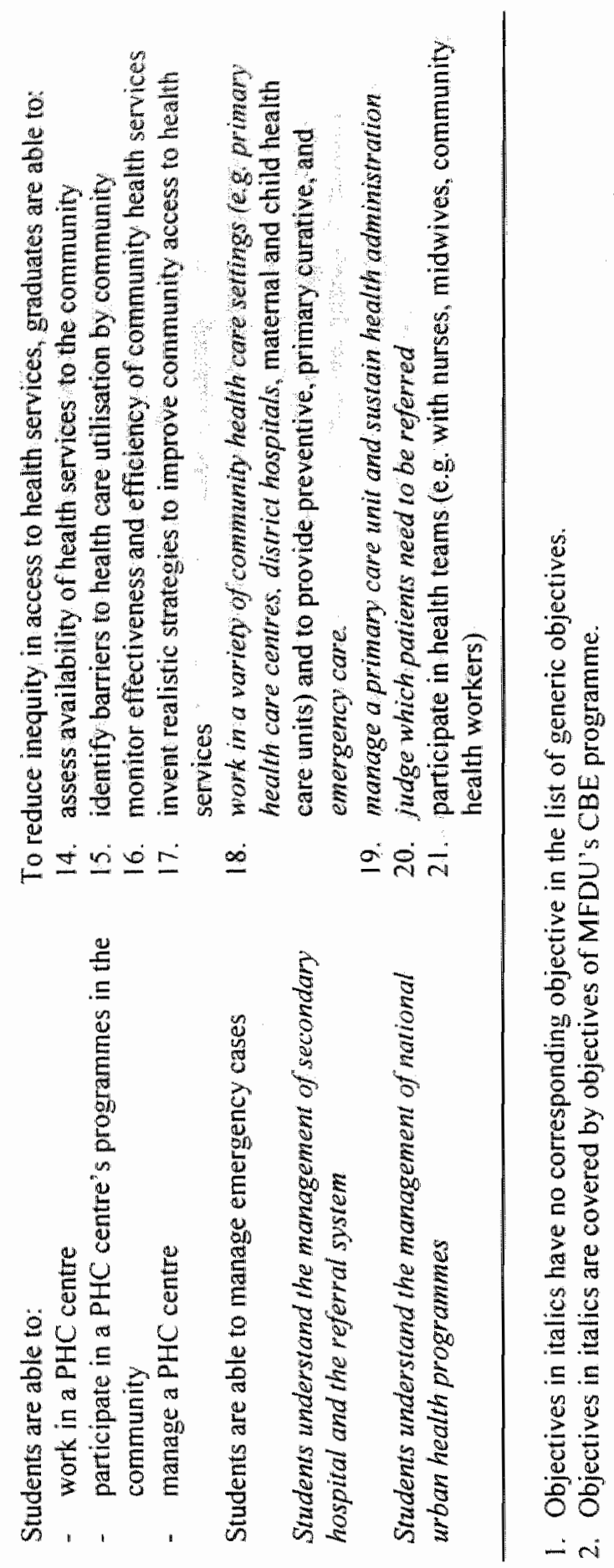




\section{Programme in Action}

Year 4 Programme. The first two days of this programme were used for lectures, discussions and introductions to community leaders and the head of an urban PHC centre. Students were divided in groups of 24-25 on the third day, and each group was sent from the PHC centre to one kampong (an urban unit like a block). Through home visits student groups were assigned to identify family health problems using a questionnaire, to analyse their data and write a report. Large variation in the time invested by the respective group supervisors was observed, and only one out of the four supervisors used the available checklist to monitor student activities. The last three days were used by the student groups to select a priority health problem and to discuss with community members how best to address that problem through a student-conducted health intervention. During these discussions with community members, not all students had a chance to talk. When the senior supervisor was asked what a student's mark for this programme would be based on, he replied:

"A student's score is based on his/her group's activities and report. A student will obtain a high score if he/she proposed a good and new idea to solve a specific health problem or was very active during discussions."

\section{Year 6 CBE Clerkship}

Week 1: ATLS. As a preparation for posting in the Municipality secondary hospital (week 6-8), ATLS took place in MFDU's skills training facility where students attended lectures and trainings conducted by clinicians from various disciplines. In line with the roster for this week, the ratio of time spent on lectures and practicals was 2:1. Assessment was based on four objective structured clinical examination (OSCE) stations conducted on the last day of this week. 
Weeks 2 and 3: Management of a PHC Centre. In the RHPTC, students were lectured for a total of 32 hours on the management of a PHC centre and related topics. In the first week, students in subgroups of 8-10 were given last year's patients' data of a PHC centre and asked to identify the priority health problems to be tackled by that PHC centre. In the second week, students participated for two days in PHC field programmes. They cooperated with midwives and community health workers to provide simple care and public health-related activities. Students' discussions with the supervisor from the RHPTC were conducted in the evenings, when students received advice on writing their reports. Deviating from the clerkship programme on paper, students" activities were not supervised by MFDU faculty. MFDU staff only came to the RHPTC to participate in the final examination of the students. Students had to give oral presentations on applying their approaches to community health problems identified from the PHC centre's data. Student presentations were assessed by their supervisor, three heads of the PHC centres, and MFDU faculty. When a staff member of Community Medicine was asked whether he felt this training met MFDU's CBE objectives, he replied:

"The objective of this training is that the students should acquire the ability to manage a PHC centre. Therefore, students should work in a PHC centre and in the community to collect data. Instead students receive last year's data as assembled by a PHC centre."

Thus, the management of a PHC centre was mainly addressed in lectures at the RHPTC. Students did not work in a PHC centre as described in the outline for the CBE clerkship, and when participating in a PHC programme, students just assisted in the daily work of community health workers and health providers. 
Weeks 4 and 5: PHC-related Activities in the Community. Two MFDU staff stayed with the students at another RHPTC and supervised their training. Student cohorts were divided in two groups of 12-15, and each group was sent to a PHC centre. Small groups of 3-5 students were formed and assigned to a health provider responsible for execution of a governmental PHC programme. Within the programme, students had to identify a specific problem, propose solutions for that problem, and implement one of the proposed solutions. With only one exception, none of the students' programmes included an evaluation of the impact of their interventions. Student assessment was based on written reports, oral presentations and the supervisors" records of student's attitude in daily activities on the parameters responsibility, discipline and teamwork. After the oral presentations, a head of a PHC centre commented:

"I noticed that the community already gets annoyed with the students" activities. I think if the student's activities were based on the community's felt needs they would be more useful. However, we are assigned to execute the programmes of the government as soon as possible, and by working together with the students these programmes can be finished on time."

When asked about the continuity of the students" activities, a supervisor answered:

"Due to their perceived urgency, the PHC centres must execute all government health programmes immediately, so hardly any of the students" programmes can be continued, because a next group of students has to work in a new programme. However, there are a few examples of continuity in students" programmes and records of their success." 
Thus, although formally assigned to identify health problems in the community, students had no chance to explore the community's felt needs but had to assist in the execution of government programmes. Usually there was no continuity in the students' programmes, and the outcomes were not assessed.

Weeks 6-8: Municipality Hospital Service and Management. For their postings in municipality secondary hospitals, students were divided into two groups of 12-15 students, and each group was sent to a different hospital. Under supervision, students provided curative care in the emergency room, in the outpatient clinic and conducted one or two normal deliveries. Assessment was based on selected emergency case presentations, In one hospital, subgroups of 3-4 students were assigned to write a report on the management and referral system of a selected hospital unit, e.g. the children's ward. The students collected data from documents, observations and interviews with nurses, doctors and the hospital director. Assessment was based on students ' reports and oral presentations in front of the hospital's vice-director, staff and their supervisor. The objective to study the management of a secondary hospital and the referral system was not addressed in one municipality hospital. There was no MFDU supervisor there, and when the vicedirector of this hospital was asked why this topic was ignored, he stated he was not aware of this objective in relation to the posting.

Week 9: District Health Service in an Urban Area. During the first three days of this week, students were lectured on urban district health programmes and management of a district health office. Students participated in health programmes for the last two days. There was no assessment or evaluation to conclude this week. 
Week 10: Final examination. The clerkship's final oral exams took place in MFDU's department of Community Medicine. A lecturer commented about this examination:

"We already received the students" marks on their training in PHC centres, in the community, and in the municipality secondary hospitals. If they passed those parts, at this examination they can only boost their score. However, we still have students who fail this exam, and she or he should redo the training or follow a remedial teaching programme."

\section{Comparison of the Programme on Paper and in Action}

We labelled aspects of the implemented CBE programme that contributed to the realisation of MFDU's objectives as strengths and aspects that may not be supportive in that regard as weaknesses (Table 2). Based on the latter and on the comparison of the objectives of the CBE programme at MFDU with the generic set of CBE objectives (Table 1), the following important weaknesses of MFDU"s CBE programme were identified:

(1) Much time is spent in community sites on instruction (e.g. lectures) that also could have been given at MFDU.

(2) Students' work in the community is not based on joint identification with community members of the community"s felt health needs.

(3) There is rarely continuity evaluation or follow-up of the students' work in the community.

(4) No systematic programme evaluations are carried out. 


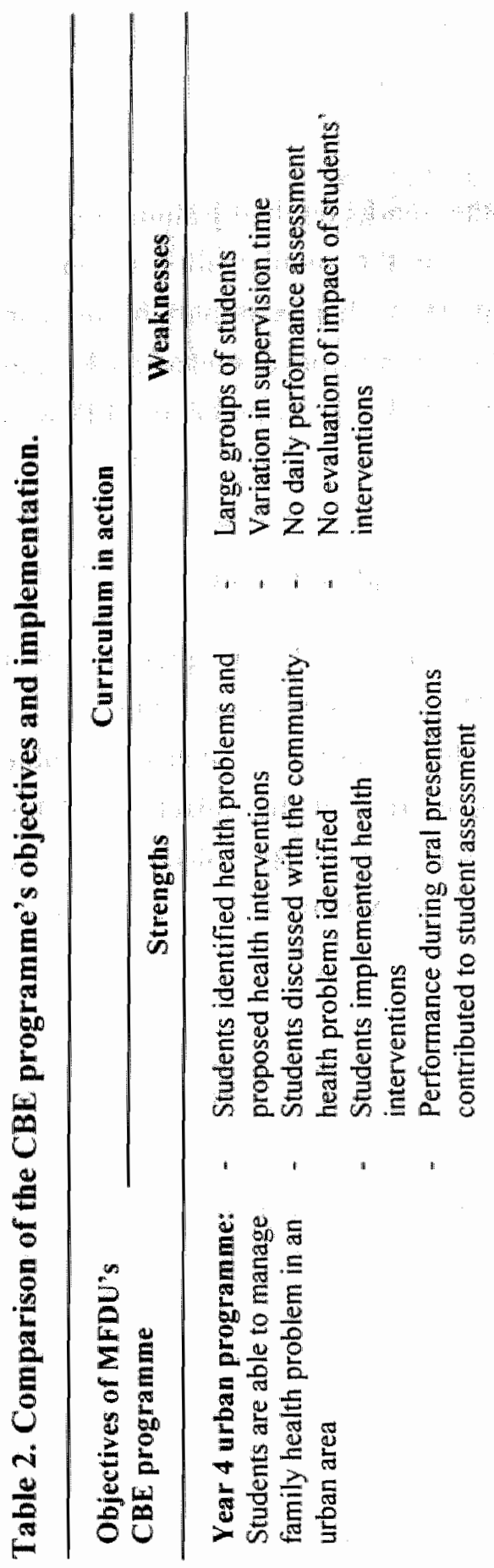

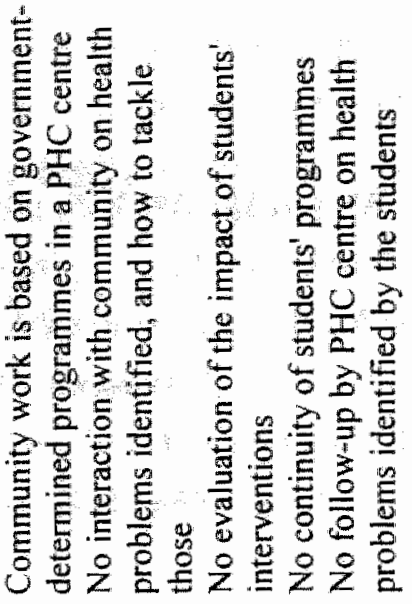

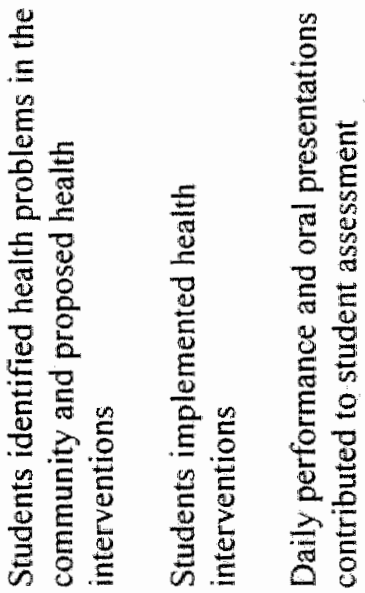

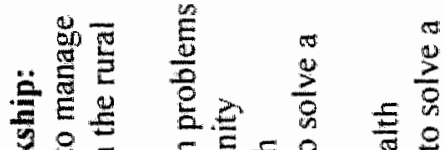
혼욜

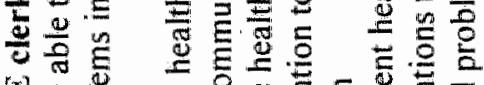

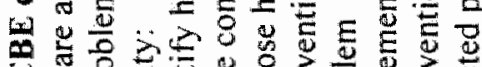

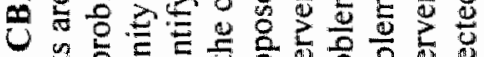

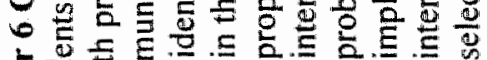
焉焉垔 

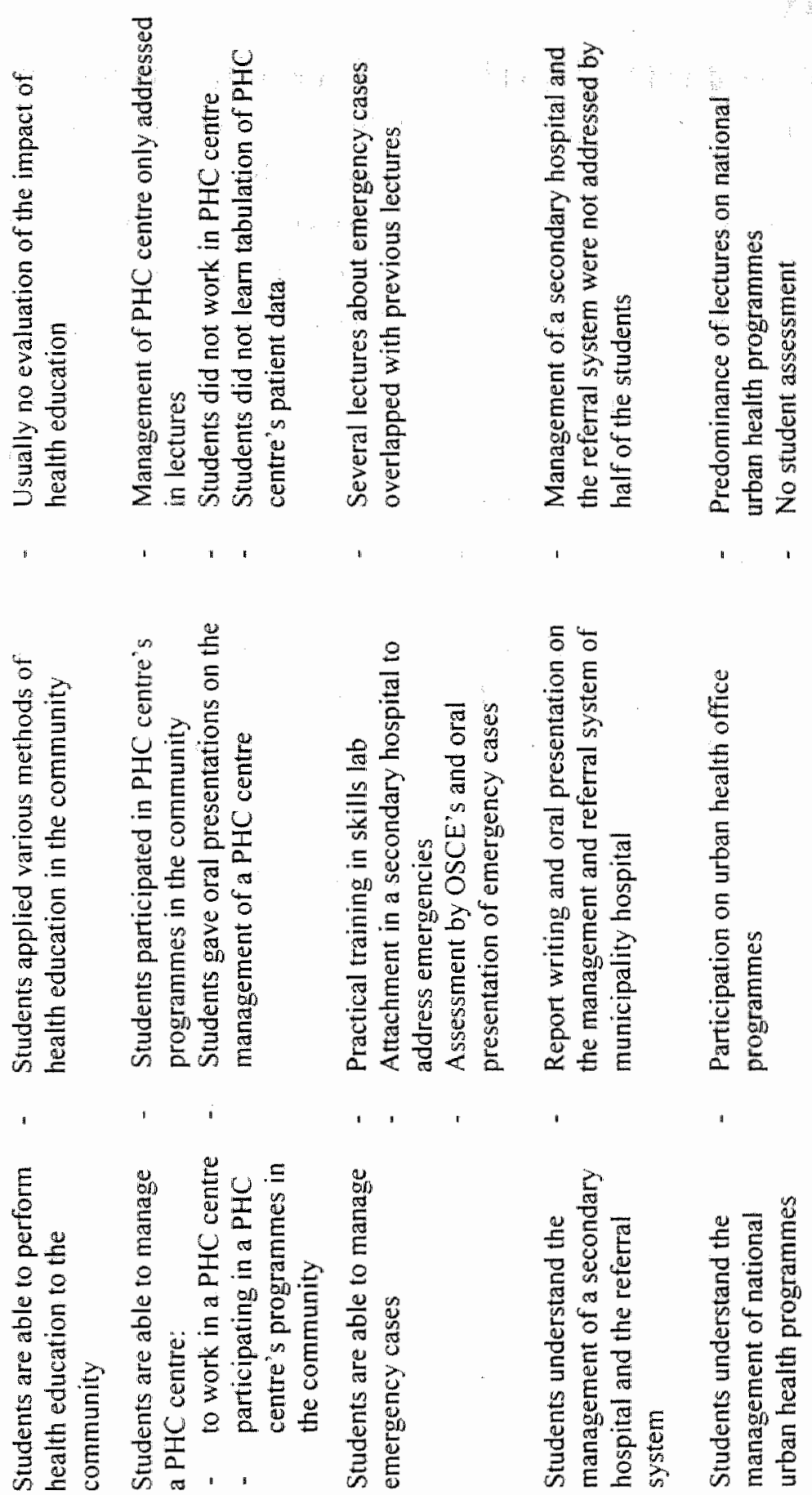


\section{DISCUSSION}

We applied the model of Coles and Grant to a case study evaluating the CBE programme of MFDU. Assessment of this programme in action in relation to its objectives and a set of generic objectives for $\mathrm{CBE}$ programmes, " revealed some important discrepancies. In accord with the model of Coles and Grant, we have also gathered data on the students' perception of the CBE programme, which will be presented separately.

Two objectives of MFDU's CBE programme, addressing the management of a secondary hospital and the national urban health programme, had no counterpart in the generic list of objectives. We feel the management of a secondary hospital does not fit a CBE programme, and we suggest addressing this objective elsewhere in the curriculum. The Indonesian national urban health programme focuses on environment and occupational health. Thus, students working on this programme may address objectives 9 and 10 in the list of generic objectives (see Table 1).

About two-thirds of the objectives in the generic list were not recognized in the objectives for MFDU's CBE programme. Some of the objectives specified in the generic list may, however, be addressed by the programme in action, even if there is no specific objective in MFDU's programme outline. For example in week 3 of the CBE clerkship, students co-operated with midwives and community health workers. This activity could be interpreted to match generic objective 21 referring to participation in health teams. In a case like this, MFDU would be advised to adopt a similar objective for its CBE programme, which would secure future inclusion of the corresponding activity in the CBE programme. Other objectives from the generic list may be addressed in the non-CBE curriculum of MFDU. Some lectures and practicals in years 2-4 are likely to be relevant to prepare the students for their CBE programme. 
However, the current objectives of the CBE programme do not certify that these topics are revisited and applied when the students are posted in the community.

The major weaknesses identified in MFDU's CBE programme point at an underutilization of opportunities and potential jeopardization of the facilities in the community. On paper, 12 weeks in MFDU's curriculum are earmarked for CBE, but in practice only about half of that time is used for learning in the community. The rest is taken for lectures and activities in facilities remote from the community. On the other hand, more time is needed in the CBE programme to jointly establish the health needs to be addressed with the community and to assess the impact of activities undertaken. ${ }^{17.18}$ The current failure to involve the community in directing the students' activities and the lack of continuity and follow-up. may erode the community's interest in receiving MFDU students. ${ }^{7}$

Finally, we did not find any internal evaluation of MFDU's CBE programme. In line with this, we noted that the CBE planning group had not convened since 1991. We recommend that MFDU introduce programme evaluation for (the respective parts of) its CBE programme and annually discuss these evaluations in the planning group and education committee. ${ }^{19} \mathrm{CBE}$ yields great opportunities for medical students to get acquainted with common health problems at the community level and to enter into cooperation with the community and their health providers to address these problems. In developed countries, CBE will often focus on primary health care as offered by general practices and family practitioners. ${ }^{211}$ In developing countries, the emphasis is usually more on cooperation with community members to jointly tackle their priority health problems..$^{21.22}$ We are impressed by the conditions created by MFDU and its partners for CBE. A thorough review of the CBE programme, perhaps taking the outcomes of this study into account, could turn MFDU's CBE programme into a fine example for other medical schools in Indonesia and beyond. 


\section{CONCLUSION}

Coles and Grant's method for curriculum evaluation proved suitable for evaluation of a $\mathrm{CBE}$ programme in a developing country. After additional comparison with our reference list of objectives for $C B E$ programmes (Kristina et al., 2004), ${ }^{11}$ reasoned suggestions for improvement of the programme could be derived.

\section{ACKNOWLEDGMENTS}

This study was undertaken in the framework of the Quality Undergraduate Education Project of the Faculty of Medicine, Diponegoro University, Semarang, Indonesia, which is funded by the World Bank. We are grateful to MFDU's CBE clerkship supervisors, Nurkukuh, MD and Bambang Hariyana, MD, for supplying information on the CBE programme on paper. We also thank Hastaning Sakti, MSc for controlling coding of records on weeks 4 and 5 of the CBE clerkship.

\section{REFERENCES}

1. Feletti G, Ja'afar R, Joseph A, Magzoub M, McHarney-Brown C, Omonisi $K$, Refaat A, Wachs J. Schmidt HG. Implementation of Community-Based Curricula. In: Schmidt HG, Magzoub M, Feletti G. Nooman $Z$, Vluggen P. eds. Hondbook of Community-Based Education: Theory and Practices. Maastricht: Network Publications. 2000;147-199.

2. WHO study group report. Commnnity-based Education of Health Personnel. Geneva: World Health Organization. 1987.

3. Nooman Z.M. Implementation of a community-oriented curriculum: The task and the problems. New direction for medical education. In; Lipkin M, ed. Problem-Based Leaming and Community-Oriented Medical Education. New York: Springer Verlag. 1989. 
4. Hamad B. Community-oriented medical education: what is it? Medica Educarion 1991;25:16-22.

5. Magzoub ME, Schmidt HG. A taxonomy of community based medical education. Academic Medicine 2000;75:699-707.

6. Ezzat E. Role of the community in contemporary health professions education. Medical Education 1995;29(suppl.1): 44-52.

7. Williams RL, Reid SJ, Myeni C, Pitt L, Solarsh G. Practical skills and valued community outcomes: The next step in community-based education. Medical Education 1999;33:730 737 .

8. Coles CR, Grant JG. Curriculum evaluation in medical and health care education. Medical Education 1985;19:405-422.

9. Nelson $\mathrm{M}$, Jacobs $\mathrm{C}$, Cuban L. Concepts of curricullum. Teaching and Learning in Medicine 1992;4:202-205.

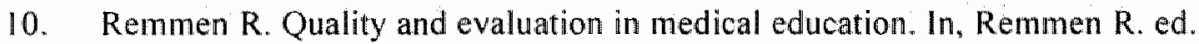
An Evaluation of Clinical Skills Training at the Medical School of the University of Annwerp. Antwerpen: thesis. 1999.

11. Kristina TN, Majoor GD, Van der Vleuten CPM. Defining generic objectives for community-based education in undergraduate medical programmes. Medical Edrcation 2004;38:510-521.

12. Harris [B. Qualitative methods. In Norman GR. Van der Vleuten CPM, Newble DI, eds. International Handboak of Researth in Medical Education. Dordrecht: Kluwer Publications. 2002.

13. Patton MQ. Qualitative Evaluation and Rasearch Methods. Newbury Park. C.A: Sage Publications. 1990.

14. Adler PA, Adler P. Observational techniques. In. Denzin NK, Lincoln YS. eds. Handbook of Qualitative Research. Thousand Oaks, CA: Sage Publications. 1994.

15. Dignan MB. Measurement and Evaluation of Healh Education. Springfield. IL: Charles C Thomas Publishers. 1989.

16. Miles MB, Huberman A. An Expanded Soumcebook Qualitative Data Analysis. Thousand Oaks, CA: Sage Publications. 1994.

17. Mishriky AM. Practicability of the results of elective studies in the community. Annals of Community-Oriented Education 1994:7:183-190. 
18. Wolf $M$, Maurana $C A$. Building effective community-academic partnerships to improve health: A qualitative study of perspectives from communities. Academic Medicine 2001:76:166-172.

19. Rotem A. Evaluation to improve educational programmes. Annals of Community-Oriented Education 1992;5:135-141.

20. Boaden N, Bligh J. Community-based medical education. Towards a shared agenda for learning. London: Arnold. 1999.

21. Khan MZ, Baillie $P$. An integrated approach through health, education and community development for the developing countries: The Baqai Model. Education for Health 2003;16:75-78.

22. Omotara BA, Padonu MKO, Yahya SJ. Assessment of the impact of community-based medical education of the University of Maiduguri on communities in three local government areas of Bomo State. Nigeria: Community leaders' perspectives. Education for Healh;2004;17:6-16. 


\section{Chapter 5}

\section{Does CBE come close to what it should be?}

A case study from the developing world.

\section{Students' opinions}

\section{Abstract}

CONTEXT There has been an increase in the number of medical schools implementing community-based educational (CBE) programmes. However, there are doubts whether CBE programmes are appropriately implemented. As a case study we evaluated the 12-week CBE programme of the Medical Faculty of Diponegoro University (MFDU) in Semarang, Indonesia. Earlier, we compared MFDU's CBE programme on paper and in action and evaluated the programme against a reference set of objectives for CBE programmes recently developed by us. Evaluation of this CBE programme should be complemented with an account of the students` perceptions.

OBJECTIVE To acquire MFDU's students opinions on their CBE programme as part of a comprehensive evaluation of an existing CBE programme.

METHODS Coles and Grant's model for curriculum evaluation was applied. To assess the curriculum as experienced by the students, direct participatory observation was performed and focus group discussions conducted to collect students" opinions.

RESULTS Most student comments confirmed the conclusions drawn after comparison of MFDU's CBE programme on paper and in action. No contradictory student comments were recorded. Students specifically 
signalled: 1) frequent overlap of lectures given during the CBE clerkship and previously in the regular programme, 2) mismatch between their activities in the community and the community's felt health needs, 3) greater benefits of the CBE programme for PHC centres and students than for target communities, and 4) incidental defective co-operation between students and health providers or community health workers.

CONLUSION As part of Coles and Grant's approach to curriculum evaluation, also students" comments were collected. These comments yielded more in-depth information on the CBE programme evaluated and facilitated formulation of recommendations for improvement of that $\mathrm{CBE}$ programme.

\section{INTRODUCTION}

Community-based education (CBE) has been implemented by a growing number of medical schools, particularly in their undergraduate medical programmes. CBE is an educational format advocated to teach students management of priority health problems within the community.' Many studies reported valuable learning experiences for students attending $C B E$ programmes in community-based health facilities. ${ }^{2.3 .4}$ However, there are doubts whether CBE programmes are appropriately implemented. Shortage of resources and negative perception of CBE by faculty particularly in developing countries are reasons why CBE programmes are not always successfully implemented. ${ }^{5.6}$ In addition, students may not fully appreciate the value of community experiences. and community participation may not develop satisfactorily. ${ }^{8}$

As a case study, we evaluated the CBE programme of the Medical Faculty of Diponegoro University (MFDU) in Semarang, Indonesia, using the model of Coles \& Grant (1985) as a method of curriculum 
evaluation. ${ }^{9}$ According to this model, subsequently the curriculum on paper, the curriculum in action, and the curriculum as experienced by the students are evaluated. The 'curriculum on paper' includes what is written about the curriculum in documents, committee reports, etc., and what faculty says about the curriculum's aims and goals. The curriculum in action" is how the intended curriculum is theoretically implemented in practice. The "experienced curriculum is what students actually do, how they study, what they believe they should be doing, the learning that occurs, and the outcome of their learning, which in line with actualised curriculum: "There can be considerable mismatches between the three concepts of the curriculum as distinguished above. "In a recent paper we evaluated MFDU's CBE programme in action against the programme on paper and we compared the objectives of MFDU's CBE programme with a set of recently developed generic objectives for CBE programmes. ${ }^{12}$ Based on both comparisons four important weaknesses of MFDU's CBE programmes were revealed. ${ }^{13}$ 1) In the community much time is spent on formal teaching; 2) Students" work in the community is not based on the community"s felt health needs jointly identified by community members and students; 3) There is rarely continuity in, and evaluation or follow-up of the students work in the community; and 4) No systematic programme evaluations are carried out.

To complete the evaluation of MFDU's CBE programme also its perception by the students should be explored (the experienced curriculum; Coles \& Grant, 1985). We here report the opinions of MFDU students on their CBE programme and compare their comments with our observations on the CBE curriculum in action. In particular we focused on student comments deviating from, or providing complementary information on the conclusions quoted above. In the discussion we will complete the evaluation of MFDU's CBE programme and present suggestions for improvement. 


\section{CBE in MFDU's curriculum}

MFDU has a six-year medical curriculum. The first two years emphasise basic sciences and years 3 and 4 clinical sciences. The last two years of the curriculum are predominantly devoted to clinical clerkships. The CBE programme has two slots in the curriculum. In year 4 , students for two weeks study family health problems in an urban area and pay home visits. In year 6 , students participate in a 10 -week programme referred to as the CBE clerkship. Further details on the structure of MFDU's CBE programme are given elsewhere. ${ }^{13}$

\section{METHODS}

Students " opinions on MFDU's CBE programme were collected using the qualitative methods of participatory observation and focus group discussion (FGD). The first author conducted participatory observations with one cohort of 25 students in their two-week CBE programme in year 4 , and with two cohorts of 25 and 30 students, respectively, in their ten-week CBE clerkship in year 6. Students' comments and answers to explorative questions asked by the observer during their $\mathrm{CBE}$ activities were recorded. The following steps were taken to analyse these records: 1) linking students' activities and related comments and answers to questions, 2) coding comments and answers as key points, 3) organising the key points into categories, and 4) extracting themes with respect to the practical implementation of the programmes. ${ }^{14}$ To increase the reliability of this analysis, a volunteer (a psychologist acquainted with qualitative studies) was asked to also code the comments and answers pertaining to weeks 4 and 5 of the CBE clerkship, when the students worked in the community. Coding by the first author was compared with coding by the volunteer and differences emerging were discussed to reach consensus. 
To further explore the students' perception of the CBE programme, FGD's were planned for 45 students randomily picked from the total population of 143 final year students who had completed their CBE clerkship. Focus groups of 15 students met for 90 minutes during lunchtime. Students' transportation expenses were reimbursed and they were provided free lunch. FGD's were moderated by one of the authors (TNK). Since she is not a CBE clerkship supervisor students were assumed to feel free to express their opinions. The moderator explained that the outcomes of the FGD would be used to improve MFDU's CBE programme; she set the rules for the FGD and promised anonymous and confidential handling of their comments. ${ }^{15}$ During these FGD's open questions were used. At the end of each FGD students were encouraged to suggest improvements in the CBE programme. FGD's were taperecorded and later transcribed verbatim. Answers to similar questions asked in each of the FGD's were clustered and coded by the first author. Analysis across the FGDs involved detecting patterns or trends, identifying themes expressed by focus group participants, and attaching meaning (interpretation) to this results. ${ }^{16}$ The same volunteer who verified comments and answers was asked to independently identify themes in the transcript of focus group discussions. Codings by the first author (TNK) and the volunteer were compared and discrepancies discussed to reach consensus.

\section{RESULTS}

Student opinions were extracted from field notes made during participating observation and transcripts of FGD"s. Forty-one out of 45 selected students attended three FGD's; the four students not showing up apologised due to obligations in the hospital. Gender distribution of the students was $70.7 \%$ female and $29.3 \%$ male. This gender distribution is similar to the gender distribution in the year class $(67 \%$ female; $33 \%$ 
male). FOD's were held on three consecutive days; 14 students participated in the first and third group, and 13 in the second. Many of the students" comments made during the CBE programme and in FGD"s confirmed our conclusions drawn after comparison of MFDU's CBE programme on paper and in action (see Introduction) and therefore will not be presented. No student comment was recorded that contradicted our earlier conclusions on the curriculum in action. Below we will exclusively focus on student comments that expanded our insight in the CBE programme in action.

With respect to the CBE programme in year 4 , most negative comments pertained to the large groups of 25 students that were sent into urban blocks ('kampongs') to pay home visits. Although each student individually visited about 15 households, all data had to be compiled and presented in one report. This caused large variation in the contributions by individual students. Other negative comments related to the many groups of students that had previously visited the same kampong and presumed subjectivity of supervisors in student assessment. Pertaining to this assessment one student stated:

"I don't know how the supervisor could give me my mark because he seldom observed our activities. Students who were very active during discussions received high marks, even if they had been very lazy in data analysis and report writing".

With respect to the CBE programme we had already observed much time in the CBE programme to be spent on instruction, particularly by lectures. Students" comments confirmed this observation and added that the content of those lectures often overlapped with lectures already given in the regular programme. Remaining comments could be clustered in three categories: benefits to the community; co-operation with other health professionals; and suggestions to improve the CBE programme. 


\section{Benefits to the community}

With respect to their work in the community during weeks 4 and 5 of the CBE clerkship, also the students - like we before - had observed that the PHC centres were instructed by the District Health Office on the community health programmes to be executed. Some students even felt abused by the PHC centre in the execution of these community health programmes. One of them said:

"At least we should work together with the health providers to collect data, but they did not help us, even though this was a large target area with many households to be visited, and the available time was limited".

Students confirmed our conclusion that these community health programmes often did not respond to the felt health needs of the community. Consequently, the students estimated the benefits of some community health programmes to be greater for the PHC centre and themselves than for the community involved. A pertinent student statement:

"We only used the community as a learning resource. For instance, we took sputum from individuals suspected of tuberculosis. We should inform them whether the test was positive or negative. However, we did not do that due to lack of time".

\section{Co-operation with other health professionals}

Co-operation between students and health providers and community health workers did not always develop satisfactorily. For instance when presenting data on poverty and immunisation coverage, the students collected and presented data contradicting those routinely 
used by the midwives. Consequently, the students felt the midwives were reluctant to receive and co-operate with the students. Two students who worked together with a community health worker felt this community health worker to be annoyed with their activities. One of them related:

"The community health worker told our group that every time the students came to the village, she and her colleagues would receive additional instructions. However, they never received anything in return from the students or the PHC centre".

\section{Students'suggestions to improve the CBE programme}

At the end of the FGD's students were encouraged to raise suggestions for improvement of the CBE programme. The following suggestions were made:

\section{Year 4 CBE programme:}

- Split students in smaller sub-groups (of 5-6) when paying home visits.

- Execute the programme in newly selected kampongs.

\section{Year 6 CBE clerkship}

- Provide a study guide including the learning objectives.

- Explain the learning objectives at the start of the clerkship.

- Substitute lectures at community sites with interactive sessions, problem-based learning, and practical work in the community.

- Have small groups of students working on the management of specific tasks of the PHC centre instead of the full group studying the management of the PHC centre as a whole. 
- Provide students with unsorted instead of tabulated patient data to study the management of the PHC centre.

- Adjust the target population to be studied (e.g. the number of households to be visited) to the time students have available.

- Devote more time to working in the community at the expense of working in the municipality hospital.

\section{DISCUSSION}

Many comments by students on MFDU's CBE programme confirmed the conclusions on weaknesses previously drawn by us based on comparison of the CBE programme on paper and in action. ${ }^{13}$ No student comment was recorded that contradicted our previous conclusions. In theory such finding could hint at a bias introduced by the person who executed the participatory observations and moderated the FGD's. The principal investigator (TNK) could have ignored student comments deviating from her own observations and opinion or students could have felt inhibited to share deviant comments with their peers and the participating observer or FGD moderator. However, the principal author took particular care not to give her opinion on the programme in which the students were participating, and in the FGD's In addition the students were assured of anonymous and confidential handling of their comments. We therefore assume the students" comments included in this study to be representative and reliable.

It may be noted that only negative comments about the CBE programme were referred to in this report. Some students also shared positive comments about the programme, but these were far less frequently encountered than negative comments. As a consequence, and given our aim to formulate recommendations for improvement of 
MFDU's CBE programme, we here exclusively concentrated on negative comments. The students' comments added to our detailed understanding of the CBE programme in action and consequently increased the depth of our evaluation. Students' suggestions for improvement of the CBE programme have been incorporated in our below recommendations to MFDU.

\section{Final evaluation of MFDU's CBE programme}

MFDU has created adequate partnerships with the regional health care system and local authorities to enable CBE programmes for its students. A total of 12 weeks in the curriculum is reserved for CBE. In practice this period was subdivided in one two-week subunit in year 4 and five one- or two-week subunits plus an examination week in year 6. Subunits were not fitted into a conceptual outline for the CBE programme. Subunits matched corresponding objectives specified in MFDU's description of the $\mathrm{CBE}$ programme. However, we felt one of these objectives - "to understand the management of a secondary hospital and the referral system" - not to fit a CBE programme.

Almost half of the time available for $\mathrm{CBE}$ was used for formal instruction. Lectures were signalled by the students often to be repetitions of lectures already given earlier in the curriculum. Due to the short period available for field work in the community students lacked time to jointly with community members decide on health problems to be tackled, to provide feedback to the community after determining the impact of their interventions, and to prepare follow-up by the next student cohort. These weaknesses make the CBE programme vulnerable to "community exhaustion". In the year 4 CBE programme and in weeks 4 and 5 of the CBE clerkship this stage seemed to be reached. Furthermore, the work agendas of participating health centres (i.e. to 
implement government programmes) interfered with MFDU's objective to enable students to manage community health problems identified by themselves.

Supervision of the students during the CBE programme was often observed to be quantitatively less than scheduled. This was only commented on by the students in relation to their assessment in the year 4 programme.

Little attention was paid to assessment of individual students in field work. Assessment was often only based on supervisors" impressions, profiling by some students in plenary sessions and marks for reports submitted by a group of students. Programme evaluations were never conducted, nor did the planning group for the $\mathrm{CBE}$ programme convene since 1991 to discuss possible improvements in the programme.

\section{Suggestions for improvements}

Based on the evaluation of MFDU's CBE programme reported here and in an earlier paper, ${ }^{13}$ we arrived at the following suggestions for improvement of that programme. Most of MFDU's objectives for its CBE programme, and perhaps even some more objectives adopted from our generic list of objectives, ${ }^{12}$ could be met in a more integrated CBE programme with a larger part of the students 'time spent on activities with the community. A link could be created between the CBE programme in year 4 and the CBE clerkship in year 6 , e.g. by having students perform a "community assessment" in year 4 and arranging for them to return to the same community for follow-up in year 6 .'

In the year $6 \mathrm{CBE}$ clerkship students must interact with the community to identify the community's felt health needs, to take joint 
decisions on potentially useful interventions, evaluation of the activities and to provide feedback. If this cycle cannot be finished by one group of students, provisions should be made for a succeeding student group to complete it. ${ }^{17}$ Care should be taken to timely shift the programme to newly selected communities to prevent "community exhaustion". 18

More attention should be given to assessment of the students' individual contributions in the CBE programme. Evaluation of students by community members and peers are methods suggested by others but not yet employed by MFDU. ${ }^{19}$ Questionnaires should be designed to evaluate perception of the CBE programme among students, faculty and community representatives and the outcomes should frequently be discussed in MFDU to adapt the programme where necessary.

\section{CONCLUSION}

Application of Coles \& Grant's method for curriculum evaluation to the CBE programme of MFDU revealed shortcomings in its design and implementation. Combination of the outcomes of such programme evaluation with a comparison of MFDU's objectives for its CBE programme with a list of generic objectives for CBE programmes recently developed by us, $^{12}$ yielded concrete suggestions could be formulated for improvement of MFDU's CBE programme.

\section{ACKNOWLEDGEMENT}

We are grateful to MFDU's class of 1997 students for participating in FGD's and to Hastaning Sakti, MSc for verifying coding of the students" comments recorded in weeks 4 and 5 of the CBE clerkship and during FGD's. 


\section{REFERENCES}

1. Feletti G, Ja'afar R, Joseph A, Magzoub M, McHarney-Brown C, Omonisi K, Refaat A, Wachs J, Schmidt HG. Implementation of Community-Based Curricula. In: Schmidt HG, Magzoub M, Feletti G, Nooman Z, Vluggen P, eds. Handbook of Community-Based Education: Theory and Practices. Maastricht: Network Publications. 2000;147-199.

2. Nicholson S, Osonnaya C, Carter YH, Savage W. Hennessy E, Collinson S. Designing a community-based fourth-year obstetrics and gynaecology module: an example of innovative curriculum development. Medical Education 2001;35:398-403.

3. Wallace P, Berlin A, Murray E, Southgate L. CeMENT: Evaluation of a regional development programme integrating hospital and general practice clinical teaching for medical undergraduates. Medical Education 2001; 35: $160-166$.

4. Anderson ES, Lennox AI, Petersen SA. Learning from lives: A model for health and social care education in the wider community context. Medical Education 2003;37:59-68.

5. Illife $S$. All that is solid melts into air - the implications of community-based undergraduate medical education. British Journal General Practitioners 1992:42:390-393.

6. Mash B, Villiers M. Community-based training in family medicine - a different paradigm. Medical Education 1999;33:725-729.

7. Kuo AA, Slavin SJ. Community-based education. Is the effort worth it? Medical Education 2001;35:315-3116.

8. Musal B, Aksakoğlu G, Uçku R. Community-based education programme of Dokuz Eylül School of Medicine. Education for Heallh 2003;16:218-221.

9. Coles CR, Grant JG. Curriculum evaluation in medical and health care education. Medical Education 1985;19:405-422.

10. Nelson M, Jacobs $\mathrm{C}$, Cuban L. Concepts of Curriculum. Teaching and Learning in Medicine 1992;4:202-205.

11. Remmen R. Quality and evaluation in medical education. In R. REMMEN: An Evaluation of Climical Skills Training at the Medical School of the University of Aniwerp. Antwerpen: thesis. 1999. 
12. Kristina TN, Majoor GD, Van der Vleuten CPM. Defining generic objectives for community-based education in undergraduate medical programmes. Medical Education $2004 ; 38: 510-521$.

13. Kristina TN, Majoor GD, Van der Veuten CPM. Does CBE come close to what it should be? $A$ case study from the developing world Evaluating a programme in action against objectives on paper. Education for Health; $2005 ; 18: 194-208$

14. Dignan MB. Measurement and Evaluation of Health Edwcation. Springfield, IL: Charles Thomas Publisher. 1989

15. Morgan DL, Scannell AU. (1998). Planming Focus Groups. Thousand Oaks, CA: Sage Publications. 1989

16. Krueger RA, King IA. Involving Communty Members in Focus Groups Thousand Oaks, CA: Sage Publications. 1998

17. Williams RL, Reid SJ, Myeni C, Pitt L, Solarsh G. Practical skills and valued community outcomes: The next step in community-based education Medical education 1999:33:730-737

18. Joseph A, Abraham S. Making community-based education programs sustainable? Education for Healh 2003:16:129-132.

19. Magzoub M.E, Schmidt HG, Abdelmameed AA, Dolmans D, Mustafa SE. Student assessment in community settings: A comprehensive approach. Medical Education 1998;32:50-59. 


\title{
Comparison of a community-based education programme executed with and without active community involvement
}

\begin{abstract}
AIM. The aim of this study was to evaluate the applicability of a previously designed set of generic objectives for community-based education (CBE) emphasising community involvement.
\end{abstract}

METHODS. The study was designed as a non-blinded randomised trial. Experimental and conventional groups of students following CBE programmes either closely or weakly matching the set of generic objectives were compared. Student groups were subjected to passive participatory observation. Students evaluated their programmes through questionnaires. Impact of the students' interventions was assessed by community compliance. Community perception of the programmes was evaluated through structured interview using questionnaires with community representatives.

RESULTS. Students in experimental groups appreciated their programme more than students in conventional groups. High compliance and appreciation were recorded in communities hosting the modified programme. Most students in conventional groups judged their posting negatively particularly due to the many households to be visited. Health interventions performed by conventional groups lacked co-operation between students and the community. Communities hosting conventional groups felt their health needs hardly to be discussed and addressed.

CONCLUSION. Apart from the methodological limitation of this study, modifications of an existing CBE programme to better match a set of 
generic $C B E$ objectives emphasising community involvement positively impacted on programme outcomes and appreciation by students and hosting communities.

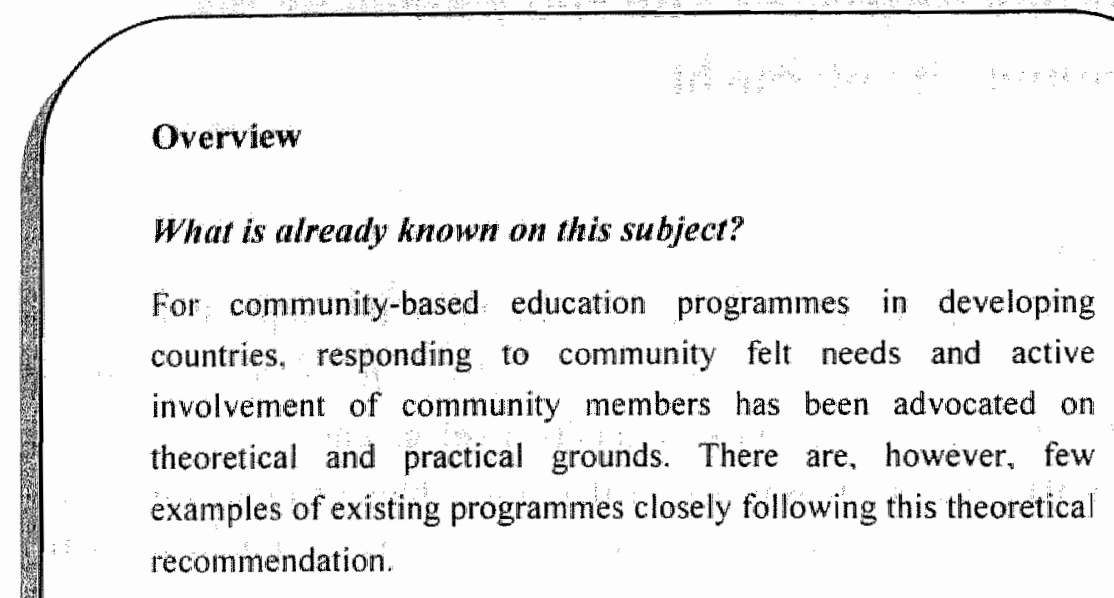

\section{What does this study add?}

This study presents a comparison at the same medical faculty between a CBE programme unresponsive to the community's felt health needs and a variant modified on the basis of a set of generic objectives for $\mathrm{CBE}$ programmes advocating strong responsiveness. Outcomes of the modified programme included better student and community appreciation, better student performance, and high community compliance with implemented health interventions.

\section{Suggestion for further research}

Further specification of the conditions for effective $\mathrm{CBE}$ programmes in developing countries, like minimum time span, key resources, minimal funding, effects after different time elapsed, etc. 


\section{INTRODUCTION}

Community-based education (CBE) is an educational approach which aims to prepare students for future professional work at community level.' A community-based activity is one that takes place within a community or in any of a variety of health services settings at the primary and secondary care level. ${ }^{2}$ CBE provides students with opportunities to learn about community health problems, and concomitantly to apply their knowledge and skills in provision of health services to that community. ${ }^{3} \mathrm{CBE}$ programmes also have the potential to provide public health experiences for medical students by assisting the community to identify their priority health needs and to implement interventions such as health promotion and disease prevention. ${ }^{4}$

There is a growing tendency to include CBE in undergraduate medical education. In Africa and Asia CBE took off in the nineties ${ }^{5-8}$ whereas in Britain and the USA only recently medical schools introduced $\mathrm{CBE}$ in their curricula. ${ }^{9-11}$ Active participation by the local community in the identification of health needs and the design of infrastructure of health services has been strongly advocated in the development of CBE programmes. ${ }^{12-14}$ However, quite often community involvement is weak or suffers from negligence and inappropriate approaches. ${ }^{15.16}$ Particularly in developing countries the relationship is often lopsided: the community 'partner' may assist with planning and operation of the educational activity but receives little in return, and this lack of a true partnership may be seen as a shortcoming of many CBE programmes. ${ }^{16}$ Initially inviting the community to share its problems and expectations will assist to make service-learning experiences profitable for both students and community and add to the sustainability of the programme. ${ }^{17}$ 
Recently, we developed a set of generic objectives for CBE in undergraduate medical programmes particularly tuned to developing countries. Starting from perceived community health needs, we emphasised co-operation of the students with the community to promote its mobilisation and empowerment (Table 1 ). ${ }^{18}$ In this study we applied these objectives to a two-week part of the CBE programme of the Medical Faculty of Diponegoro University (MFDU) in Semarang, Indonesia. In the first four years of MFDU's curriculum some lectures and practicals are relevant as preparation for $\mathrm{CBE}$. The school has two slots for $C B E$ in its curriculum: two weeks in year 4 to study family health problems in an urban area, and 10 weeks in year 6 referred to as the CBE clerkship. ${ }^{19}$ In this CBE clerkship students are posted for two weeks in a rural area to identify and solve community health problems. In the remaining eight weeks students are trained in the management of a Primary Health Care (PHC) centre, a secondary hospital, emergency cases, and urban community health problems.

MFDU's two-week CBE programme within the CBE clerkship was found not to be based on the community"s perceived health needs and students activities were rarely evaluated or followed up. Also the students themselves felt they had not addressed the actual health needs of their hosting community. ${ }^{20}$ In this study an attempt was made to remediate these weaknesses by designing a modified programme matching our set of generic CBE objectives as closely as possible.

Our research questions were: 1) What is the impact of such modified CBE programme on the co-operation between students and the community? 2) What is the impact on community compliance? and 3) How is such an modified programme appreciated by students and community members? A positive outcome of this experiment would add to the validation of our set of generic objectives for $\mathrm{CBE}$. 
In co-operation with the community, graduates are able to:

1. identify health problems related to the given circumstances

2. determine incidence and prevalence of disease in the community

3. invent realistic solutions for identified health problems

4. collaborate with professionals from other disciplines and other related sectors to solve identified health problems

5. mobilise the community for health interventions

6. design and implement a health intervention, and to analyse the results

To provide health education to the com munity, graduates have knowledge on:

7. adequate nutrition

8. life style-related health risks in the community (e.g. smoking, alcohol and drug abuse, promiscuity, lack of physical activities, etc.)

9. environment-related health risks (e.g. contagious diseases, water and vector borne diseases, pollution)

10. occupational health,

and are able to:

11. design and transmit health education sessions

12. train community health workers in health education

13. evaluate the effectiveness of health education

To reduce inequity in access to health services, graduates are able to:

14. assess availability of health services to the community

15. identify barriers to health care utilisation by the community

16. monitor effectiveness and efficiency of community health services

17. invent realistic strategies to improve community access to health services

18. work in a variety of community health care settings (e.g. primary health care centres, district hospitals, Maternal and Child Health care units, etc.) and to provide preventive, primary curative, and emergency care.

19. manage a primary care unit and to sustain health administration

20. judge which patients need to be referred

21. participate in health teams (with e.g. nurses, midwives, community health workers, etc.)

* Derived from a framework specifying possible community health needs, potential assistance by students and competencies needed in students to lend such assistance (Kristina et al., 2004). 


\section{MATERIALS AND METHODS}

A non-blinded, randomised control study was designed. A full class of 141 final year medical students was stratified according to sex and randomly allocated to six groups of $20-25$ students. Groups following the modified CBE programme were designated experimental groups and those following the unmodified programme conventional groups. The first investigator explained to the students about this study and asked for informed consent before randomization. Two groups (50 students) were arranged to pilot the research methodology and excluded from further analysis; the remaining four groups (91 students) were included in the study. The outcomes of these pilots were used to optimise the programme evaluation questionnaire and to equalise the study load for

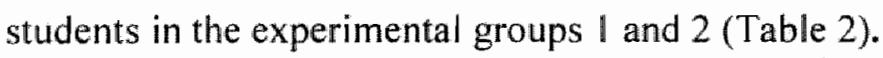

Table 2. Results of randomization villages for Experimental groups.

\begin{tabular}{ccccccc}
\hline \multirow{2}{*}{ Experiment } & \multicolumn{2}{c}{ Experimental groups } & \multicolumn{3}{c}{ Conventional groups } \\
\cline { 2 - 7 } & Code & $\begin{array}{c}\text { PHC } \\
\text { centre }\end{array}$ & Village & Code & $\begin{array}{c}\text { PHC } \\
\text { centre }\end{array}$ & Village(s) \\
\hline \multirow{2}{*}{ Pilot } & $\mathrm{PEI}$ & $\mathrm{D}$ & $\mathrm{J}$ & $\mathrm{PCl}$ & $\mathrm{E}$ & $\mathrm{K}$ \\
& $\mathrm{PE2}$ & $\mathrm{D}$ & $\mathrm{J}$ & $\mathrm{PC} 2$ & $\mathrm{E}$ & $\mathrm{L}$ \\
$\mathrm{A}$ & $\mathrm{A} 1$ & $\mathrm{E}$ & $\mathrm{M}$ & $\mathrm{Cl}$ & $\mathrm{D}$ & $\mathrm{N}, \mathrm{O}$ \\
& $\mathrm{A} 2$ & $\mathrm{E}$ & $\mathrm{M}$ & $\mathrm{C} 2$ & $\mathrm{D}$ & $\mathrm{P}$ \\
$\mathrm{B}$ & $\mathrm{B} 1$ & $\mathrm{D}$ & $\mathrm{Q}$ & $\mathrm{C} 3$ & $\mathrm{E}$ & $\mathrm{R}-\mathrm{X}$ \\
& $\mathrm{B} 2$ & $\mathrm{D}$ & $\mathrm{Q}$ & $\mathrm{C} 4$ & $\mathrm{E}$ & $\mathrm{Y}, \mathrm{Z}$ \\
\hline
\end{tabular}

* Villages for Conventional group were chosen by the head of PHC centre

Experimental and conventional groups worked in different villages in the catchment's areas of different PHC centres (D and E). The experiment was conducted twice to increase the reliability of data 
collected (experiments A and B). In experiment B the PHC centres hosting experimental and conventional groups were interchanged to reduce location bias. All villages had previously received students for the unmodified programme. Target villages for conventional groups were selected as usual by the head of the PHC centre; for experimental groups target villages were selected at random from the available 10 (experiment A) or 5 (experiment B) villages. One faculty member was trained to supervise the experimental groups; a colleague routinely supervised conventional groups following the unmodified programme.

Experimental group Al interviewed key persons in the community to collect information on the community's perceived health needs. Students discussed their findings with their supervisor and the head of the PHC centre to select needs suitable to address. Students` suggestions with respect to the selected health needs were reported to the head of the PHC centre. Group A1's final reports were discussed with the succeeding group A2, one day prior to their departure to the village. Group A2 discussed the health problems identified by group AI with community members and proposed solutions feasible in relation to the community"s resources. Group A2 verified and followed up on the findings of group $\mathrm{Al}$, and evaluated the result of their own work and that of the preceding group $\mathrm{A} \mid \mathrm{b}$ by assessing community compliance. The second experiment (B) was conducted as experiment A, but in another village.

According to the unmodified programme, conventional groups received assignments matching government health programmes from the head of the PHC centre. On site each of the four conventional groups (Table 2) was divided in subgroups to work with health providers responsible for a certain programme. Within such programme, students had to identify a health problem, propose solutions for the selected problem, and implement one of the proposed solutions. 


\section{Data collection and analysis}

The outcomes of the programmes were evaluated on a number of variables.

First, student activities and community participation were monitored by passive participatory observation in which the observers followed the students activities without interfering or giving any suggestion. ${ }^{21}$ Two research assistants alternatingly observed experimental and conventional groups; relevant comments by students and community members were recorded in writing. The first author co-observed experimental as well as conventional groups. Community compliance was chosen as a parameter for the impact of activities by experimental groups and calculated as the percentage of community units who followed students advice concerning their identified health problem. Since conventional groups usually did not evaluate the impact of their interventions, ${ }^{19}$ community compliance in the unmodified programme was only determined if the students were assigned to perform an evaluation.

Second, to evaluate student perceptions, students were asked to fill in a programme evaluation questionnaire at the end of their CBE posting. They were promised confidentiality and assured that their participation would not affect their academic record. Students were requested to rate 22 statements on a 4-point Likert scale (4=totally agree, $3=$ tend to agree, $2=$ tend to disagree, and I=totally disagree) and to answer some openended questions.

Third, student competence was assessed by comparing mean student marks of experimental and conventional groups. Marks were given independently by the two supervisors for each student, calculated on the basis of the students' individual written reports, oral presentations, and their supervisor's records of daily activities. The supervisors were not blinded to the group of students. 
Fourth, two weeks after each experiment, research assistants assessed community perceptions using questionnaires in home visits to selected community members. Community members were stratified according to their status in the community and 30 were randomly selected from each area under study. This procedure yielded community response groups encompassing 4 community leaders, 7 health workers, 2 community organisation representatives, and 17 common community members.

Quantitative data were analysed using SPSS version 10 . The nonparametric Mann-Whitney U-test was applied for comparison of ordinal data and students" marks; the chi-square test was used for proportional data. For comparison of achievement of learning objectives between subgroups of experimental and conventional groups, two-tailed $P$-values were used with $p<0.01$ as the criterion for statistical significance.

Qualitative data were interpreted according to the format of a planned conceptual investigation. ${ }^{22}$ First, data were organised by linking student activities with recorded comments, community participatory activities, and outcomes of student interventions. Second, frequently expressed comments and frequently observed activities were coded as key points. Finally, key points were grouped into categories to develop themes. ${ }^{23}$ Students ${ }^{2}$ comments and answers to open questions in the questionnaire were initially analysed by the first author. To verify the reliability of this analysis, a volunteer (a resident with experience in qualitative studies) was asked to also code the students' comments and answers to open questions. Original coding by the first author was compared with coding by the volunteer; differences emerging (in 3 out of 26 codings) were discussed to reach consensus. 


\section{RESULTS}

We will discuss the results for each of the variables that were investigated.

Student activities, community participation, and community compliance

\section{Experimental groups}

Based on community felt needs, inadequate housing and sanitation, health risks for fisherman and furniture labourers, undernourished toddlers, and low utilisation of the village health services were selected as suitable problems. In the two weeks available each student had to visit approximately 45 households. Group A1 was divided into three subgroups. Subgroup I provided education to improve housing and sanitation and attended undernourished toddlers; subgroup 2 provided health education to fisherman and furniture workers; and subgroup 3 investigated reasons for under-utilisation of village health services.

Also group A2 was divided in three subgroups to verify and follow up on the findings of group Al. Actions undertaken included construction of public toilets, screening of undernourished toddlers for tuberculosis (TB), first aid training for fishermen and furniture labourers, and promotion of the village health centre by arranging for assistance by a medical doctor. Compliance was $65 \%$ with respect to households inserting glass roofs on their houses to reduce the risk of upper respiratory tract infections and $\mathrm{TB}$, and $71 \%$ for covering their toilet pits to prevent foul smell and spreading of germs by insects. Low compliance $(3 \%)$ was observed among the furniture labourers with respect to wearing masks to prevent airway pollution. 
The second experiment (B) was conducted as experiment A, but in another village. Similar health problems and needs were found, but also some additional health problems like Dengue Haemorrhagic Fever (DHF) and TB. High levels of community compliance were also observed in this experiment: $80 \%$ for households placing glass roofs on their house; $78 \%$ for putting covers on their toilet pits; and $73 \%$ for cleaning the environment to prevent DHF. Assessing possibly changed utilisation of village health centres was not accomplished due to lack of time.

\section{Conventional groups}

Students of conventional group $\mathrm{Cl}$ were assigned to execute government programmes like assessing cases of malaria. DHF. TB, and the nutritional status of toddlers. Group $\mathrm{C} 2$ assessed health behaviour in the community, environmental health in public places, and co-operated with teachers in school health programmes. Both groups gave education to health workers and the community. Group C3 collected data about the availability of potable water and adequate sanitation in one village and evaluated drug dispensaries in six villages. The students found many examples of inadequate sanitation, which was addressed by dissemination of an information leaflet. Groups CI-C3 suggested the PHC centre to follow up on their findings. Group $\mathrm{C} 4$ was assigned to mobilise the community to clean the environment for prevention of DHF.

Students in conventional groups each had to visit about 200 households in two weeks. Students implemented their interventions without any discussion with the community about the relevance of these interventions and their findings were not fed back to the community. With the exception of group C4's activity (yielding $23 \%$ compliance), the impact of students" interventions was not evaluated. 


\section{Student perceptions}

A comparison of students' opinions in experimental and conventional groups is presented in Table 3. Students in the experimental groups scored significantly higher than those in conventional groups on $2 / 3$ items scoring general aspects of the programme; on $4 / 5$ items addressing experiences in the community , and on $1 / 3$ items addressing teamwork.

Students' perceived achievement of learning objectives matching the set of generic CBE objectives was also explored (Table 4). Students in the pooled experimental group AI + Bl indicated significantly higher achievement than pooled conventional groups on $3 / 10$ objectives, and students in experimental group $\mathrm{A} 2+\mathrm{B} 2$ on $5 / 10$ objectives.

Students' answers to open-ended question and students comments during training

\section{Experimental groups}

In general the students felt welcomed by the community, finding most community members enthusiastic and ready to cooperate, though critical to the students' health interventions. In mobilising the community, the students met no significant barriers and they appreciated the role of community leaders in that respect. Students also appreciated the continuation of activities in the community undertaken by successive groups. Critical comments by students regarded costs of their own transportation. lack of budget for interventions, varying learning experiences, and lack of time. 


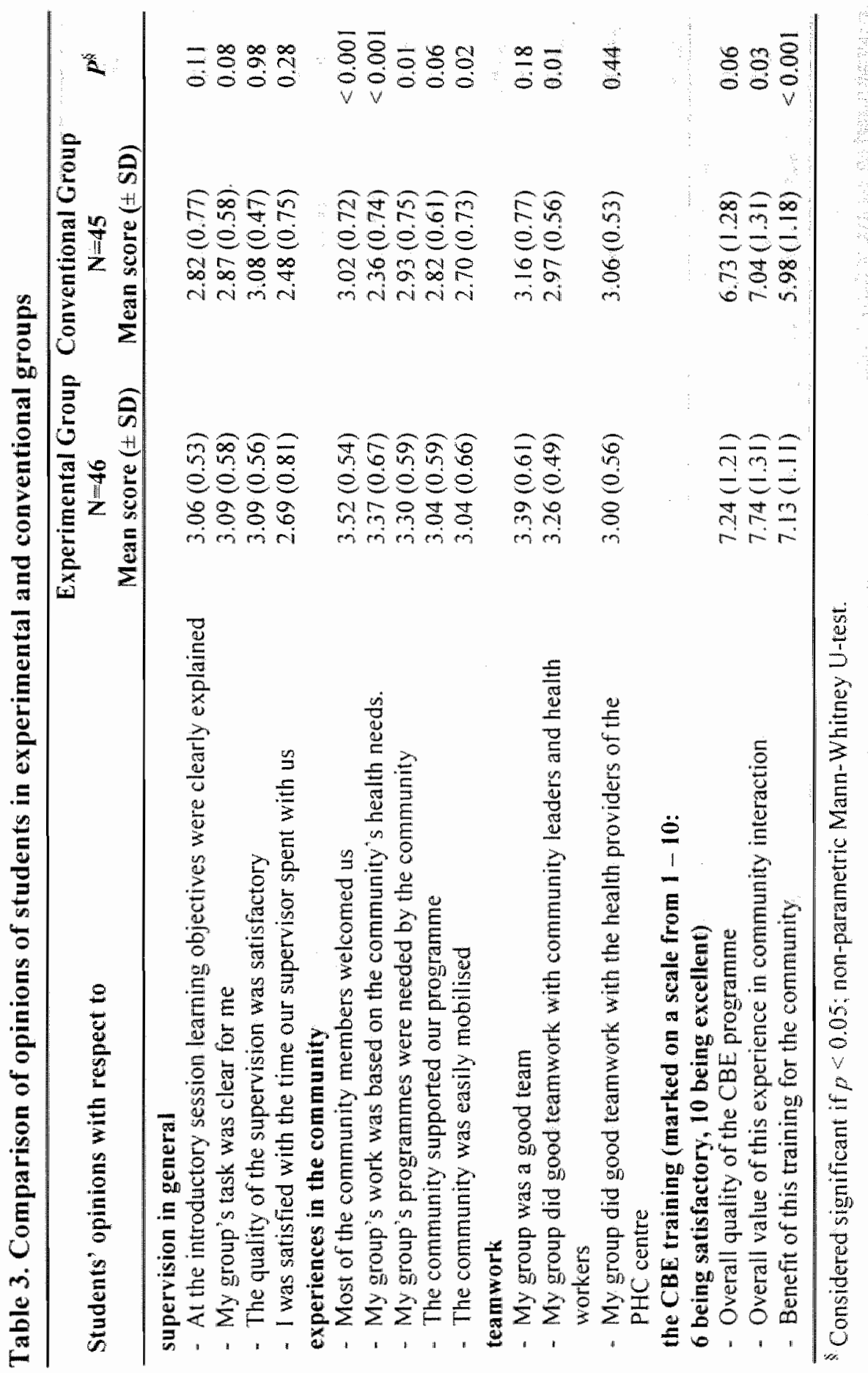




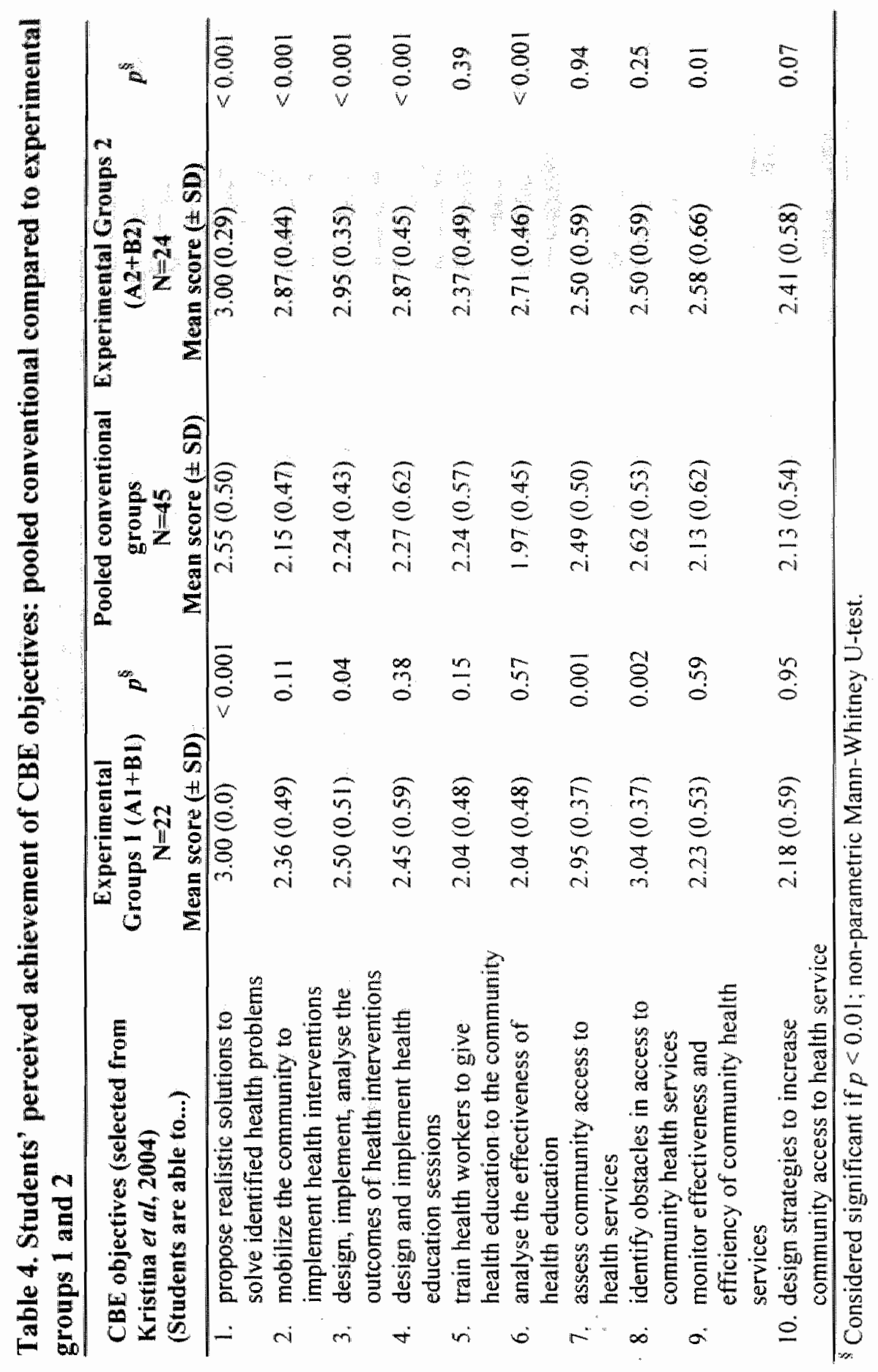




\section{Conventional groups}

Most students evaluated the unmodified posting negatively as they considered it exhausting, due to the many households to be visited. Students also felt being used by the PHC centre, which neglected their learning process and only seemed interested in data collection. Many students felt the community to be annoyed because it had experienced similar student activities without any reward or follow-up by the students and the PHC centre. Students also complained about costs of transportation, lack of budget for interventions, and the restricted time available.

\section{Student competence}

Students marks for the CBE programme ranged between 77 and 84. Eleven students in the experimental group, but only one student in the conventional group received marks over 80 . The mean students ${ }^{*}$ mark for the pooled experimental group $\mathrm{A}+\mathrm{B}$ of $79.7 \mathrm{l}$ ( $\mathrm{SD} \pm 1.7: 95 \% \mathrm{Cl}$ : $79.17-80.25)$ was significantly higher $(p=0.001)$ than the mean mark of 78.57 for the pooled conventional group ( $\mathrm{SD} \pm 1.3 ; 95 \% \mathrm{Cl}: 78.18-$ 78.97). The inter-rater reliability for the two supervisors was satisfactory $(r=0.89)$.

\section{Community perceptions}

Community opinions about the unmodified and moditied CBE programmes are presented in Table 5. The proportion of community representatives who agreed that the students had responded to their felt needs was significantly higher for the modified programme than for the unmodified programme. Community representatives experiencing the modified programme expressed their satisfaction with the students" activities and recommended the same activities for future groups in other places. Most community representatives in villages visited by conventional groups were not (or 'not really') satisfied with the student activities. 
Table 5. Comparison of community opinions on the work of experimental and conventional groups

\begin{tabular}{|c|c|c|c|c|}
\hline Item & $\begin{array}{c}\text { Community } \\
\text { opinion }\end{array}$ & $\begin{array}{c}\text { on work by } \\
\text { experimental groups } \\
(30 \text { respondents; } \%)\end{array}$ & $\begin{array}{c}\text { on work by } \\
\text { conventional groups } \\
\text { (30 respondents; \%) }\end{array}$ & $p^{*}$ \\
\hline $\begin{array}{l}\text { Students } \\
\text { discussed our } \\
\text { health needs with } \\
\text { us }\end{array}$ & $\begin{array}{c}\text { yes } \\
\text { no } \\
\text { don't know }\end{array}$ & $\begin{array}{c}48.33 \\
1.67 \\
0\end{array}$ & $\begin{array}{c}5 \\
45 \\
0\end{array}$ & $<.001$ \\
\hline $\begin{array}{l}\text { Students } \\
\text { responded to our } \\
\text { health needs }\end{array}$ & $\begin{array}{c}\text { yes } \\
\text { no } \\
\text { don't know }\end{array}$ & $\begin{array}{l}45 \\
0 \\
5\end{array}$ & $\begin{array}{c}5 \\
40 \\
5\end{array}$ & $<.001$ \\
\hline $\begin{array}{l}\text { Students" } \\
\text { activities met our } \\
\text { expectations }\end{array}$ & $\begin{array}{c}\text { yes } \\
\text { no } \\
\text { don't know }\end{array}$ & $\begin{array}{c}28.34 \\
8.33 \\
13.33\end{array}$ & $\begin{array}{c}20 \\
25 \\
5\end{array}$ & 0.02 \\
\hline $\begin{array}{l}\text { Our community } \\
\text { is now more } \\
\text { aware of its } \\
\text { health risks }\end{array}$ & $\begin{array}{c}\text { yes } \\
\text { no } \\
\text { don't know }\end{array}$ & $\begin{array}{c}28.34 \\
0 \\
21.67\end{array}$ & $\begin{array}{l}31.67 \\
8.33 \\
10\end{array}$ & 0.02 \\
\hline $\begin{array}{l}\text { Our community } \\
\text { is satisfied with } \\
\text { the students" } \\
\text { activities }\end{array}$ & $\begin{array}{c}\text { yes } \\
\text { no } \\
\text { not really }\end{array}$ & $\begin{array}{l}33.89 \\
16.95\end{array}$ & $\begin{array}{l}6.78 \\
15.25 \\
27.13\end{array}$ & $<.001$ \\
\hline $\begin{array}{l}\text { Students did } \\
\text { advance oul } \\
\text { community"s } \\
\text { health }\end{array}$ & $\begin{array}{c}\text { yes } \\
\text { no } \\
\text { don't know }\end{array}$ & $\begin{array}{c}41.67 \\
0 \\
8.33\end{array}$ & $\begin{array}{c}11.67 \\
25 \\
13.33\end{array}$ & $<.001$ \\
\hline
\end{tabular}

* Considered significant if $p<0.05$; chi-square test 


\section{DISCUSSION}

Ensuring successful partnership of an educational institution with the community requires active community involvement in all aspects of the programme. However, few medical schools involve the community in the process of programme planning and evaluation. ${ }^{24}$ Musal (2003) reported that in spite of students' eagerness to learn from and to resolve community health problems, community participation is still far from being satisfactory. ${ }^{25}$ For MFDU's unmodified CBE programme, active community participation was not even stated. Substitution of its CBE programme by a modified version more closely matching a previously designed set of generic CBE objectives emphasising community involvement yielded more active community participation and more positive evaluations by students and community representatives. Community compliance in the modified programme was high, but could not be compared with compliance achieved in the unmodified programme, because only one group actively mobilised the community.

On average students in experimental groups attending the modified programme claimed better achievement of the relevant generic CBE objectives than students in conventional groups attending the unmodified programme. However, the experimental groups still felt not to have achieved all learning objectives. This may be due to the fact that some activities performed by these groups did not prompt for mobilisation of the community or did not allow for evaluation of the impact of the students" interventions due to lack of time.

Target sample of households to be visited by experimental groups was adjusted to the limited time available. On the other hand, the conventional groups had to pursue large samples of households for the government health programmes, and performed interventions without evaluation. Thus, experimental groups may claim better achievement of 
objectives than conventional group because the later may have lacked of time to address those generic CBE objectives. Accordingly, the positive result of this study was influenced by the weaknesses of the unmodified programmé.

Students in experimental groups appreciated their CBE programme better than students in conventional groups. It was particularly encouraging that students following the modified programme scored higher than their peers in the conventional programme on 4 out of 5 questions addressing their experiences with the community. Important questions here showing significantly different responses were the link between the work of the student groups and community's health needs, and the importance of the group's programmes for the community.

Although precautions were taken to avoid observer bias, some influence on the results of this study cannot be ruled out. The first author and the two independent observers (research assistants) took care to pay equal attention to student activities in experimental and conventional groups. However, stronger interest of the first author in the outcomes of the modified programme may have influenced the results of the experimental groups. ${ }^{26}$

Another potentiaل bias is a possible preference of the students. supervisors for the modified or the unmodified programme. Supervisors" preference for the modified or the unmodified programme may have indirectly influenced the students' evaluation of the programme attended. A further potential bias is that students were assigned to their placements in a non-blinded fashion, which may have yielded higher marks of students in experimental groups. ${ }^{27}$ Lastly, the mere participation in the modified CBE programme may have elicited a more positive evaluation by participating students unrelated to its merits, a bias known as the Hawthorne effect. ${ }^{28}$ 
Apart from the above possible limitations of our study, we take the outcomes to indicate the practical applicability of our set of generic CBE objectives to structure $\mathrm{CBE}$ programmes. Although this paper describes the application of our list of generic CBE objectives in the context of rural communities in Java, Indonesia, we presume this set of generic objectives to be applicable in any developing country setting.

\section{ACKNOWLEDGEMENTS}

We are most grateful to Nurkukuh $M D$ and Bambang Hariyana MD, supervisors of MFDU's CBE clerkship, for their valuable suggestions and participation in this experiment. We thank Helmia Farida MSc for cross-checking codification of students" comments and answers to open questions, and Hidayat Sulistyo MD and Hendi Rastiawan MD for conscientious observation of students' activities.

\section{ETHICAL APPROVAL}

There was no formal approval for the study by an ethics committee.

\section{REFERENCES}

1. Schmidt HG. Preface. In: Schmidt HG, Magzoub M, Felleti G, Nooman Z, Vluggen P, eds. Handbook of Community-Based Education: Theory and Practices. Maastricht: Network Publications 2000;7-8.

2. World Health Organisation. Community-Based Education of Health Personnel. [WHO Study Group Report.] Geneva: WHO 1987.

3. Magzoub ME, Schmidt HG. A taxonomy of community-based education: Academic Medicine 2000;75:699-707.

4. Bligh J. Tomorrow's Doctors: extending the role of public health medicine in medical education. Medical Education 2002;36:206-207. 
5. Ayedun BA Community-based experience and service (COBES) programme. Annals Communily Oriented Education 1992;5:61-67.

6. Tsikirayi CMR, Todd CH. Community-based medical education and curriculum change: The field attachment programme of the school of medicine of the University of Zimbabwe. Annals Community-Oriented Educarion $1992 ; 6: 43-52$.

7. Jira $\mathrm{C}$. Community-based team training programme at Jimma Institute of Health Sciences. Annals Community-Oriented Education 1994:7:131-138

8. Achananuparp $\mathrm{S}$. The Ramathibodi community medicine programme: An undergraduate traming of GP's in Thailand. Annals Community-Oriented Educaion 1995;8:147-152.

9. Davison H, Capewell S, Macnaughton J, Murray S, Hanlon P, Mc. Ewen J. Community-oriented medical education in Glasgow: Developing a community diagnosis exercise. Medical Edwation 1999:33:55-62.

10. Sullivan MO, Martin J, Murray E. Students perception of the relative advantages and disadvantage of community-based and hospital-based teaching: a qualitative study. Medical Education 2000;34:648-655.

11. Ferrari III ND, Cather GA. Community service, learning and the medical student. Eduction for Health 2002;15:222-227.

12. Omotara BA. Padonu MKO, Bassi AP, Amodu MO. Community-based medical education: The University of Maiduguri experience. Annals Commmity-Oriented Edweation 1992:5:41-46.

13. Habbick BF, Leeder SR. Orienting medical education to community needs: A review. Medical Education 1996:30: 163-17|.

14. Nazareth I, Mfenyana K. Medical education in the community-the UNITRA experience. Medical Education 1999:33:722-724.

15. Ezzat E. Role of the community in contemporary health professions education. Medical Edrcation 1995;29(suppl. 1):44-52.

16. Williams RL, Reid SJ, Myeni C, Pitt L. Solarsh G. Practical skills and valued community outcomes: The next step in community-based education. Medical Edroation 1999;33:730-737

17. Olm-shipman $C$, Reed VA, Jernstedt, GC. Teaching children about health, Part 11: The effect of an academic-community partnership on medical students" communication skills. Edrcation for Healih 2003;16:339-347. 
18. Kristina $\mathrm{TN}$, Majoor GD, Van der Vleuten CPM. Defining generic objectives for community-based education in undergraduate medical programmes. Medical Education 2004;38:510-521.

19. Kristina TN, Majoor GD, Van der Vleuten CPM. Does CBE come close to what it should be? A case study from the developing world. Evaluating a programme in action against objectives on paper. Education for Health. 2005; 18:194-208.

20. Kristina TN, Majoor GD, Van der Vleuten CPM. Does CBE come close to what it should be? A case study from the developing world. Students' opinions. Education for Health (Submitted).

21. Adler PA, Adler P. Observational Techniques. In: Denzin NK, Lincoln YS, eds. Handbook of Qualitative Research Thousand Oaks, CA: Sage Publications 1994; 377-390.

22. Patton MQ. Qualitative Evaluation and Research Methods. Newbury Park, CA: Sage Publications 1990.

23. Silverman D. Interpreting qualitative data. Methods for analysing talk text and interaction. Thousand Oaks, London: Sage Publications 2001.

24. Magzoub $M$, Schmidt $H$, llyas $M$, Lewis J. Impact of community-based educational programme (1): Effects on the community. In: Schmidt $H G_{\text {, }}$ Magzoub M, Felleti G, Nooman Z, Vluggen P, eds. Handbook of Community-Based Education: Theory and Practices. Maastricht: Network Publications 2000;375-388.

25. Musal B, Aksakoğlu G, Ucku R. Community-based education programme of Dokuz Eylul School of Medicine. Edmution for Huath 2003:16:218-221.

26. Dorak MT. Bias and confounding. Retrieved on Jaruary 19, 2005. http://dorakmt.tripod.com/epi/bc.html. Last updated on January 14, 2005.

27. Prideaux D. Researching the outcomes of educational interventions: a matter of design. British Medical Journal 2002;324:126-127.

28. Gibbon CTF, Torgerson CJ, Prideaux D. Researching outcomes of educational interventions. British Medical Journal 2002;324:1155. 



\section{Chapter 7}

\section{General discussion}

The general objective of CBE programmes in medical curricula particularly in developing countries is to expand the students" notion of community health problems through their learning, service and research in the community and thereby to improve the health of the community with which the programme is carried out. 'Although the objectives for such CBE programmes must be tuned to local circumstances, ${ }^{2}$ the availability of a set of generic objectives for $\mathrm{CBE}$ programmes would assist medical schools in designing CBE programmes or to compare the objectives of an existing CBE programme with to check whether all important aspects were covered. This thesis focuses on the definition and validation of generic CBE objectives for undergraduate medical education in developing countries. The conceptual framework designed to derive generic $\mathrm{CBE}$ objectives from, and the derived objectives were used as a reference to evaluate an existing CBE programme in a medical school in a developing country and as guidance in the design of a modified CBE programme adjusted to our generic CBE objectives for the same school. The main results of this thesis are discussed in accordance with the research questions.

Research question 1: How to develop a framework for the generation of generic CBE objectives for undergraduate medical programmes?

Table 1 in chapter 2 presents the outcomes of the four consecutive steps taken to develop generic CBE objectives including modifications suggested by and adopted from the expert panel. As presented in the first column of Table 1, six conditions affecting community health were 
identified that lend themselves for improvement by the community in collaboration with students. These conditions are: the availability of safe drinking water, safe sanitation and healthy housing, adequate nutrition, rewarding daily activities, education on health risks, and access to health services. The second column of Table I shows potential student activities in $C B E$ programmes to improve inadequate circumstances identified in the first column. These activities could be clustered as co-operation with the community in identifying and solving community health problems. providing health education to the community and community health workers, and conducting research activities that indirectly contribute to improvement of community access to health services. The third column specifies the competencies required in the students to execute these possible tasks sorted according to three distinguished areas of CBE, i.e. research, training, and service.' To address these competencies, 21 generic objectives for CBE programmes were formulated which were checked against lists of objectives for specific CBE programmes stated in the literature (fourth column of Table 1). Each of the objectives derived from the process described above was also found in at least one of the documented lists of objectives for specific CBE programmes.

The strength of this study lies in the logical sequence of the four steps taken to generate objectives traceably rooted in factors impacting on community health. An international expert panel discussed the draft framework for face validation. Several suggestions were given by this panel to improve the draft framework. For example, with respect to factors influencing community health it was suggested that the students should identify these conditions in consultation with the community in order to define the community's felt needs. Furthermore, in defining students 'tasks to assist the community in improving inadequate circumstances, the expert panel emphasised the need for close cooperation between students and community members. Thus, the generic 
CBE objectives should not only focus on students but also on active community participation. These suggestions are in line with the recommendations for the implementation of $C B E$ programmes as advocated by WHO, i.e. the importance of community involvement in the decision-making and close collaboration with community representatives and, whenever feasible, community members. ${ }^{3}$ Accordingly, most of the panel's suggestions were extensively adopted and inserted in the first and second column of Table 1.

In the literature no detailed elaboration to develop CBE objectives as presented here was detected. However, there is a parallel with the definition of CBE goals departing from a quality improvement perspective. This approach emphasises good relations with patients; clinical management in community practice; management of health and disease in the community; and the practice of improving community health. ${ }^{+}$

An important question is whether the generic objectives for $\mathrm{CBE}$ programmes as derived from our conceptual framework would indeed be supported by medical schools in developing countries. Thus, the framework and the set of objectives presented in this chapter were evaluated by a wider circle of medical schools in developing countries (chapter 3).

Research question 2: What is the perception of medical schools in developing countries toward the developed generic CBE objectives? Will the result of this study yield a validated list of CBE objectives for undergraduate medical training?

In chapter 3, a survey was conducted to validate the set of generic CBE abjectives for undergraduate medical training. Questionnaires were sent to 72 medical schools world wide that were randomly chosen from lists 
of members of The Network: Toward Unity for Health, and non-Network medical schools stratified according to developing countries. The approach to develop the generic CBE objectives and 17/21 of these objectives were perceived as relevant by the respondents. We eventually decided to maintain three out of the four "rejected" objectives based on positive comments by respondents and support in the literature. The objective graduates are able to manage a primary care unit and to sustain health administration' was deleted. Such objective is indeed rarely reported for undergraduate $\mathrm{CBE}$ programmes. ${ }^{5}$ On the other hand, management training has been reported as an objective for postgraduate training. ${ }^{67}$ Thus, we are aware that the CBE objective "graduates are able to manage a primary care unit and to sustain health administration "has to give attention in further studies. We assume that by separating to manage a primary care unit' and 'to sustain administration of primary care unit", we may probably receive different results. Other methods, for example focus group discussions or in-depth interviews with stakeholders, may be applied in such study.

The strength of this questionnaire survey was enhanced by the characteristics of respondents. More than $90 \%$ of the respondents had implemented CBE programmes. Therefore, their comments and suggestion were considered worthwhile in the validation of the generic CBE objectives. This study yielded an amended and validated list of 20 generic $\mathrm{CBE}$ objectives for undergraduate medical training.

Research question 3: Can an established method of curriculum evaluation, combined with the generic CBE objectives for undergraduate medical programmes, be used as a reference for CBE programme evaluation? 
As a case study of the evaluation of a CBE programme, an assessment of the 12-week CBE progranme of the Medical Faculty of Diponegoro University (MFDU) in Semarang, Indonesia is presented in chapters 4 and 5. The comparison between MFDU's CBE programme on paper and in action indicated that this programme was not entirely. implemented as planned. The use of the set of generic CBE objectives as a reference also revealed significant weaknesses of this programme. For instance students' work in the community was not based on joint problem identification with community members and the students' interventions were rarely evaluated. In the study describing 'the curriculum as experienced by the students*, more in-depth information was acquired. The students specifically emphasised the occurrence of 'community exhaustion" and greater benefits of the $\mathrm{CBE}$ programme for the PHC centres and themselves than for the targeted communities.

Thus, when students were posted in urban and rural communities, this evaluation revealed weaknesses similar to those mentioned by Hamad (2000), i.e. the programme's objectives were limited to training, executed as isolated actions, with no follow-up or continuity, and the activities were repeated with little or no concern for the benefits to the community. ${ }^{2}$

Educational institutions should have a mission statement which clearly states their commitment to $\mathrm{CBE}^{8}$ and to improvement of health in the communities where their CBE programmes are carried out.' These commitments should be reflected in the school's curriculum in both duration and timing, and in the labelling of human resources to execute CBE programmes. ${ }^{8}$ As a result, the students activities in $\mathrm{CBE}$ should refer back to this mission. It is necessary not only to determine which specific knowledge, skills, and attitudes should be acquired in the community, but also how these competencies are best developed." 
As the main goal of CBE is to produce physicians who are responsive to community health needs and able to work in rural and underserved areas, ${ }^{10}$ our set of generic CBE objectives (that was created starting from the community's felt health needs) can be used as guidance. to improve the CBE curriculum. The students may follow the steps taken to meet the objectives, whereas the faculty should ensure the students learning through application of appropriate and relevant methods of assessment. ${ }^{2}$

Moreover, it is necessary to introduce systematic evaluation of the CBE programme to monitor its appropriateness and effectiveness ${ }^{13}$; by creating continuity of the $\mathrm{CBE}$ programme $\mathrm{s}^{314}$; by inviting active community participation, by considering several different locations for the CBE activities to avoid community exhaustion, and by sustaining the CBE programme."

A CBE programme must be of clear benefit to both students and the community, which implies that the community must be actively involved in the design of the educational programme. ${ }^{3}$ We found no active community participation in MFDU's CBE programme. In line with our study, Musal (2003) reported for a school in Turkey that in spite of the students" eagerness to learn and resolve community health problems, community participation was still far from satisfactory. ${ }^{15}$ Therefore, following this $\mathrm{CBE}$ programme evaluation, a modified version of MFDU's CBE programme was executed with active community involvement in accord with our set of generic CBE objectives (chapter 6).

To our knowledge; this is the first example in which the model of Coles \& Grant for curriculum evaluation was applied to evaluate a $\mathrm{CBE}$ programme. This study demonstrated that this model, combined with the generic $\mathrm{CBE}$ objectives for undergraduate medical programme, was a 
useful tool to evaluate the CBE programme in MFDU. On the other hand we assume that several medical schools have their own methods to evaluate their CBE programmes. ${ }^{15-17}$ We did not demonstrate whether this model is a better method if compared to other methods of evaluation of $\mathrm{CBE}$ programmes. Further research is suggested in which our evaluation format would be implemented in another medical school that routinely evaluated its $\mathrm{CBE}$ programme using another approach.

\section{Research question 4: What is the impact of a CBE programme matching the generic $\mathrm{CBE}$ objectives on students and the community?}

Chapter 6 of this thesis presents a comparison between a part of MFDU's conventional CBE programme and one modified on the basis of our set of generic objectives for CBE programmes. As usual training, students in the unmodified programme received assignments from the head of the PHC centre to perform government health programmes. In the modified programme, students used our framework and the derived generic CBE objectives as guidance for their activities.

When comparing the outcomes of the unmodified and the modified programme, the modified one resulted in better appreciation and performance by the students. The community was also more appreciative to the students" activities. High community compliance with the implemented health interventions was found in the modified programme. The community in the unmodified programme perceived that their health needs were hardly discussed and addressed. They also criticised the students" activities for being too focused on data collection.

Active participation of the community is a crucial element for the implementation and development of the CBE programme. ${ }^{18}$ However, quite often, their participation is missing or suffering from negligence 
and inappropriate approaches. ${ }^{19}$. The later statement also applied to MFDU's unmodified CBE programme.

The community (including key persons) has valuable knowledge of local needs and should have an ownership of their involvement. ${ }^{20}$ Accordingly, active participation by the local community in the identification of health needs ${ }^{21}$ and involving the community to decide what issues should be addressed will increase the value of communitybased training. ${ }^{10.22}$ The study presented in chapter 6 also indicates that community felt health needs can be used as a starting point to encourage community involvement in $\mathrm{CBE}$ activities.

In conclusion, substitution of a $\mathrm{CBE}$ programme closely matching our generic CBE objectives, which emphasise community involvement, resulted in more active community participation and more positive evaluations by students and community representatives. However, the significant differences in the outcomes as presented in this study are obviously influenced by the weaknesses of the unmodified programme. Thus, the generic CBE objectives should be implemented in other medical schools to corroborate the reliability and generalisability of this study.

\section{Limitations of the studies presented in this thesis}

The studies of this thesis have some limitations. This has been discussed in detail in chapters 2-6. However, there are some additional limitations. In chapter 2, assessment of the face validity of the framework and the derived objectives by an international expert panel was conducted only once, and this is considered a weakness of this study. The survey performed to acquire the perception of a wider circle of medical schools in developing countries (chapter 3 ) is supposed to compensate for this weakness. In the evaluation of CBE programme, the students' feedback. 
the health workers' opinions and the community's reactions are the variables studied. ${ }^{15}$ In chapters 4 and 5, the evaluation study in MFDU only focuses on the intended curriculum, the students' activities, and the students opinions. Not assessing the community's perspectives is considered a limitation of this study. Recorded opinions of community representatives on MFDU's unmodified CBE programme (chapter 6) compensate for this lack of information. However, another limitation concerning the study presented in chapter 6 , is our failure to address opinions of supervisors and heads of PHC centres. Lastly, several aspects of the generic CBE objectives could not be addressed in this thesis and need to be tested in the field. For instance, in relation to community access to health services, the study presented in chapter 6 could not fully cover this issue.

\section{CONCLUSIONS}

Despite the limitations described above and in the respective chapters, we conclude that it proved possible to develop a framework for the definition of generic objectives for CBE programmes for undergraduate medical students in the developing world. Departing from factors impacting on community health, a list of generic objectives for $\mathrm{CBE}$ programmes was derived in a four-step approach. Accordingly, the final set of generic CBE objectives should have value for many medical schools in the developing world.

The combination of an established model for curriculum evaluation and the $C B E$ generic objectives as a reference can provide detailed insight in existing $C B E$ programmes. The results of the study should be used to increase the awareness of other institutions to regularly evaluate their CBE programmes, and medical schools in developing countries are suggested to use a similar approach. 
The application of the generic CBE objectives in the context of rural communities in Java, Indonesia, yielded active community participation and positive evaluations by students and community representatives. It is presumed that the application of the generic objectives for CBE is applicable in any developing country setting.

\section{What should CBE programmes be?}

The general objective of CBE programmes is to facilitate the students to have experience of community health problems and thereby to improve the health of the community. ${ }^{5}$ Thus, the essence of all CBE activities should be adjusted to these main goals, which implies that $\mathrm{CBE}$ programmes should be beneficial for both students and the community. ${ }^{3}$ Student exposure to a community must be started early and must be continuous during medical education. ${ }^{5}$ This will also facilitate the continuity of the health programmes implemented in the community. Educational objectives are needed both by the supervisor and the students including the steps that students should follow to meet those objectives. Moreover, student assessment in community settings is an important aspect to ensure the students` learning impact through the application of appropriate and relevant methods of assessment. ${ }^{2}$

In CBE programmes, close coordination between university, health care delivery system, local government and community is essential. Furthermore, the educational institution should set apart adequate resources to conduct the programme, or collaborate with social organisations to support the funding. ${ }^{8}$ Dedicated supervisors both from university or health services should be chosen, trained appropriately and attention should be paid not only to their funding but also to their careers. Encouraging community-based research as suggested by Joseph \& Abraham (2003) is useful to promote those careers. ${ }^{8}$ Community health workers and health providers should also be given attention to sustain their motivated participation in CBE. 
When students are posted in PHC centres or rural hospitals, students not only learn clinical skills and about the referral system, but also about many aspects related to community access to health services. Moreover, students should learn to apply a comprehensive approach such as family medicine when caring for patients, which includes home visits, health promotion and disease prevention.

When students are posted in the community, active community participation in identifying and addressing priority health problems is critical for the success and sustainability of their CBE programme. Community motivation to change the lifestyle or to participate in a community health activity is closely linked with their values, beliefs, and perceived needs. ${ }^{18}$ Active community participation ensures sustainability of community-based activities and provides political and moral support for the training institute..$^{15}$ Another strategy to sustain the CBE programme is e.g. involving several different locations to avoid community exhaustion. Last but not least: systematic programme evaluation should be planned and designed when setting up the CBE programme. 4.13

\section{The implications of this thesis in relation to the practice of $C B E$ and} to research

The results of our studies have important implications for the planning. implementation, and evaluation of CBE programmes. CBE curriculum planners need to critically assess the CBE objectives currently used to promote student activities, and they should reconsider the effective use of key resources, i.e. human resources, health services, and the community. Studies as presented in chapters 4, 5, and 6 of this thesis showed that the "top down" dictated government health programmes which were dominated by community diagnoses without any continuity, resulted in 
community exhaustion. Further work on the integration of top down and bottom up programmes is valuable, as it makes CBE programmes more beneficial for the community. Besides, the students will also learn to see the possible disparity between a government's health agenda and the health needs of society. ${ }^{23}$

The CBE programme should link at an appropriate time in the curriculum theory and practical experiences gained in the community. In line with our studies presented in chapter 5 and 6, Lennox and Petersen (1998) reported that students in their CBE programme felt too pressurised because of the restricted time available. This lack of time limited the potential benefit of their experiences. ${ }^{24}$ Further work is needed on the planning of CBE programmes in medical curricula, including adjustment of the time span of the CBE programme to the students" workload.

The evaluation of innovation in health professions education commonly concentrates on the effects on students and teachers, with few attention paid to effects on practice patterns and on community health. ${ }^{18}$ The study presented in chapter 6 only measured the impact of MFDU's $\mathrm{CBE}$ programmes on students and the community. Further research is needed to investigate the impact of $\mathrm{CBE}$ programme on health care delivery and the extent to which the educational institutions have assumed responsibility for meeting community needs and expectations. ${ }^{18}$ There are several areas that can be addressed e.g. access to health services, quality assurance of health services, consumer satisfaction with health services, allocation of resources, community participation in interventions, appropriate use of technology, distribution of health personnel, and improvement of community health. There is also a need for further evaluation of the effect of $\mathrm{CBE}$ programme on the willingness of graduates to serve in rural and medically underserved communities. ${ }^{25}$ 


\section{REFERENCES}

1. Magzoub ME, Schmidt HG. A taxonomy of community based medical education Academic Medicine 2000;75 (7):699-707.

2. Hamad B. What is community-based education? Evolution, definition and rationale. In: Schmidt HG, Magzoub M, Felleti G, Nooman $Z$, V'luggen $P$, eds. Handbook of Community-Based Education: Theory and Practices. Maastricht: Network Publications 2000;11-26.

3. World Health Organisation. Community-Based Education of Health Personnel. [WHO Study Group Report] Geneva: WHO 1987.

4. Margolis CZ. Community-based medical education. Medical Teacher 2000;22: 482-484.

5. Feletti G, Ja'afar R, Joseph A, Magzoub M, McHarney-Brown C, Omonisi K, Refaat A, Wachs J, Schmidt H. Implementation of Community-Based Curricula. In: Schmidt HG, Magzoub M, Feletti G, Nooman Z, Vluggen P, Eds. Handbook of Community-Based Education: Theory and Practices. Maastricht: Network Publications 2000;147-199

6. Brobby GW, Ofuso-Barko FO. Developing appropriate community-based postgraduate training in a developing country. Education for health. 2002;15:3-9.

7. Goh LG, Azwar A, Wonodirekso S. Managing the family medicine practice. In: Goh LG, Azwar A, Wonodirekso S, eds. A primer on family medicine practice. Singapore: Singapore International Foundation 2004;77-110.

8. Joseph A, Abraham S. Making community-based education programs sustainable? Education for Health 2003;16:129-132.

9. Murray $E$, Jolly B, Modell M. Can students learn clinical methods in general practice? A randomised crossover trial based on objective structured clinical examinations. British Medical Journal 1997;315:920-923

10. Magzoub ME. Studies in Community-based Education. Program Implementation and Student Assessment at the Faculty of Medicine, University of Gezira, Sudan. Thesis, Maastricht;1994

11. Kristina TN, Majoor GD, Van der Vleuten CPM. Defining generic objectives for community-based education in undergraduate medical programmes. Medical Education 2004;38:510-521.

12. Magzoub M.E, Schmidt HG, Abdel-Hameed AA, Dolmans D, Mustafa SE. Student assessment in community settings: A comprehensive approach. 
Medical Education 1998;32:50-59.

13. Kalishman $\mathrm{S}$. Evaluating community-based health professions education programs. Education for Health 2002; 15: 228-240.

14. Williams RL, Reid SJ, Myen C, Pitt L, Solarsh G. Practical skills and valued community outcomes: The next step in community-based education. Medical Education 1999;33:730-737.

15. Musal B. Aksakoglu G, Uçku R. Community-based education programme of Dokuz Eylui School of Medicine. Education for Health 2003;16:218-221.

16. Nazareth I. Mfenyana K. Medical education in the community - the UNITRA experience. Medical education 1999;33:722-724.

17. Blumenthal DS, Jones A, McNeal M. Evaluating a community-based multi professional course in community Health Edwcation for Health 2001:14: 251255.

18. World Health Organisation. Increasing the relevance of education for health professionals. [WHO Study Group Report] Geneva: WHO 1993

19. Ezzat $E$. Role of the community in contemporary health professions education. Medical Education 1995;29 (suppl.1):44-52.

20. Wilkinson JR, Murray SA. Assessment in primary care: practical issues and possible approaches. Brifish Medical Journal 1998;316:1524-1528.

21. Omotara BA, Padonu MKO, Bassi AP, Amodu MO. Attitude to communitybased rural posting and specialty preference. Annals of Community-Oriented Education 1992:5:33-40.

22. Wolff M, Maurana CA. Building effective community academic partnerships to improve health: a qualitative study of perspectives from communities. Academic Medicine 2001:76:166-72.

23. Worley $P$ Relationships: $A$ new way to analyse community-based medical education? (Part One). Education for Healh 2002:15:117-118.

24. Lennox A. Petersen S. Development and evaluation of a community based, multi agency course for medical students: Descriptive survey. Bititish Medical Journal 1998;316:596-599

25. Jinadu $M K$, Ojofeitimi $E O$, Oribabor $P$. Evaluation of an innovative approach to community-based medical undergraduate education in Nigeria Education for Health 2002;15:139 -148Magzoub ME. Schmidt HG. A taxonomy of community based medical education. Academic Medicine 2000:75 (7):699707. 


\section{Chapter 8}

\section{Summary}

Many medical schools all over the world strive to strengthen communityorientation of their curricula by implementing community-based education (CBE) programmes. The general objective of the CBE programme is to expand the students' experience in terms of learning. service and research in the community and thereby to improve the health of the community in which the programme is carried out. Although objectives for such CBE programmes must be tuned to local circumstances, the availability of a set of generic objectives for $\mathrm{CBE}$ programmes would assist medical schools in designing $C B E$ programmes or to compare the objectives of their own CBE programmes with to check whether all-important aspects were covered.

In chapter 1 , an overview is given with respect to the definition. background and rationale of CBE programmes, and a rationale for the definition of generic $\mathrm{CBE}$ objectives. Accordingly, this thesis focuses on the definition and validation of generic $\mathrm{CBE}$ objectives for undergraduate medical education in developing countries. The conceptual framework designed to derive generic CBE objectives was used as a reference to evaluate an existing CBE programme and as guidance in the design of a modified $\mathrm{CBE}$ programme closely matching the generic $\mathrm{CBE}$ objectives.

\section{Four major research questions are addressed in this thesis:}

1. How to develop a framework for the generation of generic CBE objectives for undergraduate medical programmes?

2. What is the perception of medical schools in developing countries toward the developed generic CBE objectives? Will the 
result of this study yield a validated list of $\mathrm{CBE}$ objectives for undergraduate medical training?

3. Can an established method of curriculum evaluation, combined with the generic CBE objectives for undergraduate medical programmes, be used as a reference for CBE programme evaluation?

4. What is the impact of a CBE programme matching the generic CBE objectives on students and the community?

In chapter 2, based on literature reviews and exploration of Internet sources, a four-step approach was used for the development of the generic CBE objectives for undergraduate medical programme. First, factors affecting community health that may be improved by the community itself in collaboration with students were identified i.e. the availability of safe drinking water, safe sanitation and healthy housing, adequate nutrition, rewarding daily activities, education on health risks, and access to health services. Second, potential student activities in CBE programmes to improve inadequate circumstances were defined and clustered as co-operation with the community in identifying and solving community health problems, performing health education, and conducting research activities that may indirectly contribute to the improvement of community access to health services. Third, competencies required in students to execute their possible tasks were defined and clustered according to three distinguished areas of CBE. i.e. research, training, and service. Fourth, 21 generic objectives for $\mathrm{CBE}$ programmes were formulated to develop those competencies in the students.

An international panel of 6 experts on CBE performed face validation of the draft framework. This study indicated that the generic $\mathrm{CBE}$ objectives could be beneficial for both students and the community 
and should encourage active community participation, which is in line with the recommendations for the implementation of CBE programme as advocated by the World Health Organization.

In chapter 3, a questionnaire survey was conducted among 72 medical schools in developing countries to validate the generic CBE objectives. The approach to develop the generic CBE objectives and $17 / 21$ items of these objectives were perceived as relevant. Three objectives were scored as relevant by less than $75 \%$ of the respondents (i.e. graduates have knowledge on occupation health; are able to monitor effectiveness and efficiency of community health services; and are able to invent realistic strategies to improve community access to health services) but were retained based on positive comments by respondents and support in the literature. One objective (i.e. graduates are able to manage a primary care unit and to sustain health administration) scored relevant by only $62.5 \%$ of the respondents and frequently criticised in added comments was deleted. As a result, this study yielded a validated list of 20 generic objectives for CBE in undergraduate medical training.

In chapters 4 and 5 , as a case study the 12-week CBE programme of the Medical Faculty of Diponegoro. University (MFDU) in Semarang, Indonesia. was evaluated. The curriculum evaluation model of Coles \& Grant was adopted for this study and hence subsequently the curriculum on paper, the curriculum in action, and the curriculum as experienced by the students were evaluated. The generic CBE objectives developed by us were used as a reference in the analysis of MFDU's CBE programme. The result of this study showed that MFDU has created adequate partnerships with the regional health care system and local authorities to enable CBE programmes to be implemented. However, some findings indicated 
that this programme was not entirely implemented as planned. The use of the set of generic $\mathrm{CBE}$ objectives as a reference revealed significant weaknesses of MFDU's CBE programme. For example, students' work in the community was not based on joint identification of felt health needs with community members, and students' interventions in the community were rarely evaluated. In general the students confirmed our conclusions and specifically emphasised community exhaustion and greater benefits of the CBE programme for the PHC centres and themselves than for the target communities. In conclusion, the curriculum evaluation model of Coles \& Grant combined with the generic CBE objectives for undergraduate medical programmes was found to be a useful tool to evaluate a CBE programme. However, further research is needed to test this evaluation model in other institutions.

In chapter 6, a non-blinded randomised trials was applied to compare a part of MFDU's conventional CBE programme with a programme modified to match the generic CBE objectives as closely as possible. As usual, students in the conventional programme received assignments to execute government health programmes from the head of the PHC centre. In the modified programme, the students used our framework and the derived generic CBE objectives as guidance for their activities, thus starting from the community's felt health needs. When compared with the unmodified programme, the modified programme yielded better student appreciation, better student performance, and high community compliance with the implemented health interventions. Representatives of communities that had experienced the modified programme expressed their satisfaction with the students' activities and recommended the same activities for future groups in other places. On the other hand, communities that hosted the unmodified programme felt 
that their health needs were hardiy discussed and addressed. They also criticised the students' activities for being too much focused on data collection. Thus, it can be concluded that substitution of a CBE programme that closely matched the generic CBE objectives resulted in more active community participation and a more positive evaluation by students and community representatives.

In chapter 7, all findings are discussed. With respect to the development of the generic CBE objectives, we discussed the strength of this study, which lies in the logical sequence of the four steps taken to yield objectives traceably rooted in factors impacting on community health. The weakness of this study is that the face validity of the framework and the derived objectives by an international expert panel was assessed only once. To compensate for this limitation a questionnaire survey was performed to acquire the perceptions of a wider circle of medical schools in developing countries. In this survey, more than $90 \%$ respondents had implemented CBE programmes. Therefore. their comments and suggestion were considered worthwhile in the finalisation of the generic CBE objectives. However, further study is needed to assess the importance of four objectives that were scored as relevant by less than $75 \%$ of the respondents.

In the study to test the usefulness of Coles and Grant' model for curriculum evaluation combined with the generic objectives as a reference for evaluation of CBE programmes, we are aware that no information from community representatives was included. If possible, we recommend to include that information when evaluating a $\mathrm{CBE}$ programme in action'. In the study performed to measure the impact of a CBE programme closely matching the generic CBE objectives on students and the community, we realise that the positive results obtained in this study are partly due to the shortcomings in the unmodified 
programme. Therefore, the generic CBE objectives should also be implemented in other medical schools to corroborate the reliability and generalisability of this study.

The results of the studies presented in chapters 2-6 have important implications for curriculum planning, implementation, and evaluation of CBE programmes, and directions are given for future studies on more specific conditions for CBE programmes in developing countries. $\mathrm{CBE}$ curriculum planners need to critically assess the CBE objectives that are currently used to promote student activities, and they should reconsider the effective use of key resources i.e. human resources, health services, and the community. Further work on the implementation of CBE programmes, which emphasise the integration of government health programmes with community's felt health needs is valuable, as it makes CBE programmes more beneficial for the community. In the evaluation of $\mathrm{CBE}$ programmes, measuring the impact of $\mathrm{CBE}$ programmes on health care delivery and the health of population is especially needed. Finally, studies are needed that addresses the willingness of medical graduates who were exposed to CBE programmes to serve as a professional in rural and medically underserved communities. 


\section{Samenvatting}

Overal ter wereld streven geneeskundefaculteiten ernaar om de maatschappelijke component van hun onderwijsprogramma te versterken door middel van gemeenschapsgericht onderwijs (GGO). De algemene doelstelling van dit onderwijs is on studenten ervaring te laten opdoen met leren, zorgverlening en onderzoek in de gemeenschap en op die manier een bijdrage te leveren aan de verbetering van de gezondheidssituatie in de gemeenschap waar het GGO-programma gevolgd wordt. Hoewel het belangrijk is dat de doelstellingen van $\mathrm{GGO}$ toegesneden zijn op de lokale situatie, zouden algemene doelstellingen van GGO zinvol kunnen zijn om medische faculteiten te helpen bij het ontwikkelen van GGO-programma's en om na te kunnen gaan of alle belangrijk aspecten van GGO in een programma zijn vertegenwoordigd.

In hoofdstuk 1 wordt ingegaan op de omschrijving, achtergrond en onderliggende principes van GGO en worden de ideeën uiteengezet. waarop de algemene doelstellingen van GGO gebaseerd zijn. Het centrale thema van dit proefschrift is de ontwikkeling en validering van algemene doclstellingen van GGO voor de medische basisopleiding in ontwikkelingslanden. Het ontwikkelde conceptuele kader voor de ontwikkeling van deze algemene doelstellingen vormt het referentiekader voor de evaluatie van een bestaand GGO-programma en de ontwikkeling van een aangepast GGO-programma dat nauw aansluit bij de algemene doelstellingen.

\section{Vier onderzoeksvragen zijn bestudeerd:}

1. Hoe kan een kader gecreëerd worden voor het ontwikkelen van algemene doelstellingen van GGO voor de medische basisopleiding? 
2. Hoe beoordelen medische faculteiten in ontwikkelingslanden de ontwikkelde algemene doelstellingen van GGO? Leiden de resultaten van dit onderzoek tot gevalideerde doelstellingen van GGO voor de medische basisopleiding?

3. Is een bestaande methode voor curriculumevaluatie in combinatie met de algemene doelstellingen van GGO voor de medische basisopleiding bruikbaar als referentiekader voor het evalueren van een GGO-programma?

4. Wat is de invloed op studenten en de gemeenschap van een GGO-programma dat is opgesteld conform de ontwikkelde algemene doelstellingen van $\mathrm{GGO}$ ?

In hoofdstuk 2 wordt een onderzoek beschreven waarin met behulp van overzichtsartikelen en internetbronnen in vier stappen algemene doelstellingen van GGO zijn ontwikkeld voor de medische basisopleiding. Als eerste stap is nagegaan voor welke van de factoren die bepalend zijn voor de locale gezondheidssituatie verbetering bereikt kan worden door middel van samenwerking tussen studenten en de lokale gemeenschap. Dit betreft factoren als schoon drinkwater, goede afvalverwerking, huisvesting, voeding, zinvolle dagelijkse bezigheden, voorlichting over gezondheidsrisico"s en toegang tot gezondheidszorg. Als tweede stap is bepaald welke activiteiten studenten in het kader van GGO kunnen uitvoeren ter verbetering van gebrekkige lokale omstandigheden. Deze activiteiten zijn samengevat in de clusters samenwerking met de lokale gemeenschap bij het opsporen en aanpakken van lokale gezondheidsproblemen', "het geven van gezondheidsvoorlichting" en "het doen van onderzoek dat indirect kan bijdragen aan een betere bereikbaarheid van gezondheidszorgvoorzieningen voor de lokale gemeenschap'. Als derde stap is bepaald over welke competenties studenten moeten beschikken om deze taken uit te kunnen voeren. Drie competentieclusters werden 
onderscheiden overeenkomstig de drie GGO-domeinen: onderzoek, onderwijs en zorg. De vierde stap bestond uit het formuleren van algemene doelstellingen van GGO, die kunnen bevorderen dat studenten deze competenties verwerven.

Een internationaal panel bestaand uit zes GGO-experts onderzocht de "face validity" van het conceptkader voor de algemene doelstellingen. Dit onderzoek wees uit dat zowel de studenten als de gemeenschap profijt kunnen hebben van algemene doelstellingen van GGO en dat deze doeistellingen actieve betrokkenheid van de gemeenschap kunnen bevorderen. Dit is in overeenstemming met aanbevelingen van de Wereldgezondheidsorganisatie voor het opzetten van GGO-programma“s.

In hoofdstuk 3 wordt gerapporteerd over een onderzoek waarbij een vragenlijst is afgenomen bij 72 geneeskundeopleidingen in ontwikkelingslanden teneinde de algemene doelstellingen van GGO te valideren. De methode voor het ontwikkelen van de doelstellingen van GGO en 17 van de 21 doelstellingen werden als relevant beoordeeld. Drie doelstellingen werden door minder dan $75 \%$ van de respondenten als relevant beoordeeld: afgestudeerden beschikken over kennis op het gebied van de arbeidsgeneeskunde, kunnen de effectiviteit en de doelmatigheid van lokale gezondheidszorgvoorzieningen controleren en kunnen praktische strategieën ontwikkelen om toegang tot gezondheidszorg voor de lokale bevolking te verbeteren. Toch zijn deze doelstellingen gehandhaafd, omdat er positieve commentaren van respondenten waren en omdat er steun voor gevonden werd in de literatuur. Eén doelstelling - afgestudeerden kunnen een post voor eerstelijns gezondheidszorg leiden en beheren - werd door slechts $62,5 \%$ van de respondenten als relevant beoordeeld en was meermalen onderwerp van kritiek in aanvullende opmerkingen. Deze doelstelling is dan ook verwijderd. Het onderzoek resulteerde in een gevalideerde lijst 
van 20 algemene doelstellingen van GGO voor de medische basisopleiding.

Hoofdstuk 4 en 5 betreffen een onderzoek waarin als casus het traditionele drie maanden durende GGO-programma van de Medische Faculteit van de Diponegoro Universiteit (MFDU) in Semarang, Indonesië geëvalueerd is. Voor de evaluatie is het model van Coles en Grant gebruikt. Dit betekent dat het 'curriculum-op-papier', het 'curriculum-in-de-praktijk' en het 'curriculum-zoals-de-studenten-hetervaren" geëvalueerd zijn. De door ons ontwikkelde algemene doelstellingen wan GGO vormden het referentiekader voor de analyse van het GGO-programma van de MFDU. Uit de resultaten van dit onderzoek kwam naar voren dat de samenwerking tussen de MFDU en de regionale gezondheidszorg en de plaatselijke autoriteiten voldoende was om GGO-programma's te kunnen uitvoeren. Er waren echter enkele bevindingen die een aanwijzing vormden dat het programma niet helemaal volgens de planning verliep. Met behulp van de algemene doelstellingen van GGO konden belangrijke zwakke punten in het GGO van de MFDU aan het licht gebracht worden. Zo was het werk van de studenten in de lokale gemeenschap niet gebaseerd op gezondheidsbehoeften die in samenwerking met leden van de lokale gemeenschap waren vastgesteld en werden de interventies van de studenten in de gemeenschap slechts zelden geëvalueerd. Onze conclusies werden algemeen door de studenten bevestigd. met name de bevinding dat de gemeenschap genoeg kreeg van het programma en het feit dat het programma meer ten goede kwam aan de gezondheidscentra en de studenten dan aan de lokale doelgroepen. Ten slotte bleek dat de combinatie van het curriculumevaluatiemodel van Coles en Grant met de algemene doelstellingen van GGO voor de medische basisopleiding een goed evaluatie-instrument opleverde voor een GGO-programma. Wel is meer onderzoek nodig om de waarde van dit evaluatiemodel te toetsen in andere instellingen. 
In hoofdstuk 6 wordt verslag gedaan van een niet-geblindeerd gerandomiseerd onderzoek waarin een deel van het traditionele $\mathrm{GGO}$ programma van de MFDU vergeleken is met een aangepast programma dat zoveel mogelijk aansloot op de ontwikkelde algemene doelstellingen van GGO. De studenten die het traditionele programma volgden, kregen op de gebruikelijke wijze opdrachten van het hoofd van het gezondheidszorgcentrum, gericht op het uitvoeren wan gezondheidszorgprogramma's van de regering. In het aangepaste programma werden de activiteiten van de studenten ontwikkeld op basis van ons kader en de daaraan ontleende algemene doelstellingen van GGO. Dit betekende dat de activiteiten aansloten bij de gezondheidsbehoeften die leefden in de lokale gemeenschap. Vergeleken met het ongewijzigde programma kreeg het aangepaste programma meer waardering wan de studenten, leidde het tot betere prestaties van de studenten en tot een hoge mate van blijvende lokale medewerking ten aanzien van de ingevoerde gezondheidsmaatregelen. Vertegenwoordigers van de gemeenschappen waar het aangepaste programma werd uitgevoerd, spraken hun tevredenheid uit over de activiteiten van de studenten en deden de aanbeveling om dezelfde activiteiten door nieuwe groepen op andere plaatsen te laten uitvoeren. Daarentegen gaven de gemeenschappen waar het ongewijzigde programma was uitgevoerd, te kennen dat zij het gevoel hadden dat hun gezondheidszorgbehoeften nauwelijks ter sprake waren gekomen en dat er ook bijna niets gedaan werd om aan hun behoeften tegemoet te komen. Een ander punt van kritiek was dat de activiteiten van de studenten te veel gericht waren op het verzamelen van gegevens. Er kan dus geconcludeerd worden dat de invoering van een GGO-programma dat naww aansloot bij de algemene doelstellingen van GGO leidde tot actievere betrokkenheid van de lokale gemeenschap en een positievere beoordeling door zowel studenten als vertegenwoordigers van de gemeenschap. 
In hoofdstuk 7 worden alle resultaten besproken. We bespreken de kracht wan dit onderzoek met betrekking tot de ontwikkeling van algemene doelstellingen van $\mathrm{GGO}$, die gelegen is in de logische opeenvolging van de vier stappen die resulteren in doelstellingen die aantoonbaar geworteld zijn in factoren die bepalend zijn voor de lokale gezondheidssituatie. Een zwak punt van dit onderzoek is dat de "face validity' van het kader en de daaruit afgeleide doelstellingen slechts eenmaal door een panel van internationale experts is beoordeeld. Ter compensatie voor deze beperking is een enquete gehouden onder een brede groep geneeskundeopleidingen in ontwikkelingslanden. Meer dan $90 \%$ van de respondenten hadden eigen GGO-programma`s. Hun commentaren en voorstellen werden dan ook als een waardevolle bijdrage gezien aan de definitieve versie van de algemene doelstellingen van GGO. Nader onderzoek zal inzicht moeten bieden in het belang van de vier doelstellingen die door minder dan $75 \%$ van de respondenten als relevant werden beoordeeld. We zijn ons ervan bewust dat er in het onderzoek naar de bruikbaarheid van de combinatie van het curriculumevaluatiemodel van Coles en Grant en de algemene doelstellingen van GGO als referentiekader voor de evaluatie van GGO geen rekening is gehouden met de inbreng van vertegenwoordigers van lokale gemeenschappen. Het is aan te bevelen om, indien mogelijk. deze informatie te betrekken bij de evaluatie van 'GGO-programma's-in-depraktijk". Wij zijn ons er ook van bewust dat de positieve bevindingen uit het onderzoek naar de invloed op studenten en de lokale gemeenschap van een GGO-programma dat nauw aansluit bij de algemene doelstellingen van GGO deels zijn toe te schrijven aan de tekortkomingen van het ongewijzigde traditionele programma. Het is daarom aan te bevelen dat de algemene doelstellingen van GGO ook toegepast worden door andere geneeskundeopleidingen, opdat de betrouwbaarheid en generaliseerbaarheid van de resultaten van ons onderzoek bevestigd kunnen worden. De resultaten van de onderzoeken 
die beschreven worden in hoofdstuk 2-6, hebben belangrijke implicaties voor de planning, uitvoering en evaluatie van GGO-programma*s. Er wordt gewezen op de noodzaak van nader onderzoek naar specifiekere voorwaarden voor GGO-programma's in ontwikkelingslanden. Curriculumplanners die GGO-programma's ontwikkelen, moeten de huidige doelstellingen van GGO, op grond waarvan bepaald wordt welke activiteiten studenten ondernemen, kritisch beoordelen en zij moeten tevens aandacht besteden aan het doelmatig benutten van belangrijke bronnen, zoals menselijk kapitaal, gezondheidszorginstellingen en de gemeenschap. Verdere inspanningen om GGO-programma's in te voeren die de nadruk leggen op integratie van gezondheidszorgprogramma 5 van de regering met de gezondheidsbehoeften van lokale gemeenschappen zijn belangrijk, omdat dit ertoe leidt dat de gemeenschap meer profijt heeft van GGO-programma's. Bij de evaluatie van GGO-programma's moet de nadruk vooral gelegd worden op de effecten van GGOprogramma's op het gezondheidszorgaanbod en de gezondheidstoestand van de bevolking. Tot slot wijzen wij op de noodzaak van onderzoek naar de bereidheid van afgestudeerde artsen die GGO-programma"s gevolgd hebben om op het platteland en in gemeenschappen met gebrekkige gezondheidszorgvoorzieningen te gaan werken. 


\section{Ringkasan}

Banyak fakultas-fakultas kedokteran di dunia berusaha untuk memperkuat kurikulumnya agar lebih berorientasi terhadap mayarakat dengan cara mengimplementasikan program pendidikan berbasis masyarakat (PBM). Tujuan umum dari program ini adalah untuk memperluas pengalaman dari mahasiswa dalam hal pembelajaran, pelayanan serta penelitian di masarakat. Sehingga dengan cara demikian akan meningkatkan kesehatan masyarakat dimana program ini dilaksanakan. Meskipun tujuan dari program pendidikan ini harus disesuarkan dengan keadaan setempat (loka)), tersedianya suatu kumpulan tujuan umum dari program PBM ini akan dapat membantu fakultas kedokteran dalam mendesain program ini, atau membandingkan dengan program mereka sendiri apakah sudah imencakup aspek-aspek yang terpenting.

Pada bab 1, gambaran dari program PBM ini diberikan dalam hal definisi, latar belakang dan dasar-dasar rasionalnya. Juga alasan untuk menetapkan tujuan umum PBM pada program pendidikan dokter. Sesuai dengan itu, maka tesis ini difokuskan untuk menetapkan dan mengesahkan tujuan umum untuk program pendidikan dokter di negara-negara berkembang. Kerangka kerja dari tujuan umum program PBM ini di tes sebagai acuan dalam mengevaluasi program PBM yang telah ada, dan sebagai panduan dalam mendesain program PBM agar sesuai dengan tujuan umum PBM.

\section{Empat pertanyaan utama penelitian dalam tesis ini adalah sbb:}

1. Bagaimana cara mengembangkan kerangka kerja untuk menetapkan definisi dari tujuan umum PBM pada program pendidikan dokter? 
2. Apakah persepsi dari fakultas-fakultas kedokteran di negaranegara berkembang terhadap tujuan umum program PBM? Dapatkah hasil penelitian ini dipakai untuk mensahkan daftar tujuan umum PBM untuk pendidikan dokter?

3. Dapatkah metode yang baku untuk mengevaluasi kurikulum dikombinasikan dengan tujuan umum PBM untuk program dokter dipakai sebagai acuan dalam mengevaluasi program PBM ?

4. Apakah pengaruh dari program PBM yang telah disesuaikan dengan tujuan umum PBM tersebut bagi mahasiswa dan masyarakat?

Pada bab 2, berdasarkan tinjauan kepustakaan dan explorasi sumber-sumber dari Internet, digunakan empat strategi sebagai pendekatan untuk mengembangkan tujuan umum PBM untuk program pendidikan dokter. Pertama, faktor-faktor yang mempengaruhi kesehatan masyarakat yang mungkin dapat ditingkatkan oleh masyarakat sendiri dengan bekerja sama dengan mahasiswa diidentifikasi, yaitu: tersedianya air minum yang aman, sanitasi dan rumah sehat, makanan yang adekwat, penghargaan yang pantas atas aktifitas sehari-hari, edukasi terhadap faktor resiko yang berpengaruh terhadap kesehatan, dan akses terhadap pelayanan kesehatan. Kedua, tugas-tugas yang potensial bagi mahàsiswa dalam melakukan aktifitas program PBM untuk meningkatkan keadaan yang tidak adekwat ditetapkan, dan dikelompokkan sebagai suatu kerja sama dengan masyarakat untuk mengidentifikasi dan mengatasi masalah kesehatan masyarakat, melakukan edukasi kesehatan, dan melakukan aktifitas penelitian yang secara tidak langsung mempunyai kontribusi terhadap peningkatan akses masyarakat pada pelayanan kesehatan. Ketiga, kompetensi yang diperlukan untuk melaksanakan tugas-tugas tersebut ditetapkan dan ditujukan pada 3 area dari PBM, yaitu: penelitian, pelatihan dan 
pelayanan. Keempat, 21 tujuan tumum program PBM diformulasikan untuk menghasilkan kompetensi-kompetensi tersebut.

Diskusi panel internasional yang diikuti oleh 6 pakar PBM dari institusinya masing-masing digunakan sebagai cara untuk mensahkan konsep yang telah dibuat. Studi ini mengindikasikan bahwa tujuan umum PBM harus berguna baik untuk mahasiswa maupun masyarakat, dan harus difokuskan pada partisipasi masyarakat yang aktif, dimana hal ini sangat sesuai dengan anjuran WHO dalam mengimplementasikan program PBM.

Pada bab 3, survai untuk mensahkan tujuan umum PBM dengan cara mendistribusikan kuesioner pada fakultas-fakultas kedokteran di negara-negara berkembang menunjukkan hasil yang memuaskan. Strategi untuk mengembangkan tujuan umum PBM, dan 17/21 itemnya dinyatakan relevan. Tiga tujuan dinilai relevan oleh kurang dari $75 \%$ responden (yaitu: lulusan mempunyai pengetahuan tentang kesehatan kerja, mempunyai kemampuan untuk memonitor efektifitas dan efisiensi pelayanan kesehatan, dan mempunyai kemampuan untuk mendesain strategi yang relevan untuk meningkatkan akses masyarakat terhadap pelayanan kesehatan) tetapi tetap dipertahankan atas dasar komentar yang positip dari responden, serta ditunjang oleh kepustakaan. Satu tujuan (yaitu: lulusan mempunyai kemampuan untuk memanage puskesmas dan administrasi) dihapus karena hanya dinilai relevan oleh $62.5 \%$ responden dan juga sering mendapat kritikan pada komentar tambahan. Sebagai hasilnya, penelitian ini menghasilkan 20 daftar tujuan umum PBM untuk program pendidikan dokter yang tervalidasi.

Pada bab 4 dan 5, sébagai studi kasus, dilakukan evaluasi program PBM di Fakultas Kedokteran Universitas Diponegoro, Semarang, Indonesia (FK. UNDIP). Model dari Cole \& Grant diadopsi untuk studi ini, dimana evaluasi dilakukan terhadap kurikulum di atas kertas, 
pellaksanaan kurikulum dan pengalaman mahasiswa pada kurikulum tersebut. Tujuan umum PBM yang sudah dikembangkan digunakan sebagai acuan dalam menganalisa program PBM di FK. UNDIP. Hasil dari studi ini menunjukkan bahwa FK.UNDIP sudah menghasilkan kemitraan yang adekwat dengan sistem pelayanan kesehatan dan pemerintah lokal sehingga program PBM ini dapat diimplementasikan. Meskipun demikian, beberapa penemuan menunjukkan bahwa program ini tidak seluruhnya diimplementasikan sesuai dengan yang direncanakan. Penggunaan tujuan umum PBM sebagai acuan menunjukkan beberapa kelemahan yang berarti dari program ini, misalnya: mahasiswa dalam mengidentifikasi masalah kesehatan tidak berdasarkan atas kerja sama dengan masyarakat, dan evaluasi terhadap hasil intervensi di masyarakat jarang dilakukan. Secara umum mahasiswa memperkuat kesimpulan ini dan menegaskan adanya kebosanan dari masyarakat, dan program PBM ini mempunyai manfaat yang lebih besar untuk puskesmas dan mahasiswa daripada untuk masyarakat. Sebagai kesimpulan, evaluasi kurikulum dengan menggunakan model dari Coles \& Grant dikombinasikan dengan tujuan umum PBM merupakan alat yang berguna untuk mengevaluasi program PBM. Meskipun demikian penelitian selanjutnya masih dibutuhkan untuk mentes model evaluasi ini pada institusi yang lain.

Pada bab 6, percobaan dengan sistem acak tidak membuta dilakukan untuk membandingkan sebagian dari program PBM di FK.UNDIP yang konvensional dengan yang telah dimodifikasi sehingga sesuai dengan tujuan umum PBM. Secara rutin, mahasiswa pada program yang konvensional menerima tugas dari kepala puskesmas untuk melaksanakan program kesehatan pemerintah. Pada program yang telah dimodifikasi, mahasiswa menggunakan kerangka kerja kami dan tujuan umum PBM, sehingga mereka harus memulai dari kebutuhan yang dirasakan oleh masyarakat. Ketika dibandingkan dengan program yang 
konvensional; hasil dari program yang dimodifikasi menunjukkan penghargaan dan prestasi yang lebih baik dari mahasiswa, dan kepatuhan yang tinggi dari masyarakat terhadap intervensi kesehatan yang diimplementasikan. Perwakillan masyarakat yang mengalami program yang telah dimodifikasi mengemukakan kepuasan mereka terhadap aktifitas mahasiswa dan menganjurkan aktifitas yang sama di tempat lainnya. Sebaliknya, perwakilan masyarakat yang ketempatan program konvensional merasa bahwa kebutuhan mereka jarang didiskusikan ataupun dipenuhi. Mereka juga mengkritik aktifitas mahasiswa yang hanya difokuskan pada pengumpulan data saja. Sebagai kesimpulan, penggantian program PBM dengan yang lebih sesuai dengan tujuan umum PBM yang menegaskan keterlibatan masyarakat menghasilkan partisipasi yang lebih aktif dari masyarakat dan evaluasi yang lebih positip baik oleh mahasiswa maupun masyarakat.

Pada bab 7, seluruh penemuan hasil studi didiskusikan. Sehubungan dengan definisi tujuan umum PBM, kami mendiskusikan tentang kekekuatan dari studi ini yang terletak pada urutan yang logis dari empat langkah yang diambil sehingga menghasilkan tujuan yang berakar dari faktor-faktor yang mempengaruhi kesehatan masyarakat. Kelemahan studi ini terletak pada validasi yang hanya dilakukan satu kali dengan cara diskusi panel dengan pakar internasional. Sehingga survey yang kemudian dilaksanakan untuk mendapatkan persepsi dari fakultas kedokteran di negara-negara berkembang diasumsikan untuk dapat mengkompensasi keterbatasan ini. Pada survai ini lebih dari $90 \%$ responden sudah mengimplementasikan dan berpengalaman dengan program PBM. Oleh karena itu, komentar dan nasehat mereka dapat dipertimbangkan sebagai sesuatu yang berguna dalam memfinalisasi tujuan umum PBM. Meskipun demikian studi selanjutnya masih diperlukan untuk mengklarifikasi 4 item yang dinilai relevan oleh kurang dari $75 \%$ responden. 
Pada studi untuk menguji kegunaan dari model Coles dan Grant dalam mengevaluasi kurikulum dikombinasikan dengan tujuan umum PBM sebagai acuan dalam mengevaluasi program PBM, kami menyadari tidak adanya informasi dari masyarakat yang mewakili. Sehingga bila memungkinkan, kami merekomendasikan untuk menambahkan informasi ini pada waktu mengevaluasi 'pelaksanaan kurikulum'.

Pada studi untuk mengetahui pengaruh dari program PBM yang telah disesuaikan dengan tujuan umum PBM pada mahasiswa maupun masyarakat, kami menyadari bahwa hasil yang positip dari studi ini sangat dipengaruhi oleh kelemahan dari program konvensional yang dimplementasikan dengan cara yang kurang tepat. Oleh karena itu, studi selanjutnya untuk mengimplementasikan tujuan umum ini pada institusi lain perlu dilakukan untuk memperkuat studi ini dalam hal pengulangan dan kepercayaan yang lebih luas.

Hasil-hasil studi yang dipresentasikan pada bab 2 sampai 6 mempunyai implikasi yang penting untuk perencanaan kurikulum. implementasi dan evaluasi program PBM, serta pengarahan diberikan untuk studi selanjutnya yang ditujukan pada kondisi yang lebih spesifik untuk program PBM di negara-negara berkembang. Perencana kurikulum harus menilai secara kritis tujuan PBM yang sedang digunakan untuk meningkatkan aktifitas mahasiswa, dan mereka juga harus mempertinbangkan kembali penggunaan sumber-sumber kunci yang efektif, yaitu sumber daya manusia, pelayanan kesehatan, dan masyarakat. Studi selanjutnya, yang menegaskan pada integrasi dari program kesehatan pemerintah dengan kebutuhan yang dirasakan oleh masyarakat perlu dilakukan karena dapat meningkatkan program PBM agar lebih berguna untuk masyarakat. Pada evaluasi program PBM, perlu dilakukan pengukuran pengaruh dari progam $\mathrm{PBM}$ pada pemberian pelayanan kesehatan dan juga kesehatan dari populasi penduduk. Akhirnya, studi 
selanjutnya juga diperlukan untuk mengetahui apakah lulusan yang sebelumnya telah di ekspose dengan program PBM mempunyai keinginan untuk bekerja di daerah rural maupun di masyarakat bawah. 


\section{Appendix}

\section{List of Abbreviation}

- ATLS : Advanced Trauma Life Support

- CBE : Community-based education

- COE : Community-oriented education

- DHF : Dengue Hemorrhage Fever

- FGD : Focus Group Discussion

- HFA : Health for All

- LLO : : International Labour Organization

- MFDU : Medical Faculty of Diponegoro University

- OSCE : objective structured clinical examination

- PHC centre : Primary Health Care centre.

- RHPTC : Rural Health Professions Training Centre

- TB : Tuberculosis

- TUFH : Towards Unity for Health

- WHO : World Health Organization 


\section{CBE activities in MFDU}

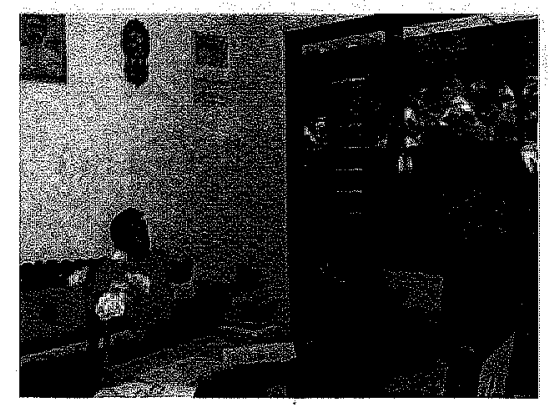

Interview community leader

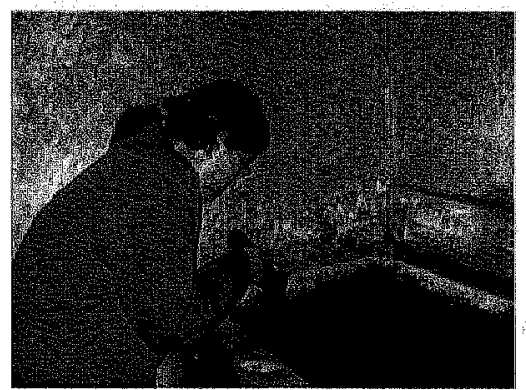

Risk assessment of DHF (Assessment of mosquito larva Aedes aegepty)

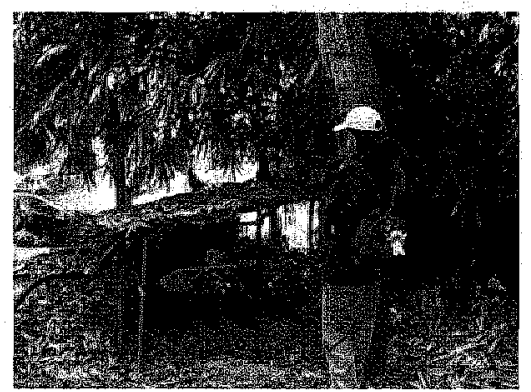

Risk assessment in relation to environment (Unhealthy sanitation)

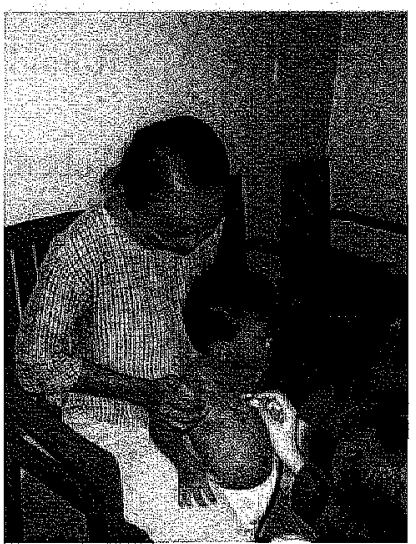

Malnutrition 


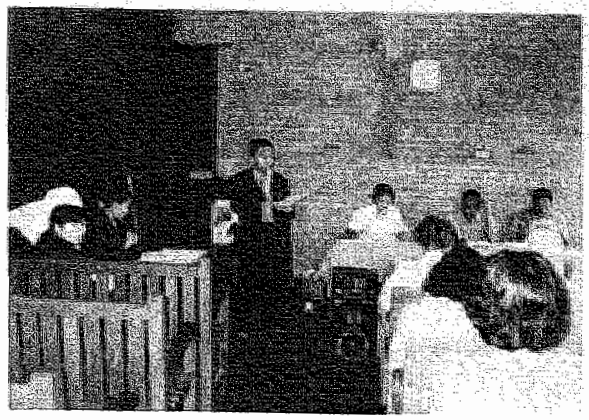

Discussion with community about health problem identified

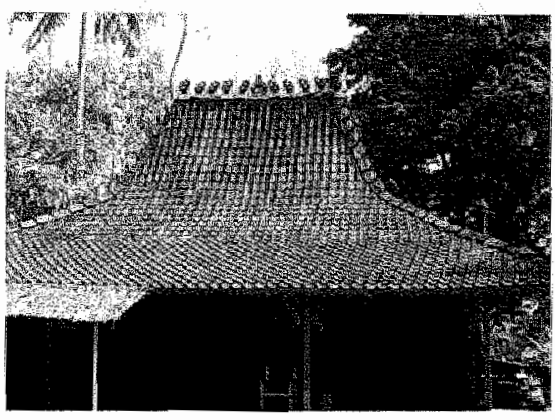

Dark (unhealthy) bouse

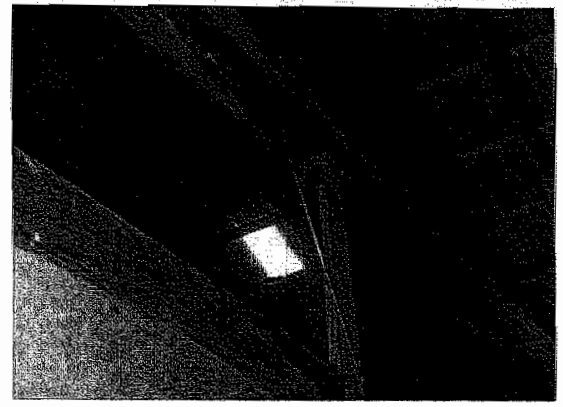

Glass roof

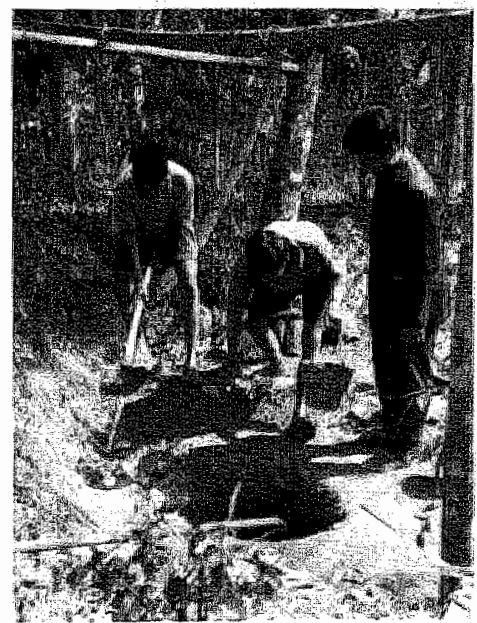

Assisst the community

to build public toilet 